\title{
Dry deposition of reactive nitrogen to European ecosystems: a comparison of inferential models across the NitroEurope network
}

\author{
C. R. Flechard ${ }^{1}$, E. Nemitz ${ }^{2}$, R. I. Smith ${ }^{2}$, D. Fowler ${ }^{2}$, A. T. Vermeulen ${ }^{3}$, A. Bleeker ${ }^{3}$, J. W. Erisman ${ }^{3}$, D. Simpson ${ }^{4,5}$, \\ L. Zhang ${ }^{6}$, Y. S. Tang ${ }^{2}$, and M. A. Sutton ${ }^{2}$ \\ ${ }^{1}$ INRA, Agrocampus Ouest, UMR 1069 SAS, Rennes, France \\ ${ }^{2}$ Center for Ecology and Hydrology (CEH) Edinburgh, Penicuik, UK \\ ${ }^{3}$ ECN, Netherlands Energy Research Foundation, Petten, The Netherlands \\ ${ }^{4}$ EMEP MSC-W, Norwegian Meteorological Institute, Norway \\ ${ }^{5}$ Department Earth \& Space Sciences, Chalmers University of Technology, Gothenburg, Sweden \\ ${ }^{6}$ Environment Canada, Toronto, Canada
}

Received: 28 October 2010 - Published in Atmos. Chem. Phys. Discuss.: 1 December 2010

Revised: 14 March 2011 - Accepted: 14 March 2011 - Published: 23 March 2011

\begin{abstract}
Inferential models have long been used to determine pollutant dry deposition to ecosystems from measurements of air concentrations and as part of national and regional atmospheric chemistry and transport models, and yet models still suffer very large uncertainties. An inferential network of 55 sites throughout Europe for atmospheric reactive nitrogen $\left(\mathrm{N}_{\mathrm{r}}\right)$ was established in 2007, providing ambient concentrations of gaseous $\mathrm{NH}_{3}, \mathrm{NO}_{2}, \mathrm{HNO}_{3}$ and $\mathrm{HONO}$ and aerosol $\mathrm{NH}_{4}^{+}$and $\mathrm{NO}_{3}^{-}$as part of the NitroEurope Integrated Project.

Network results providing modelled inorganic $\mathrm{N}_{\mathrm{r}}$ dry deposition to the 55 monitoring sites are presented, using four existing dry deposition routines, revealing inter-model differences and providing ensemble average deposition estimates. Dry deposition is generally largest over forests in regions with large ambient $\mathrm{NH}_{3}$ concentrations, exceeding $30-40 \mathrm{~kg} \mathrm{Nha}^{-1} \mathrm{yr}^{-1}$ over parts of the Netherlands and Belgium, while some remote forests in Scandinavia receive less than $2 \mathrm{~kg} \mathrm{Nha}^{-1} \mathrm{yr}^{-1}$. Turbulent $\mathrm{N}_{\mathrm{r}}$ deposition to short vegetation ecosystems is generally smaller than to forests due to reduced turbulent exchange, but also because $\mathrm{NH}_{3}$ inputs to fertilised, agricultural systems are limited by the presence of a substantial $\mathrm{NH}_{3}$ source in the vegetation, leading to periods of emission as well as deposition.

Differences between models reach a factor 2-3 and are often greater than differences between monitoring sites. For soluble $\mathrm{N}_{\mathrm{r}}$ gases such as $\mathrm{NH}_{3}$ and $\mathrm{HNO}_{3}$, the non-stomatal pathways are responsible for most of the annual uptake over many surfaces, especially the non-agricultural land uses,
\end{abstract}

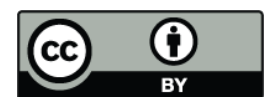

Correspondence to: C. R. Flechard (chris.flechard@ rennes.inra.fr) but parameterisations of the sink strength vary considerably among models. For aerosol $\mathrm{NH}_{4}^{+}$and $\mathrm{NO}_{3}^{-}$, discrepancies between theoretical models and field flux measurements lead to much uncertainty in dry deposition rates for fine particles $(0.1-0.5 \mu \mathrm{m})$. The validation of inferential models at the ecosystem scale is best achieved by comparison with direct long-term micrometeorological $\mathrm{N}_{\mathrm{r}}$ flux measurements, but too few such datasets are available, especially for $\mathrm{HNO}_{3}$ and aerosol $\mathrm{NH}_{4}^{+}$and $\mathrm{NO}_{3}^{-}$.

\section{Introduction}

The environmental effects of excess atmospheric reactive nitrogen $\left(\mathrm{N}_{\mathrm{r}}\right)$ deposition to terrestrial ecosystems include soil acidification, the eutrophication of water bodies, nutrient imbalances, the leaching of base cation and nitrate, loss of biodiversity, direct toxicity to plants, increased $\mathrm{N}_{2} \mathrm{O}$ emissions, and the inhibition of soil $\mathrm{CH}_{4}$ oxidation (Galloway et al., 2003; Erisman et al., 2007). Elevated $\mathrm{N}_{\mathrm{r}}$ deposition rates are the result of increased ambient concentrations due to increased emissions by intensive farming (mostly reduced $\mathrm{N}_{\mathrm{r}}$ ) and by traffic and industry (mostly oxidised $\mathrm{N}_{\mathrm{r}}$ ). A role of $\mathrm{N}_{\mathrm{r}}$ deposition as a strong driver of carbon sequestration by temperate and boreal forests has been suggested (Magnani et al., 2007) but the magnitude of the effect ( $\mathrm{kg} \mathrm{C}$ sequestered/kg N deposited) has been contested (de Vries et al., 2008; Sutton et al., 2008). Dry and wet deposition control the atmospheric life times and mean transport distances of $\mathrm{N}_{\mathrm{r}}$ species downwind from point and diffuse sources and therefore affect pollutant transport across borders. This is evaluated at the European scale within the framework of the

Published by Copernicus Publications on behalf of the European Geosciences Union. 
1979 Convention on Long Range Transboundary Air Pollution (CLRTAP) (UNECE, 1999, www.unece.org/env/lrtap/) and the associated European Monitoring and Evaluation Programme (EMEP, www.emep.int), using gas and particle concentration monitoring networks to validate atmospheric model simulations (e.g. Fagerli and Aas, 2008; Simpson et al., 2006a). In North America, the Canadian Air and Precipitation Monitoring Network (CAPMoN; http://www.ec. gc.ca/rs-mn/default.asp?lang=En\&n=752CE271-1 capmon) and the US Clean Air Status and Trends Network (CASTNet; http://www.epa.gov/castnet) have also been monitoring air concentrations for more than three decades.

The dry deposition of $\mathrm{N}_{\mathrm{r}}$, present in air in various inorganic species such as gaseous $\mathrm{NH}_{3}, \mathrm{HNO}_{3}, \mathrm{HONO}, \mathrm{NO}$, $\mathrm{NO}_{2}$ and aerosol $\mathrm{NH}_{4}^{+}$and $\mathrm{NO}_{3}^{-}$, as well as in a range of organic molecules in both phases (e.g. gaseous peroxyacetyl nitrate (PAN) and other organic nitrates, amines - see Ge et al., 2011), typically contributes between one third and two thirds of total atmospheric $\mathrm{N}$ deposition (Erisman et al., 1996; Simpson et al., 2006a; Zimmermann et al., 2006; Zhang et al., 2009). The partitioning between dry, wet and occult (i.e. cloud water) deposition depends on atmospheric gas and aerosol $\mathrm{N}_{\mathrm{r}}$ concentrations, weather patterns as well as land use/vegetation characteristics such as surface roughness, canopy leaf surface area and vegetation wetness. Unlike wet deposition, which is widely monitored in regional networks of wet-only or bulk precipitation collectors, measurements of dry (turbulent) $\mathrm{N}_{\mathrm{r}}$ exchange fluxes have largely remained experimental and limited to selected research sites and to measurement campaigns of typically a few days to a few months, due to technical complexity and to the large equipment and operational costs involved. $\mathrm{N}_{\mathrm{r}}$ concentration detectors that are reliable, sturdy, interference-free, fast and precise have proved elusive so far, at least as far as long-term micrometeorological flux measurements are concerned. Additional issues concerning inlet design, sampling losses and air column chemical reactions for highly reactive and soluble $\mathrm{N}_{\mathrm{r}}$ species further indicate that large-scale dry deposition monitoring networks remain as yet impracticable.

Inferential modelling has been used extensively as an operational tool to obviate the absence of measured dry deposition data at regional scales (Baumgardner et al., 2002; Sickles and Shadwick, 2007; Erisman et al., 2005; Zhang et al., 2009). The method was originally developed to assess ecosystem damage in areas subjected to acid (sulphur) deposition and to compute regional pollutant mass balances (e.g. Wesely and Hicks, 1977; Garland, 1977).

Dry deposition, or bi-directional surface/atmosphere exchange, may be inferred from the knowledge of (measured) atmospheric gaseous or particulate pollutant concentration above vegetation (or any roughness element at the Earth's surface), using various assumptions regarding transfer rates through the air and the surface. A number of increasingly complex inferential schemes have been implemented in atmospheric transport chemical models (Meyers et al., 1998;
Wesely and Hicks, 2000; Wu et al., 2003; Zhang et al., 2003), or are being proposed for implementation (Wu et al., 2009; Zhang et al., 2010; Massad et al., 2010 in the case of $\mathrm{NH}_{3}$ ), and these can also be used to interpret micrometeorological field flux measurements. These models have been parameterised on the basis of measured field flux data, but specific exchange processes and pathways are still poorly understood and their parameterisations remain crude and largely empirical. Also, model development has taken place in different countries or continents, with different land uses, atmospheric chemistry, climates, so that parameterisations derived from field data may not be universally valid. Model development and validation tended originally to happen in parallel and be selective (rather than inclusive) in the flux datasets that were used in support. This was partly due to the very complex and varied responses of ecosystems as receptors (or sources) of atmospheric pollutants, observed in the few available datasets, which could not easily be reconciled and combined into a unified, coherent and fully mechanistic theory. This explains to some extent the very different existing parameterisations. With the increasing, though still limited, availability of $\mathrm{N}_{\mathrm{r}}$ flux datasets, the knowledge and mechanistic understanding of surface -atmosphere exchanges grew over time, leading to increasing model complexity (big-leaf to multi-layer; dry deposition to bi-directional; fixed resistances to process-oriented). Still, much variation in dry deposition estimates may be expected between models, hinting that uncertainties remain rather large.

In 2006 the EU-sponsored NitroEurope Integrated Project (NEU for short) established a continent-wide network of 55 sites to monitor monthly ambient inorganic $\mathrm{N}_{\mathrm{r}}$ concentrations over a large range of ecosystems and to estimate dry deposition fluxes using inferential techniques (Sutton et al., 2007; Tang et al., 2009), with the final aim to interpret $\mathrm{CO}_{2}$ and greenhouse gas exchange across the network in relation to atmospheric $\mathrm{N}_{\mathrm{r}}$ inputs. The primary objective of this paper is to provide an ensemble average estimate of $\mathrm{N}_{\mathrm{r}}$ dry deposition for monitoring sites across the network, based on measured concentration data from the first two years of the project (2007-2008), and obtained by running four existing dry deposition schemes at the ecosystem scale.

A secondary objective of this study is to explore the differences in their output of modelled dry deposition and in their responses to input data, given the comprehensive dataset and wide range of vegetation types, meteorological conditions and pollution climates described by all monitoring sites. An alternative type of model intercomparison would focus on identifying the origin of the differences, i.e. the extent to which differences in model formulations and parameterisations contribute to the overall differences between dry deposition models (e.g. Schwede et al., 2011). Such an extensive analysis is beyond the scope of the present paper, however, as this study cannot accommodate all the comparisons of each resistance term and their formulations for four models and five major $\mathrm{N}_{\mathrm{r}}$ species. Instead, the four routines are broadly 
described and compared with a view to point out the major similarities and differences in the approaches adopted by each model. We focus on the end products of the models, i.e. deposition velocities and fluxes (Sect. 3.1), the differences in which can be viewed as measures of current uncertainties in dry deposition estimates from inferential networks. In addition, comparisons with long-term measured flux datasets (Sect. 3.3) also provide scope for identifying priority areas of potential improvements.

\section{Materials and methods}

\subsection{Dry deposition models}

The four dry deposition routines implemented in this study, which are currently used as modules within chemical transport models (CTMs) at national or continental scales in Europe and N. America, include the UK CBED scheme (Smith et al., 2000; Vieno, 2005), the Dutch IDEM model (Bleeker et al., 2004; Erisman et al., 1994; van Jaarsveld, 2004), the dry deposition module of the Environment Canada model (Zhang et al., 2001, 2003), termed "CDRY" here, and the surface exchange scheme of the EMEP model used under the CLRTAP (Simpson et al., 2003; see also Tuovinen et al., 2009, and refs therein). It should be noted that here we use the deposition module of EMEP version rv3.1 as documented in Simpson et al. (2003). The latest code (rv3.7, Simpson et al., 2010) carries a considerably different formulation for aerosol deposition, but is still undergoing testing. To distinguish these schemes we refer to the rv3.1 version as EMEP-03.

Note that the ecosystem/field-scale (inferential) application of dry deposition models, which is the topic here, should not be confused with regional (CTM) implementations of the same models. For the CTM versions of the models, in which the dry deposition schemes are embedded, the spatial patterns of dispersion, transport, chemistry and wet and dry deposition, as well as the whole regional mass balance of pollutants, are computed using input meteorological data from numerical weather prediction (NWP) models, prescribed emissions and land-use data. In the present application, however, the dry deposition routines are decoupled from any regional framework; they are driven instead at each individual site of the NEU network by local (field-scale) measurements of atmospheric concentrations, turbulence and meteorology. Thus, deposition estimates that are provided in this paper for any of the 4 models refer by default to "local" or ecosystemscale runs of the dry deposition routines, rather than to the grid square average $($ e.g. $50 \times 50 \mathrm{~km})$ that could be provided by the CTM version (unless otherwise specified). Consequently, this analysis only assesses the parameterisations of the dry deposition models, and not the ability of their respective CTM frameworks to predict meteorology, concentrations or the built-in representations of vegetation characteristics.

\subsubsection{Trace gases}

The surface-vegetation-atmosphere transfer (SVAT) models use broadly similar resistance frameworks for pollutant trace gas exchange. In its simplest form the dry deposition flux $F_{\chi}$ is given as the product of concentration at the reference height $\chi\left(z_{\text {ref }}\right)$ by the deposition velocity at the same level $V_{\mathrm{d}}\left(z_{\text {ref }}\right)$ :

$F_{\chi}=-\chi\left(z_{\text {ref }}\right) \times V_{\mathrm{d}}\left(z_{\text {ref }}\right)$

with, by convention, negative fluxes denoting deposition, and $V_{\mathrm{d}}$ the inverse sum of resistances in series:

$V_{\mathrm{d}}\left(z_{\mathrm{ref}}\right)=\left[R_{\mathrm{a}}\left(z_{\mathrm{ref}}, d+z_{0}\right)+R_{\mathrm{b}}+R_{\mathrm{c}}\right]^{-1}$

The atmospheric aerodynamic resistance, noted $R_{\mathrm{a}}\left(z_{\text {ref }}, d+\right.$ $\left.z_{0}\right)$ or $R_{\mathrm{a}}\left(z_{\text {ref }}\right)$ for short, characterises the efficiency of turbulent transfer from a reference height $z_{\text {ref }}$ in the surface layer down to $d+z_{0}, d$ being the displacement height and $z_{0}$ being the momentum roughness length; the quasi-laminar sublayer resistance $\left(R_{\mathrm{b}}\right)$ accounts for the transfer across a viscous, pseudo-laminar sub layer in the immediate vicinity of the vegetation or soil surface; and the surface or canopy resistance $\left(R_{\mathrm{c}}\right)$ characterises the surface affinity for pollutant uptake (Baldocchi et al., 1987; Monteith and Unsworth, 1990; Seinfeld and Pandis, 2006). Mathematical expressions for $R_{\mathrm{a}}$ and $R_{\mathrm{b}}$ are well documented; the method of calculation is very similar in the models, and the reader is referred to the literature for the various formulations. The main differences between dry deposition models reside in the parameterisations for $R_{\mathrm{c}}$. Differences in $R_{\mathrm{a}}$ and $R_{\mathrm{b}}$ do arise between models due to e.g. the use of marginally different atmospheric stability corrections, different assumptions regarding the viscous sublayer, and above all due to the model default value for $z_{0}$, which controls the magnitude of friction velocity $\left(u_{*}\right)$. The CBED model does not actually compute stability corrections for $R_{\mathrm{a}}$, based on the postulate that neutral conditions largely prevail over the windy British Isles (Smith et al., 2000). For the sake of model comparability, however, they are included here in the base runs of the CBED module and computed in an identical fashion to the EMEP03 scheme. Alternative runs of the CBED model, in which the stability corrections were not implemented, are compared with the base runs in Fig. A3 of the Supplement published online, showing that stability corrections have little impact on annually averaged modelled fluxes.

The canopy resistance for vegetated surfaces results from a network of sub-resistances within the canopy (Seinfeld and Pandis, 2006), with foliar stomatal $\left(R_{\mathrm{s}}\right)$, mesophyll $\left(R_{\mathrm{m}}\right)$, and non-stomatal $\left(R_{\mathrm{ns}}\right)$ or cuticular $\left(R_{\mathrm{cut}}\right)$ or water film $\left(R_{\mathrm{w}}\right)$ or external $\left(R_{\text {ext }}\right)$ resistances, as well as non foliage terms, e.g. the soil or ground surface resistance $\left(R_{\mathrm{gr}}\right)$. Most models (EMEP-03, IDEM, CDRY) also include an in-canopy aerodynamic resistance $\left(R_{\mathrm{ac}}\right)$, acting between the assumed big-leaf and ground surface, while the CBED approach is 
strictly single-layered. The main sub-resistances of $R_{\mathrm{c}}$ are briefly presented here; for details the reader is referred to the original publications. Note that all resistances are expressed in $\mathrm{s} \mathrm{m}^{-1}$ by default throughout this paper.

\section{Gaseous transfer through stomata}

Stomatal resistances to gaseous transfer are typically derived in the different models using a light-response function of the generic type (Jarvis, 1976):

$R_{\mathrm{s}}=R_{\mathrm{s}, \min }\left[1+\frac{b^{\prime}}{I_{\mathrm{p}}}\right] /\left(f_{\mathrm{e}} f_{\mathrm{w}} f_{T} f_{\mathrm{s}}\right)$

Here $I_{\mathrm{p}}$ is light intensity taken either as the photosynthetically active radiation (PAR) or global radiation $\left(S_{t}\right)$ as its proxy; $b^{\prime}$ is an empirical constant, $R_{\mathrm{s}, \min }$ is a minimum value of the stomatal resistance to water vapour, with $b^{\prime}$ and $R_{\mathrm{s} \text {, min }}$ taking characteristic values for each vegetation type or land use; the correction factors $f_{\mathrm{e}}, f_{\mathrm{w}}$ and $f_{T}$ account for the effects of increasing vapour pressure deficit (vpd), plant water stress and temperature, respectively (Jarvis, 1976). The $f_{\mathrm{w}}$ factor is set to 1 in all models except in CDRY, where it is actually parameterised as a function of global radiation. The $f_{\mathrm{e}}$ function is also set to 1 in CBED. The last factor $f_{\mathrm{s}}$ is a scaling factor to account for the difference in molecular diffusivity between water vapour and the trace gas considered. For the EMEP-03 model, the light response term is different and a further factor for phenology is also included (Emberson et al., 2001; Simpson et al., 2003).

Note that $R_{\mathrm{S}}$ in Eq. (3) is expressed on a unit leaf area (projected) basis, or equivalent to a unity leaf area index (LAI). All models except IDEM split PAR into its direct and diffuse fractions and compute the sunlit and shaded components of LAI, such that total (or bulk) stomatal resistance is calculated from sunlit and shaded resistances weighted by their respective LAI fractions (Baldocchi et al., 1987). Thus in CBED, CDRY and EMEP-03, the bulk stomatal conductance $G_{\mathrm{S}}$ (=inverse of bulk stomatal resistance) does not increase linearly with total LAI but tends to saturate for larger LAI levels. By contrast, IDEM uses by default a simplified version, in which LAI is not split into sunlit and shaded fractions, but where $G_{\mathrm{s}}$ is proportional to total LAI. The $R_{\mathrm{S}}$ routine by Wesely et al. (1989), which only requires global radiation and surface temperature as input, may be used as an option in IDEM when land use and vegetation characteristics are not well known.

\section{Non-stomatal resistances}

Although non-stomatal pathways, either on leaf cuticles or other non-foliar surfaces (stems, bark, ground, etc), provide an important, and often dominant, sink for atmospheric gases on an annual basis (Fowler et al., 2001, 2009; Flechard et al., 1998), there are as yet no consensual, generic and fully mechanistic parameterisations for non-stomatal resistances, which are variously termed $R_{\mathrm{ns}}, R_{\mathrm{ext}}, R_{\mathrm{w}}, R_{\text {cut }}, R_{\mathrm{gr}}$ in different models. This is partly due to the much greater technical and methodological difficulties, and larger uncertainties, involved in measuring trace $\mathrm{N}_{\mathrm{r}}$ gas (e.g. $\mathrm{NH}_{3}, \mathrm{HNO}_{3}$, $\mathrm{HONO}$, PAN) fluxes, let alone non-stomatal resistances, and also due to the resulting relative scarcity of reliable field observations, as compared with water vapour fluxes and $G_{\mathrm{s}}$. Also, in addition to the many environmental factors that have been shown or surmised to be involved in the control of non-stomatal resistances (e.g. wetness, temperature, vegetation type, pollution climate, soil $\mathrm{pH}$, leaf surface chemistry), it appears that hysteresis or "memory" effects control the rate of charge or discharge of the surface $\mathrm{N}_{\mathrm{r}}$ pool, espcially in the case of $\mathrm{NH}_{3}$ (Sutton et al., 1998; Flechard et al., 1999; Neirynck and Ceulemans, 2008; Burkhardt et al., 2009; Wichink Kruit et al., 2010), challenging the applicability of a (static) resistance approach.

For $\mathrm{NH}_{3}$, the four models use widely different empirical schemes for non-stomatal resistances, reflecting the spread in mean values and functional relationships found in the literature. This is consistent with the different ecosystems and pollution climates in which the original $\mathrm{NH}_{3}$ flux measurements were made (Nemitz et al., 2001; Massad et al., 2010). CBED actually uses a constant $R_{\mathrm{c}}$ of $20 \mathrm{~s} \mathrm{~m}^{-1}$ for forests and moorland, while for grasslands and crops the following $R_{\mathrm{W}}$ function is implemented (Smith et al., 2000):

$R_{\mathrm{W}} \mathrm{CBED}=10^{\log _{10}\left(T_{\mathrm{s}}+2\right)} \times \exp ^{\left(\frac{100-\mathrm{RH}}{7}\right)}$

with $T_{\mathrm{S}}$ surface temperature $\left({ }^{\circ} \mathrm{C}\right)$ and $\mathrm{RH}$ surface relative humidity (in \%). In frozen conditions $R_{\mathrm{W}}$ takes a constant value of either $1000 \mathrm{~s} \mathrm{~m}^{-1}\left(T_{\mathrm{S}}<-5^{\circ} \mathrm{C}\right)$ or $200 \mathrm{~s} \mathrm{~m}^{-1}$ $\left(-5^{\circ} \mathrm{C}<T_{\mathrm{S}}<0{ }^{\circ} \mathrm{C}\right)$. The EMEP-03 model uses the same basic formula EMEP-03's $F_{1}$ factor is the same as $R_{\mathrm{w}}$ (CBED), but then modulates $R_{\mathrm{w}}$ by a correction factor $F_{2}$ such that (Simpson et al., 2003):

$$
\begin{aligned}
& F_{2}=0.0455 \times 10^{\left(-1.1099 \times a_{\mathrm{SN}}+1.6769\right)} \\
& R_{\mathrm{ns}}(\mathrm{EMEP}-03)=\min \left[200, \max \left[2, R_{\mathrm{W}}(\mathrm{CBED}) \times F_{2}\right]\right]
\end{aligned}
$$

where $a_{\mathrm{SN}}$ is the ratio of atmospheric $\mathrm{SO}_{2}$ to $\mathrm{NH}_{3}$ mixing ratios. $F_{2}$ was quantified following the synthesis by Nemitz et al. (2001), who showed that $R_{\text {ext }}$ observations across 8 UK and Dutch sites declined exponentially with $a_{\mathrm{SN}}$, thus supporting the co-deposition hypothesis (Erisman and Wyers, 1993) that surface $\mathrm{NH}_{3}$ uptake was most efficient (i.e. $R_{\text {ext }}$ was smallest) at sites with a relative abundance of atmospheric $\mathrm{SO}_{2}$.

The $R_{\text {ext }}$ parameterisation for $\mathrm{NH}_{3}$ in IDEM also uses a functional dependence on RH (Eq. 7), although this is often supplanted by default values in given circumstances related to land use, season, snow cover, surface wetness, and surface acidity as quantified by the proxy $a_{\mathrm{SN}}$ (Erisman et al., 1994; 
Bleeker et al., 2004). Default $R_{\text {ext }}$ values range from typically $10-20 \mathrm{~s} \mathrm{~m}^{-1}$ in forests, moorland, crops and ungrazed pasture in wet conditions, to $200-1000 \mathrm{~s} \mathrm{~m}^{-1}$ in fertilised systems in dry summer night-time (Bleeker et al., 2004).

$R_{\text {ext }}($ IDEM $)=19257 \times \exp ^{(-0.094 \times \mathrm{RH})}+5$

In CDRY, explicit and specific parameterisations of $R_{\text {cut }}$ exist only for $\mathrm{SO}_{2}$ and $\mathrm{O}_{3}$ as functions of leaf wetness (dry vs. wet; dew vs. rain), relative humidity, leaf area index and friction velocity. Values of $R_{\text {cut }}$ for other gases are calculated as multipliers of $R_{\text {cut }}\left(\mathrm{SO}_{2}\right)$ or $R_{\text {cut }}\left(\mathrm{O}_{3}\right)$ or a combination of both. For $\mathrm{NH}_{3}, R_{\text {cut }}$ is taken to be identical to that for $\mathrm{SO}_{2}$, in both the wet (Eq. 8a) and dry (Eq. 8b) cases:

$$
\begin{aligned}
& R_{\text {cut }, \mathrm{w}}(\mathrm{CDRY})=\frac{R_{\mathrm{cut}, \mathrm{w} 0}}{u_{*} \times \mathrm{LAI}^{0.5}} \\
& R_{\text {cut }, \mathrm{d}}(\mathrm{CDRY})=\frac{R_{\mathrm{cut}, \mathrm{d} 0}}{\exp ^{0.03 \times \mathrm{RH}} u_{*} \times \mathrm{LAI}^{0.25}}
\end{aligned}
$$

with $R_{\text {cut,w0 }}$ and $R_{\text {cut }, \mathrm{d} 0}$ being land-use specific reference values (Zhang et al., 2003).

For $\mathrm{HNO}_{3}$, the scarcity of field flux measurements to date means that there are few data from which to derive parameterisations, and two models use near-zero $R_{\mathrm{c}}$ values in most cases (CBED, EMEP-03). By contrast IDEM implements a substantial $R_{\mathrm{c}}$ of $10 \mathrm{~s} \mathrm{~m}^{-1}$ by default and of $50 \mathrm{~s} \mathrm{~m}^{-1}$ for frozen or snow-covered surfaces, while CDRY models $R_{\text {cut }}$ $\left(\mathrm{HNO}_{3}\right)$ on the basis of the reference values for $\mathrm{SO}_{2}$ and $\mathrm{O}_{3}$ (Zhang et al., 2003), resulting in $R_{\mathrm{c}}$ values that are an order of magnitude smaller than those for $\mathrm{SO}_{2}$. For HONO, there are even less data available, and it is only treated by CDRY using an $R_{\mathrm{W}}$ value a factor 5 larger than that for $\mathrm{HNO}_{3}$.

Nitrogen dioxide exchange is assumed by all models to be exclusively downward (deposition only), and mostly (CDRY, EMEP-03, IDEM) or entirely (CBED) controlled by stomatal opening. In the EMEP-03 model, however, $\mathrm{NO}_{2}$ dry deposition is switched off whenever the ambient concentration falls below $4 \mathrm{ppb}$. This reflects the pseudo compensation point behaviour of $\mathrm{NO}_{2}$ exchange, due to $\mathrm{NO}$ emissions from the soil and conversion within plant canopies to $\mathrm{NO}_{2}$ through reaction with $\mathrm{O}_{3}$, that leads to net $\left(\mathrm{NO}_{\mathrm{x}}\right)$ emissions in the field at small ambient concentrations (Simpson et al., 2003).

\subsection{2 $\mathrm{NH}_{3}$ compensation point modelling}

One exception to the deposition-only $\left(R_{\mathrm{c}}\right)$ paradigm prevalent in surface/atmosphere $\mathrm{N}_{\mathrm{r}}$ exchange modelling is the bidirectional canopy compensation point approach for $\mathrm{NH}_{3}$ (Sutton et al., 1998), implemented in the CBED model for crops and grass land use classes (LUC) (Smith et al., 2000). Here, a non-zero canopy-equivalent potential, termed the canopy compensation point $\chi_{\mathrm{c}}$, determines the direction and sign of the flux when compared with the atmospheric concentration $\chi\left(z_{\text {ref }}\right)$, such that:

$F_{\chi}=-\frac{\chi\left(z_{\text {ref }}\right)-\chi_{\mathrm{c}}}{R_{\mathrm{a}}\left(z_{\mathrm{ref}}\right)+R_{\mathrm{b}}}$
The canopy compensation point is a function of, and quantifies the net bulk effect of, all source and sink terms within the canopy, but it is also a weak function of the atmospheric concentration $\chi\left(z_{\text {ref }}\right)$ itself (Nemitz et al., 2000a). In CBED, a basic version is implemented, where the stomatal compensation point $\left(\chi_{\mathrm{s}}\right)$ provides the only potential $\mathrm{NH}_{3}$ source, the dissolved $\mathrm{NH}_{3}$ and $\mathrm{NH}_{4}^{+}$pool in the apoplast of sub-stomatal cavities (Farquhar et al., 1980; Schjøerring et al., 1998; Massad et al., 2008) being mediated by the stomatal resistance $R_{\mathrm{S}}$, while $R_{\mathrm{W}}$ characterises the sink strength of non-stomatal foliar surfaces. Other mechanistic models (e.g. Nemitz et al., 2000a, b, 2001; Personne et al., 2009) consider additional $\mathrm{NH}_{3}$ sources in e.g. seed pods of oilseed rape and in the leaf litter and soil under winter wheat and grassland. Such approaches have not been implemented in CTMs to date, partly because this would require detailed (and generally unavailable) knowledge of sub-grid variations in $\mathrm{NH}_{3}$ concentrations, vegetation/crop type and fertilisation practices.

The stomatal compensation point in CBED is calculated following Eq. (11) assuming an apoplastic $\mathrm{pH}$ of 6.8 and intercellular $\mathrm{NH}_{4}^{+}$concentration of $600 \mu \mathrm{moll}^{-1}$, i.e. an apoplastic $\Gamma_{\mathrm{s}}$ ratio $\left(=\left[\mathrm{NH}_{4}^{+}\right] /\left[\mathrm{H}^{+}\right]\right)$of 3785 :

$\chi_{\mathrm{s}}=\frac{K_{\mathrm{a}}\left(T_{\mathrm{s}}\right)}{K_{\mathrm{h}}\left(T_{\mathrm{s}}\right)} \Gamma_{\mathrm{s}}$

with $K_{\mathrm{a}}\left(T_{\mathrm{s}}\right)$ the dissociation constant of $\mathrm{NH}_{3}$ in water (Bates and Pinching, 1950) and $K_{\mathrm{h}}\left(T_{\mathrm{S}}\right)$ the Henry coefficient for $\mathrm{NH}_{3}$ (Dasgupta and Dong, 1986). The canopy compensation point itself is given as (Sutton et al., 1998):

$$
\chi_{\mathrm{c}}=\frac{\frac{\chi\left(z_{\text {ref }}\right)}{\left[R_{\mathrm{a}}\left(z_{\mathrm{ref}}\right)+R_{\mathrm{b}}\right]}+\frac{\chi_{\mathrm{s}}}{R_{\mathrm{s}}}}{\left[R_{\mathrm{a}}\left(z_{\mathrm{ref}}\right)+R_{\mathrm{b}}\right]^{-1}+R_{\mathrm{S}}^{-1}+R_{\mathrm{w}}^{-1}}
$$

The canopy compensation point approach described here is applicable to crops and grasslands only outside periods of mineral or organic fertilisation, during which $\mathrm{NH}_{3}$ emission is governed by very different mechanisms (see Sect. 2.3.3).

\subsubsection{Aerosol deposition}

Aerosol dry deposition fluxes are computed as the product of air particle concentration by deposition velocity (Eq. 1). Parameterisations for aerosol $V_{\mathrm{d}}$ range from the strongly mechanistic to the fully empirical, depending on the model and the ion species considered. The 2003 version of the unified EMEP model (EMEP-03), the CDRY scheme and to some extent the IDEM model, are originally based on Slinn's approach (Slinn, 1982), but have distinctly different features. In EMEP-03, $V_{\mathrm{d}}$ is calculated as (Simpson et al., 2003):

$$
V_{\mathrm{d}}\left(z_{\text {ref }}\right)=\frac{1}{R_{\mathrm{a}}\left(z_{\text {ref }}\right)+R_{\mathrm{b}}+\left[R_{\mathrm{a}}\left(z_{\text {ref }}\right) \times R_{\mathrm{b}} \times V_{\mathrm{g}}\right]}+V_{\mathrm{g}}
$$

where $V_{\mathrm{g}}$ is the gravitational settling (or sedimentation) velocity (Seinfeld and Pandis, 2006), calculated as a function of 
particle diameter $\left(D_{\mathrm{p}}\right)$, and $R_{\mathrm{b}}$ is calculated from explicit formulations from the literature that are particle size- and vegetation/land use-dependent.

By contrast, CDRY does not explicitly compute $R_{\mathrm{b}}$ but uses an overall surface resistance $\left(R_{\text {surf }}\right)$ concept such that (Zhang et al., 2001):

$V_{\mathrm{d}}\left(z_{\text {ref }}\right)=\frac{1}{R_{\mathrm{a}}\left(z_{\text {ref }}\right)+R_{\text {surf }}}+V_{\mathrm{g}}$

$R_{\mathrm{surf}}=\frac{1}{\varepsilon_{0} u_{*} R_{1}\left(E_{\mathrm{B}}+E_{\mathrm{IN}}+E_{\mathrm{IM}}\right)}$

where $\varepsilon_{0}$ is an empirical constant and $R_{1}$ the fraction of particles that stick to the surface. Parameters used to calculate aerosol collection efficiencies $E_{\mathrm{B}}$ (Brownian diffusion), $E_{\mathrm{IN}}$ (interception) and $E_{\mathrm{IM}}$ (impaction) are land-use and seasondependent.

In IDEM, the deposition velocity for particulate $\mathrm{NH}_{4}^{+}$and $\mathrm{NO}_{3}^{-}$is calculated according to Wesely et al. (1985) for short vegetation and other areas with a momentum roughness length smaller than $0.5 \mathrm{~m}$. For forests and other areas with $z_{0}>0.5 \mathrm{~m}$, the scheme by Ruijgrok et al. (1997) is used, such that:

$V_{\mathrm{d}}\left(z_{\mathrm{ref}}\right)=\frac{1}{R_{\mathrm{a}}\left(z_{\mathrm{ref}}\right)+V_{\mathrm{ds}}^{-1}}+V_{\mathrm{g}}$

$V_{\mathrm{ds}}=E \frac{u_{*}^{2}}{U_{h \mathrm{c}}}$

with $V_{\mathrm{ds}}$ the surface deposition velocity, $E$ the overall collection efficiency and $U_{h}$ the wind speed at canopy height $\left(h_{\mathrm{c}}\right)$. It can readily be seen that $V_{\mathrm{ds}}$ is equivalent to $R_{\text {surf }}^{-1}$ of CDRY (Eq. 13), but Ruigrok et al. (1997) derived simplified relationships for the overall collection efficiency $E$ and $V_{\mathrm{ds}}$ for the chemical species $\mathrm{NH}_{4}^{+}, \mathrm{SO}_{4}^{2-}, \mathrm{NO}_{3}^{-}$and $\mathrm{Na}^{+}$and other base cations under various conditions. For $\mathrm{RH}<80 \% \mathrm{E}$ is of the form:

$E=\alpha u_{*}^{\beta}$

where the empirical constants $\alpha$ and $\beta$ are chemical speciesand surface wetness-dependent. For relative humidity above $80 \%$ they introduce a dependence on relative humidity to account for the observed increased $V_{\mathrm{ds}}$ with growing particle diameter $\left(D_{\mathrm{p}}\right)$. In IDEM, the calculation scheme for the settling velocity $V_{\mathrm{g}}$ (implemented for large particles only) is similarly simplified. Note that gravitational settling is included conceptually in Eqs. (13), (14) and (16), although it is negligible for the fine aerosol fraction (aerodynamic diameter $<1 \mu \mathrm{m}$ ), where most of $\mathrm{NH}_{4}^{+}$and $\mathrm{NO}_{3}^{-}$mass is likely found, and only becomes relevant for coarse particles.

The CBED model currently calculates $\mathrm{NH}_{4}^{+}, \mathrm{NO}_{3}^{-}$ and $\mathrm{SO}_{4}^{2-}$ aerosol deposition velocities using a simple, empirically-derived scheme, whereby $V_{\mathrm{d}}$ is the product of $u_{*}$ times a tabulated land use- and chemical species-specific constant $(\alpha)$. The parameter $\alpha$ is of the order of 0.005 for grassland and semi-natural vegetation, of 0.01 for arable land, and of 0.02-0.03 for forests (for $u_{*}$ and $V_{\mathrm{d}}$ expressed in the same unit e.g. $\left.\mathrm{m} \mathrm{s}^{-1}\right)$; also, $\alpha\left(\mathrm{NO}_{3}^{-}\right)$is $49 \%, 36 \%$ and $60 \%$ larger than $\alpha\left(\mathrm{NH}_{4}^{+}\right)$for grassland/semi-natural, arable land and forests, respectively (R. I. Smith and E. Nemitz, CEH Edinburgh, unpublished data). These $\alpha$ values were derived by weighting measured curves of $V_{\mathrm{d}}\left(D_{\mathrm{p}}\right) / u_{*}$ over different ecosystems (Gallagher et al., 1997; Nemitz et al., 2002; Joutsenoja, 1992) with typical size-distributions of nitrate and ammonium.

\subsection{NitroEurope inferential network sites}

Reactive nitrogen dry deposition was estimated by field-scale inferential modelling at the 55 monitoring sites of the NitroEurope network (Sutton et al., 2007; Tang et al., 2009) where all necessary input data, including $\mathrm{N}_{\mathrm{r}}$ atmospheric concentrations, meteorological and/or micrometeorological data, were available for the two years 2007-2008, or at least one full year. The network included 29 forest (F) stations; 9 semi-natural short vegetation ecosystems (SN) e.g. semi-arid steppe, alpine or upland grasslands, moorlands and fens; 8 fertilised, productive grasslands (G); and 9 cropland (C) sites (Table 1). All NEU inferential sites, with the exception of DE-Hoe, FI-Lom, NL-Spe and UA-Pet, were also $\mathrm{CO}_{2}$ flux monitoring stations of the EU-funded CarboEurope Integrated Project (http://www.carboeurope.org/), which aimed at an assessment of the European terrestrial carbon balance (Dolman et al., 2008). Sites locations and vegetation characteristics are summarised in Table 1, as well as in Fig. A1 of the online Supplement; details and photographs may be obtained from the CarboEurope-IP database (http: //gaia.agraria.unitus.it/database/carboeuropeip/), or from the list of selected references provided in Table A1 of the Supplement. The study sites were distributed across Europe from Ireland to Russia and from Finland to Portugal, with mean annual temperatures ranging from $-0.1^{\circ} \mathrm{C}$ (FI-Lom) to $17.8^{\circ} \mathrm{C}$ (ES-ES1), and mean annual rainfall ranging from $464 \mathrm{~mm}$ (UA-Pet) to $1450 \mathrm{~mm}$ (IE-Dri). Sites elevations range from $-2 \mathrm{~m}$ a.m.s.l. (NL-Hor) to $1765 \mathrm{~m}$ a.m.s.l. (ESVDA). Measured maximum canopy heights $\left(h_{\mathrm{c}}\right)$ and LAI are on average $20.2 \mathrm{~m} / 4.9 \mathrm{~m}^{2} \mathrm{~m}^{-2}$ for forests, $0.8 \mathrm{~m} / 3.2 \mathrm{~m}^{2} \mathrm{~m}^{-2}$ for semi-natural vegetation, $0.4 \mathrm{~m} / 5.5 \mathrm{~m}^{2} \mathrm{~m}^{-2}$ for grasslands and $1.8 \mathrm{~m} / 7.0 \mathrm{~m}^{2} \mathrm{~m}^{-2}$ for crops.

\subsection{Input data and model implementation}

\subsubsection{Ecosystem and micrometeorological data}

For a detailed description of the management of input data and model implementation at the ecosystem scale for all NEU monitoring sites, the reader is referred to the online Supplement. Briefly, the model base runs used measured values of $h_{\mathrm{c}}$ as inputs, whereas for LAI inputs the model default 
Table 1. NitroEurope inferential network monitoring sites ${ }^{1}$.

\begin{tabular}{|c|c|c|c|c|c|c|c|c|c|c|}
\hline $\begin{array}{l}\text { Site } \\
\text { Code }\end{array}$ & $\begin{array}{l}\text { Site } \\
\text { Name }\end{array}$ & $\begin{array}{l}\text { Land use/ } \\
\text { Dominant vegetation }\end{array}$ & $\mathrm{LU}^{2}$ & $\begin{array}{l}\text { Lat. } \\
{ }^{\circ} \mathrm{N}\end{array}$ & $\begin{array}{l}\text { Long. } \\
{ }^{\circ} \mathrm{E}\end{array}$ & $\begin{array}{r}\text { Altitude } \\
\text { m a.m.s.l. }\end{array}$ & $\begin{array}{r}\text { Temp. } \\
{ }^{\circ} \mathrm{C}\end{array}$ & $\begin{array}{r}\text { Rainfall } \\
\mathrm{mm}\end{array}$ & $\begin{array}{r}h_{\mathrm{c}}^{3} \\
\mathrm{~m}\end{array}$ & $\begin{array}{r}\mathrm{LAI}^{4} \\
\mathrm{~m}^{2} \mathrm{~m}^{-2}\end{array}$ \\
\hline BE-Bra & Brasschaat & Scots pine, pedunculate oak & $\mathrm{F}$ & 51.31 & 4.52 & 16 & 11.2 & 770 & 22 & 2 \\
\hline BE-Vie & Vielsalm & Eur. beech, coast douglas fir & $\mathrm{F}$ & 50.31 & 6.00 & 450 & 8.4 & 1000 & 30 & 5 \\
\hline CH-Lae & Laegeren & Ash, sycamore, beech, spruce & $\mathrm{F}$ & 47.48 & 8.37 & 689 & 7.6 & 1100 & 30 & 6 \\
\hline CZ-BK1 & Bily Kriz & Norway spruce & $\mathrm{F}$ & 49.50 & 18.54 & 908 & 8.3 & 1200 & 13 & 9 \\
\hline DE-Hai & Hainich & Eur. beech, maple, ash & $\mathrm{F}$ & 51.08 & 10.45 & 430 & 8.7 & 775 & 33 & 7 \\
\hline DE-Hoe & Höglwald & Norway spruce & $\mathrm{F}$ & 48.30 & 11.10 & 540 & 7.8 & 870 & 35 & 6 \\
\hline DE-Tha & Tharandt & Norway spruce, scots pine & $\mathrm{F}$ & 50.96 & 13.57 & 380 & 9.2 & 820 & 27 & 8 \\
\hline DE-Wet & Wetzstein & Norway spruce & $\mathrm{F}$ & 50.45 & 11.46 & 785 & 6.7 & 950 & 22 & 8 \\
\hline DK-Sor & Soroe & Eur. beech & $\mathrm{F}$ & 55.49 & 11.65 & 40 & 9.0 & 730 & 31 & 5 \\
\hline ES-ES1 & El Saler & Aleppo pine, stone pine, macchia & $\mathrm{F}$ & 39.35 & -0.32 & 5 & 17.8 & 551 & 10 & 3 \\
\hline ES-LMa & Las Majadas & Open holm oak, shrubs & $\mathrm{F}$ & 39.94 & -5.77 & 258 & 15.8 & 528 & 8 & 1 \\
\hline FI-Hyy & Hyytiälä & Scots pine & $\mathrm{F}$ & 61.85 & 24.30 & 181 & 4.8 & 709 & 14 & 7 \\
\hline FI-Sod & Sodankylä & Scots pine & $\mathrm{F}$ & 67.36 & 26.64 & 180 & 0.7 & 499 & 13 & 1 \\
\hline FR-Fon & Fontainbleau & Oak & $\mathrm{F}$ & 48.48 & 2.78 & 92 & 11.3 & 690 & 28 & 5 \\
\hline FR-Hes & Hesse & Eur. beech & $\mathrm{F}$ & 48.67 & 7.07 & 300 & 10.3 & 975 & 16 & 5 \\
\hline FR-LBr & Le Bray & Maritime pine & $\mathrm{F}$ & 44.72 & -0.77 & 61 & 12.9 & 972 & 22 & 3 \\
\hline FR-Pue & Puechabon & Holm oak & $\mathrm{F}$ & 43.74 & 3.60 & 270 & 13.7 & 872 & 6 & 3 \\
\hline IT-Col & Collelongo & Eur. beech & $\mathrm{F}$ & 41.85 & 13.59 & 1560 & 7.5 & 1140 & 22 & 7 \\
\hline IT-Ren & Renon & Norway spruce, stone pine & $\mathrm{F}$ & 46.59 & 11.43 & 1730 & 4.9 & 1010 & 29 & 5 \\
\hline IT-Ro2 & Roccarespampani & Turkey oak, downy oak & $\mathrm{F}$ & 42.39 & 11.92 & 224 & 15.1 & 876 & 17 & 4 \\
\hline IT-SRo & San Rossore & Maritime pine, holm oak & $\mathrm{F}$ & 43.73 & 10.28 & 4 & 15.2 & 920 & 18 & 4 \\
\hline NL-Loo & Loobos & Scots Pine & $\mathrm{F}$ & 52.17 & 5.74 & 25 & 10.4 & 786 & 17 & 2 \\
\hline NL-Spe & Speulderbos & Douglas fir, Jap. larch, Eur. Beech & $\mathrm{F}$ & 52.25 & 5.69 & 52 & 9.7 & 966 & 32 & 11 \\
\hline PT-Esp & Espirra & Eucalyptus coppice & $\mathrm{F}$ & 38.64 & -8.60 & 95 & 16.2 & 709 & 20 & 5 \\
\hline PT-Mi1 & Mitra II (Evora) & Cork oak & $\mathrm{F}$ & 38.54 & -8.00 & 264 & 15.4 & 665 & 7 & 3 \\
\hline RU-Fyo & Fyodorovskoye & Norway spruce & $\mathrm{F}$ & 56.46 & 32.92 & 265 & 5.3 & 711 & 21 & 3 \\
\hline SE-Nor & Norunda & Norway spruce, scots pine & $\mathrm{F}$ & 60.08 & 17.47 & 45 & 7.0 & 527 & 25 & 5 \\
\hline SE-Sk2 & Skyttorp & Scots pine, Norway spruce & $\mathrm{F}$ & 60.13 & 17.84 & 55 & 5.5 & 527 & 14 & 3 \\
\hline UK-Gri & Griffin & Sitka Spruce & $\mathrm{F}$ & 56.62 & -3.80 & 340 & 7.8 & 1200 & 9 & 8 \\
\hline DE-Meh & Mehrstedt & Afforestated grassland & $\mathrm{SN}$ & 51.28 & 10.66 & 293 & 8.5 & 547 & 0.5 & 2.9 \\
\hline ES-VDA & Vall d'Alinyà & Upland grassland & $\mathrm{SN}$ & 42.15 & 1.45 & 1765 & 7.1 & 1064 & 0.1 & 1.4 \\
\hline FI-Lom & Lompolojänkkä & Sedge fen & $\mathrm{SN}$ & 68.21 & 24.35 & 269 & -0.1 & 500 & 0.4 & 1.0 \\
\hline HU-Bug & Bugac & Semi-arid grassland & $\mathrm{SN}$ & 46.69 & 19.60 & 111 & 10.8 & 500 & 0.5 & 4.7 \\
\hline T-Amp & Amplero & Grassland & $\mathrm{SN}$ & 41.90 & 13.61 & 884 & 9.6 & 1365 & 0.4 & 2.5 \\
\hline IT-MBo & Monte Bondone & Upland grassland & $\mathrm{SN}$ & 46.03 & 11.08 & 1550 & 5.5 & 1189 & 0.3 & 2.5 \\
\hline NL-Hor & Horstermeer & Natural fen (peat) & SN & 52.03 & 5.07 & -2 & 10.8 & 800 & 2.5 & 6.9 \\
\hline PL-wet & POLWET & Wetland (reeds, carex, sphagnum) & $\mathrm{SN}$ & 52.76 & 16.31 & 54 & 8.9 & 550 & 2.1 & 4.9 \\
\hline UK-AMo & Auchencorth Moss & Blanket bog & $\mathrm{SN}$ & 55.79 & -3.24 & 270 & 7.6 & 798 & 0.6 & 2.1 \\
\hline CH-Oe1 & Oensingen & Cut Grassland & G & 47.29 & 7.73 & 450 & 9.4 & 1200 & 0.6 & 6.6 \\
\hline DE-Gri & Grillenburg & Cut Grassland & G & 50.95 & 13.51 & 375 & 9.0 & 861 & 0.7 & 6.0 \\
\hline DK-Lva & Rimi & Cut Grassland & $\mathrm{G}$ & 55.70 & 12.12 & 8 & 9.2 & 600 & 0.5 & 3.5 \\
\hline FR-Lq2 & Laqueuille & Grazed Grassland & G & 45.64 & 2.74 & 1040 & 7.5 & 1100 & 0.2 & 2.4 \\
\hline IE-Ca2 & Carlow & Grazed Grassland & G & 52.85 & -6.90 & 56 & 9.4 & 804 & 0.2 & 5.7 \\
\hline IE-Dri & Dripsey & Grazed Grassland & $\mathrm{G}$ & 51.99 & -8.75 & 187 & 9.6 & 1450 & 0.5 & 4.0 \\
\hline NL-Ca1 & Cabauw & Grazed Grassland & G & 51.97 & 4.93 & -1 & 11.1 & 786 & 0.2 & 9.9 \\
\hline $\mathrm{UK}-\mathrm{EBu}$ & Easter Bush & Grazed Grassland & G & 55.87 & -3.21 & 190 & 9.0 & 870 & 0.2 & 5.5 \\
\hline BE-Lon & Lonzee & Crop rotation & $\mathrm{C}$ & 50.55 & 4.74 & 165 & 9.1 & 772 & 0.9 & 6 \\
\hline DE-Geb & Gebesee & Crop rotation & $\mathrm{C}$ & 51.10 & 10.91 & 162 & 10.1 & 492 & 1.0 & 5.5 \\
\hline DE-Kli & Klingenberg & Crop rotation & $\mathrm{C}$ & 50.89 & 13.52 & 478 & 8.1 & 850 & 2.2 & 5.0 \\
\hline DK-Ris & Risbyholm & Crop rotation & $\mathrm{C}$ & 55.53 & 12.10 & 10 & 9.0 & 575 & 1.0 & 4.6 \\
\hline FR-Gri & Grignon & Crop rotation & $\mathrm{C}$ & 48.84 & 1.95 & 125 & 11.1 & 600 & 2.4 & 6.2 \\
\hline IT-BCi & Borgo Cioffi & Crop rotation & $\mathrm{C}$ & 40.52 & 14.96 & 20 & 16.4 & 490 & 3.0 & 7.3 \\
\hline IT-Cas & Castellaro & Maize/Rice rotation & $\mathrm{C}$ & 45.06 & 8.67 & 89 & 13.2 & 984 & 2.8 & 4.9 \\
\hline UA-Pet & Petrodolinskoye & Crop Rotation & $\mathrm{C}$ & 46.50 & 30.30 & 66 & 10.1 & 464 & 0.6 & 4.2 \\
\hline UK-ESa & East Saltoun & Crop rotation & $\mathrm{C}$ & 55.90 & -2.84 & 97 & 8.5 & 700 & $\mathrm{na}^{5}$ & na \\
\hline
\end{tabular}

${ }^{1}$ See Table A1 in the online Supplement for literature references for each site.

${ }^{2}$ Land use/ecosystem type: F: forest; SN: semi-natural short vegetation; G: grassland (G); C: cropland.

${ }^{3}$ Canopy height: mean tree height for F; annual maximum value for SN, G and C.

${ }^{4}$ Leaf area index: annual maximum; the measurement type (single-sided, projected, total) is not specified.

5 "na": not available. 
values were used preferentially, due to the uncertainties in measured estimates of LAI. A comparison of model default values of LAI and $h_{\mathrm{c}}$ with actual measurements is shown in Fig. $1 \mathrm{c}$ and d.

For $u_{*}$ and sensible heat flux $(H)$, actual measurements from EC datasets at each site were used whenever possible, and data were otherwise gap-filled from standard meteorological data (cf. Sect. A3 in Supplement). Measurements of canopy wetness were available at very few sites, and thus a dynamic surface wetness energy balance model was coupled to the modelling framework for most sites; a comparison with actual measurements is shown in Sect. A5 of Supplement.

Alternative model runs were computed to investigate the sensitivity of annual fluxes to input values of $h_{\mathrm{c}}$ and LAI and to surface temperature and relative humidity, as detailed in Sects. A2 and A4 of the Supplement, with the characteristics of the base and sensitivity runs being summarised in Table A2 therein.

\subsubsection{Atmospheric $\mathrm{N}_{\mathrm{r}}$ concentration data}

\section{Pollutant monitoring by denuder and filter sampling}

Ambient $\mathrm{N}_{\mathrm{r}}$ concentrations of gaseous $\mathrm{NH}_{3}, \mathrm{HNO}_{3}$ and $\mathrm{HONO}$ and aerosol $\mathrm{NH}_{4}^{+}$and $\mathrm{NO}_{3}^{-}$were monitored monthly at the 55 sites of the inferential network from early 2007 onwards using DELTA systems (DEnuder for Long-Term Atmospheric sampling, described in detail in Sutton et al., 2001 and Tang et al., 2009) (Table 2). Briefly, the DELTA sampling "train" consists of two coated borosilicate glass denuder tubes in series for scrubbing acidic trace gases $\left(\mathrm{HNO}_{3}\right.$, $\mathrm{SO}_{2}, \mathrm{HCl}, \mathrm{HONO}$ ), followed by two denuders for $\mathrm{NH}_{3}$ and finally by a filter-pack assembly with a first impregnated filter to capture aerosol phase anions $\left(\mathrm{NO}_{3}^{-}, \mathrm{SO}_{4}^{2-}, \mathrm{Cl}^{-}\right)$as well as base cations $\left(\mathrm{Na}^{+}, \mathrm{Mg}^{2+}, \mathrm{Ca}^{2+}\right)$, and a second filter to collect the evolved particulate $\mathrm{NH}_{4}^{+}$. Air is sampled at a rate of $0.3-0.41 \mathrm{~min}^{-1}$ and directly into the first denuder with no inlet line to avoid sampling losses. Denuders for acid gases and filters for aerosol anions and base cations are coated/impregnated with potassium carbonate/glycerol, while for gaseous $\mathrm{NH}_{3}$ and aerosol $\mathrm{NH}_{4}^{+}$citric acid or phosphorous acid is used. The empirically determined effective size cut-off for aerosol sampling is of the order of $4.5 \mu \mathrm{m}$ (E. Nemitz, unpublished data).

The DELTA sampling trains were prepared and assembled in seven coordinator laboratories (CEAM, Spain; CEH, United Kingdom; FAL/vTI, Germany; INRA, France; MHSC, Croatia; NILU, Norway; and SHMU, Slovakia), sent out to the inferential sites for monthly field exposure, then sent back to the laboratories for denuder/filter extraction and analysis. The DELTA systems thus provided monthly mean ambient $\mathrm{N}_{\mathrm{r}}$ concentrations for each site of the network; this paper deals, unless otherwise stated, with the data col- lected during the first two years (2007-2008) of the whole monitoring period (2007-2010).

To ensure comparability of data provided by the different laboratories, DELTA intercomparison campaigns were carried out at yearly intervals at selected sites as part of a defined QA/QC programme, whereby seven sample trains (one provided by each laboratory) were exposed side by side for a month and then extracted and analysed by each laboratory (Tang et al., 2009). In addition to this full intercomparison exercise, in which the whole sample train management (preparation, coating, impregnation, assembly, dispatching, exposure, field handling, extraction, analysis) was tested, each laboratory also regularly received synthetic solutions for "blind" analysis from three chemical intercomparison centres: CEH, Scotland; EMEP/NILU, Norway; and the Global Atmospheric Watch program (GAW) of the WMO. The results of the first DELTA intercomparisons were presented in Tang et al. (2009); an in-depth analysis of the full concentration dataset will be published in a companion paper (Tang et al., 2011).

In addition to the monthly denuder and filter $\mathrm{N}_{\mathrm{r}}$ concentration data provided by DELTA systems, ambient $\mathrm{NO}_{2}$ concentrations were monitored by chemiluminescence on an hourly or half-hourly basis at a number of sites (BE-Bra, FI-Hyy, ITRen, NL-Spe, FI-Lom, HU-Bug, UK-AMo, CH-Oe1, UK$\mathrm{EBu}$, FR-Gri, IT-Cas). Although $\mathrm{NO}_{2}$ concentrations were not measured at all sites, and although $\mathrm{NO}_{2}$ measurements based on a conversion to NO by molybdenum converters, followed by $\mathrm{O}_{3}$ chemiluminescence, are known to be biased high due to interferences by PAN and $\mathrm{HNO}_{3}$ (Steinbacher et al., 2007), the available data are useful to assess the likely magnitude of ecosystem $\mathrm{NO}_{2}$ uptake relative to total $\mathrm{N}_{\mathrm{r}}$ dry deposition and the variability between model predictions for $\mathrm{NO}_{2}$ deposition. For the remaining sites, mean modelled $\mathrm{NO}_{2}$ concentrations from the EMEP $50 \mathrm{~km} \times 50 \mathrm{~km}$ model output for the year 2004 were used.

\section{Aerosol size distribution}

The extraction of DELTA filters yielded total aerosol concentrations, as the fractions of fine vs. coarse aerosols could not be determined for each of $\mathrm{NH}_{4}^{+}, \mathrm{NO}_{3}^{-}$or other chemical species. For the two aerosol $V_{\mathrm{d}}$ schemes (CBED, IDEM) that do not explicitly model aerosol size-dependent deposition velocities, but instead calculate a species-specific mean $V_{\mathrm{d}}$ across the aerosol size range, this was not an issue. However, in both the EMEP-03 and CDRY models, aerosol $V_{\mathrm{d}}$ is a function of particle diameter $D_{\mathrm{p}}$. In EMEP-03 two deposition velocities are calculated, one for each of fine $\left(D_{\mathrm{p}}=\right.$ $0.3 \mu \mathrm{m})$ and coarse $\left(D_{\mathrm{p}}=4 \mu \mathrm{m}\right)$ aerosols, independent of the chemical species considered. In CDRY, species-specific values of the geometric mean mass diameter (DG) and geometric standard deviation (GSD) are attributed to both fine and coarse aerosol modes, and two log-normal particle size 
distributions are generated on the basis of DG and GSD, one for each mode. In both models, therefore, the fine and coarse fractions of the total aerosol loading measured on the DELTA filters need to be estimated, so that modelled $V_{\mathrm{d}}$ is applied to the concentration in the appropriate size range. In the CTM versions of EMEP-03 and CDRY, fine and coarse fractions are calculated dynamically within the regional chemical model, but in the present local-scale application such data are not available. By default, and in a first approximation, fine aerosol was assumed to account for $94 \%$ of total $\mathrm{NH}_{4}^{+}$and $81 \%$ of total $\mathrm{NO}_{3}^{-}$, following Ruijgrok et al. (1997), realising that in reality this ratio will be site specific, especially for $\mathrm{NO}_{3}^{-}$(Zhang et al., 2008; Torseth et al., 2000), which has a larger contribution from coarse $\mathrm{NaNO}_{3}$ at coastal sites.

\section{Corrections for within-canopy concentration data}

At most sites of the NEU network, air sampling by DELTA systems provided concentrations at least $1 \mathrm{~m}$ above the canopy. However, at 10 forest sites (BE-Vie, DE-Hai, DETha, ES-ES1, ES-LMa, FI-Sod, IT-Ren, PT-Mi1, SE-Nor, SE-Sk2), the DELTA system was actually set up in a clearing or in the trunk space, typically 1.5 to 2 mabove the forest floor. This was for practical reasons, mostly to facilitate the safe exchange of sampling trains in challenging winter conditions or windy weather. The inferential method requires atmospheric concentrations and turbulence intensity above the canopy to predict rates of dry deposition to the forest, and thus the validity of clearing or below-crown concentrations as proxies of above-canopy concentrations can be questioned and needs to be examined (Zhang et al., 2009; Tuovinen et al., 2009). There are very few published within-canopy (vertical) $\mathrm{NH}_{3}$ and $\mathrm{HNO}_{3}$ concentration profiles in the literature for forests. Within-canopy profile data for $\mathrm{NH}_{3}$ have been obtained mostly in grasslands (Nemitz et al., 2009) and crops such as oilseed rape (Nemitz et al., 2000b) and maize (Bash et al., 2010). These data showed consistently larger concentrations near the ground and below canopy, compared with above the canopy, indicative of $\mathrm{NH}_{3}$ sources in the ground and in the leaf litter as well as within the canopy itself, especially following fertilisation. In forests, however, soil and leaf litter are less likely to be strong $\mathrm{NH}_{3}$ emitters due to a generally smaller $\mathrm{pH}$ and/or $\mathrm{N}$ limitations compared with fertilised systems, and we assume in this study that deposition to the forest floor prevails. We consequently surmise that $\mathrm{NH}_{3}$ concentrations measured in clearings and below canopy are consistently smaller than above treetops, in a similar fashion to the $\mathrm{SO}_{2}$ and $\mathrm{HNO}_{3}$ data obtained at the Oak Ridge site of the U.S. AIRMoN inferential network (Hicks, 2006). There, the tower/clearing concentration ratio was on average 1.26 for $\mathrm{SO}_{2}, 1.34$ for $\mathrm{HNO}_{3}$ and 1.07 for particulate $\mathrm{SO}_{4}^{2-}$. There were seasonal variations in the tower/clearing ratio, especially for $\mathrm{SO}_{2}$ and $\mathrm{HNO}_{3}$, with generally larger values (up to $1.4-1.5)$ in the second half of the year and annual lows
(1.1-1.2) in late winter, which were attributed to changes in LAI of the mixed forest, although it was concluded that not enough data were available as yet to derive robust corrections based on LAI. In a first approximation we thus applied a constant correction factor of 1.3 to $\mathrm{NH}_{3}$ and $\mathrm{HNO}_{3}$ concentrations measured in clearings or below trees at the aforementioned sites; for particulate $\mathrm{NH}_{4}^{+}$and $\mathrm{NO}_{3}^{-}$we used a correction factor identical to the mean $\mathrm{SO}_{4}^{2-}$ tower/clearing ratio of 1.07 reported by Hicks (2006).

\subsubsection{Modelling and integrating annual fluxes}

The inferential models were run on a half-hourly time step, which was the frequency of input micrometeorological data in the CarboEurope IP database. The atmospheric and surface resistance terms, the $\mathrm{NH}_{3}$ compensation points (where applicable), and the aerosol deposition velocities, were computed whenever all necessary input data were available for the 2-year period 2007-2008. Half-hourly fluxes were calculated from half-hourly exchange parameters $\left(V_{\mathrm{d}}, \chi_{\mathrm{c}}\right)$ and monthly gas/aerosol DELTA concentrations, or hourly data in the case of measured $\mathrm{NO}_{2}$. Note that for the monthly DELTA data, none of the diurnal or day-to-day variations in concentrations were known, except at very few sites where intensive, high resolution measurements were made; potential correlations on daily time scales between concentration and $V_{\mathrm{d}}$ could lead to significant systematic bias in the modelled fluxes at some sites (Matt and Meyers, 1993), but this was not investigated here.

For cases when all input data were available throughout the 2-year measurement period, the monthly and annual fluxes can simply be obtained by adding up all modelled half-hourly fluxes. In practise, however, there were at most sites periods of a few hours to a few days or weeks during which at least one key variable (such as windspeed, temperature or relative humidity) was missing, e.g. due to instrument malfunction, breakdown, power cuts or theft/vandalism, such that mechanistic gap-filling for fluxes was precluded. A simple upscaling procedure based on the arithmetic mean of all modelled fluxes multiplied by the total number of 30-minute time intervals in the year potentially leads to a statistical bias. Thus, the approach adopted here consists of computing for each month the arithmetic mean diurnal cycle from all modelled half-hourly flux data, then scaling up to the whole month, and adding up 12 monthly fluxes for the annual total.

At intensively managed grassland and cropland sites of the NEU network, fertilisation occurred once to several times a year, in which net $\mathrm{NH}_{3}$ emissions typically ensued over one or several weeks, and where elevated ambient $\mathrm{NH}_{3}$ concentrations occurred as a result (e.g. Flechard et al., 2010). Here the modelled (inferential) $\mathrm{NH}_{3}$ flux data from the fertilisation months were not included in the annual deposition total, for any of the four models, the reason being twofold; first, inferential models are primarily deposition models and are not suited to situations with large $\mathrm{NH}_{3}$ emissions e.g. from 
Table 2. Summary of ambient $\mathrm{N}_{\mathrm{r}}$ concentrations across the NEU inferential network (unit: $\mu \mathrm{g} \mathrm{N} \mathrm{m}^{-3}$ ). Data for $\mathrm{NH}_{3}, \mathrm{HNO}_{3}, \mathrm{NH}_{4}^{+}$and $\mathrm{NO}_{3}^{-}$are arithmetic means, minima and maxima of 24 monthly values over the 2007-2008 period. Data for $\mathrm{NO}_{2}$ are calculated from hourly concentration measurements for some sites (see text), or from modelled EMEP $50 \times 50 \mathrm{~km}$ data.

\begin{tabular}{|c|c|c|c|c|c|c|c|c|c|c|c|c|c|c|c|}
\hline \multirow[b]{2}{*}{ Site Code } & \multicolumn{3}{|c|}{$\mathrm{NH}_{3}$} & \multicolumn{3}{|c|}{$\mathrm{HNO}_{3}$} & \multicolumn{3}{|c|}{$\mathrm{NO}_{2}$} & \multicolumn{3}{|c|}{$\mathrm{NH}_{4}^{+}$} & \multicolumn{3}{|c|}{$\mathrm{NO}_{3}^{-}$} \\
\hline & Mean & Min & $\operatorname{Max}$ & Mean & Min & $\operatorname{Max}$ & Mean & Min & $\operatorname{Max}$ & Mean & Min & Max & Mean & Min & Max \\
\hline BE-Bra & 2.28 & 0.03 & 9.43 & 0.46 & 0.10 & 1.28 & 8.98 & 3.96 & 16.69 & 1.34 & 0.04 & 3.89 & 0.87 & 0.01 & 5.21 \\
\hline BE-Vie & 0.37 & 0.09 & 1.51 & 0.13 & 0.01 & 0.31 & 3.38 & na* & na & 0.66 & 0.12 & 1.82 & 0.53 & 0.03 & 3.06 \\
\hline CH-Lae & 1.14 & 0.37 & 2.55 & 0.36 & 0.26 & 0.64 & 2.49 & na & na & 0.95 & 0.43 & 2.12 & 0.60 & 0.18 & 1.58 \\
\hline CZ-BK1 & 0.51 & 0.12 & 0.95 & 0.40 & 0.21 & 0.78 & 2.75 & na & na & 0.89 & 0.12 & 1.38 & 0.40 & 0.22 & 0.76 \\
\hline DE-Hai & 0.57 & 0.06 & 1.64 & 0.22 & 0.11 & 0.52 & 2.65 & na & na & 0.94 & 0.35 & 1.86 & 0.44 & 0.17 & 0.92 \\
\hline DE-Hoe & 1.91 & 0.60 & 3.31 & 0.34 & 0.13 & 0.77 & 2.85 & na & na & 1.02 & 0.39 & 2.57 & 0.50 & 0.20 & 0.99 \\
\hline DE-Tha & 0.62 & 0.11 & 1.37 & 0.28 & 0.17 & 0.60 & 2.82 & na & na & 0.87 & 0.56 & 1.35 & 0.40 & 0.14 & 0.84 \\
\hline DE-Wet & 0.43 & 0.10 & 1.01 & 0.26 & 0.16 & 0.42 & 2.51 & na & na & 0.80 & 0.43 & 1.46 & 0.43 & 0.19 & 0.83 \\
\hline DK-Sor & 1.32 & 0.37 & 4.74 & 0.22 & 0.06 & 0.78 & 2.47 & na & na & 0.72 & 0.16 & 2.21 & 0.77 & 0.01 & 2.94 \\
\hline ES-ES1 & 1.56 & 0.80 & 2.57 & 0.32 & 0.10 & 0.45 & 1.88 & na & na & 0.90 & 0.34 & 1.94 & 0.99 & 0.52 & 1.95 \\
\hline ES-LMa & 1.03 & 0.52 & 2.08 & 0.23 & 0.10 & 0.50 & 0.50 & na & na & 0.46 & 0.15 & 1.64 & 0.38 & 0.18 & 0.84 \\
\hline FI-Hyy & 0.10 & 0.02 & 0.27 & 0.09 & 0.00 & 0.16 & 2.72 & 0.91 & 8.83 & 0.19 & 0.04 & 0.52 & 0.07 & 0.01 & 0.30 \\
\hline FI-Sod & 0.13 & 0.00 & 0.61 & 0.04 & 0.01 & 0.12 & 0.21 & na & na & 0.12 & 0.00 & 0.55 & 0.02 & 0.00 & 0.06 \\
\hline FR-Fon & 0.90 & 0.27 & 2.95 & 0.41 & 0.24 & 0.80 & 2.12 & na & na & 0.96 & 0.38 & 2.20 & 0.68 & 0.32 & 1.59 \\
\hline FR-Hes & 0.89 & 0.26 & 2.42 & 0.35 & 0.21 & 0.61 & 1.99 & na & na & 0.80 & 0.37 & 1.54 & 0.48 & 0.21 & 0.94 \\
\hline FR-LBr & 1.16 & 0.46 & 5.17 & 0.28 & 0.14 & 0.45 & 1.01 & na & na & 0.58 & 0.24 & 1.40 & 0.45 & 0.26 & 0.88 \\
\hline FR-Pue & 0.43 & 0.12 & 0.82 & 0.23 & 0.11 & 0.52 & 0.95 & na & na & 0.46 & 0.19 & 1.19 & 0.30 & 0.14 & 0.60 \\
\hline IT-Col & 0.42 & 0.12 & 0.98 & 0.13 & 0.05 & 0.31 & 1.11 & na & na & 0.47 & 0.16 & 0.83 & 0.25 & 0.06 & 0.48 \\
\hline IT-Ren & 0.26 & 0.05 & 0.50 & 0.09 & 0.03 & 0.21 & 1.10 & 0.30 & 2.18 & 0.52 & 0.03 & 1.29 & 0.26 & 0.02 & 0.62 \\
\hline IT-Ro2 & 1.83 & 0.77 & 7.51 & 0.24 & 0.13 & 0.34 & 0.86 & na & na & 0.86 & 0.51 & 1.53 & 0.51 & 0.30 & 0.78 \\
\hline IT-SRo & 0.84 & 0.30 & 5.71 & 0.31 & 0.11 & 0.51 & 1.12 & na & na & 0.90 & 0.38 & 1.93 & 0.62 & 0.31 & 1.04 \\
\hline NL-Loo & 3.44 & 0.99 & 6.67 & 0.27 & 0.08 & 0.51 & 7.41 & na & na & 1.60 & 0.70 & 5.26 & 0.79 & 0.26 & 1.42 \\
\hline NL-Spe & 3.91 & 1.58 & 6.74 & 0.36 & 0.24 & 0.52 & 5.10 & 2.56 & 9.74 & 1.32 & 0.63 & 2.21 & 0.91 & 0.16 & 1.62 \\
\hline PT-Esp & 1.86 & 0.86 & 4.40 & 0.39 & 0.15 & 0.82 & 2.63 & na & na & 0.84 & 0.45 & 1.73 & 0.51 & 0.04 & 0.93 \\
\hline PT-Mi1 & 0.94 & 0.26 & 2.49 & 0.25 & 0.06 & 0.96 & 0.89 & na & na & 0.69 & 0.24 & 2.10 & 0.38 & 0.20 & 0.88 \\
\hline RU-Fyo & 0.28 & 0.05 & 0.51 & 0.14 & 0.07 & 0.29 & 0.50 & na & na & 0.45 & 0.18 & 0.79 & 0.15 & 0.06 & 0.31 \\
\hline SE-Nor & 0.22 & 0.02 & 0.68 & 0.05 & 0.01 & 0.17 & 0.66 & na & na & 0.25 & 0.03 & 1.02 & 0.10 & 0.01 & 0.31 \\
\hline SE-Sk2 & 0.16 & 0.02 & 0.95 & 0.06 & 0.02 & 0.12 & 0.63 & na & na & 0.21 & 0.01 & 0.64 & 0.10 & 0.01 & 0.45 \\
\hline UK-Gri & 0.27 & 0.04 & 1.47 & 0.12 & 0.02 & 0.47 & 0.48 & na & na & 0.39 & 0.02 & 1.76 & 0.29 & 0.03 & 1.49 \\
\hline Mean $(F)$ & 1.03 & 0.32 & 2.83 & 0.24 & 0.11 & 0.51 & 2.15 & 1.25 & 6.92 & 0.73 & 0.26 & 1.75 & 0.45 & 0.15 & 1.19 \\
\hline DE-Meh & 1.48 & 0.21 & 4.08 & 0.29 & 0.18 & 0.48 & 2.67 & na & na & 1.12 & 0.03 & 1.66 & 0.55 & 0.20 & 0.92 \\
\hline ES-VDA & 0.90 & 0.07 & 5.28 & 0.12 & 0.04 & 0.49 & 0.83 & na & na & 0.70 & 0.09 & 3.42 & 0.27 & 0.02 & 0.75 \\
\hline FI-Lom & 0.09 & 0.01 & 0.31 & 0.03 & 0.00 & 0.26 & 0.19 & 0.00 & 0.48 & 0.21 & 0.00 & 0.65 & 0.02 & 0.00 & 0.07 \\
\hline HU-Bug & 2.27 & 0.71 & 5.16 & 0.30 & 0.12 & 0.48 & 2.61 & 1.53 & 4.65 & 1.25 & 0.63 & 2.40 & 0.46 & 0.15 & 1.03 \\
\hline IT-Amp & 0.56 & 0.19 & 1.20 & 0.14 & 0.07 & 0.36 & 1.11 & na & na & 0.48 & 0.25 & 1.05 & 0.22 & 0.10 & 0.40 \\
\hline IT-MBo & 0.74 & 0.14 & 1.84 & 0.22 & 0.12 & 0.38 & 1.77 & na & na & 0.74 & 0.06 & 2.18 & 0.47 & 0.02 & 1.13 \\
\hline NL-Hor & 2.49 & 0.77 & 5.28 & 0.33 & 0.12 & 0.52 & 9.45 & na & na & 1.37 & 0.54 & 2.97 & 0.94 & 0.43 & 1.85 \\
\hline PL-wet & 0.95 & 0.24 & 2.39 & 0.25 & 0.02 & 0.41 & 1.45 & na & na & 1.09 & 0.42 & 2.85 & 0.46 & 0.12 & 1.13 \\
\hline UK-AMo & 0.63 & 0.30 & 1.22 & 0.09 & 0.03 & 0.23 & 1.45 & 0.71 & 2.46 & 0.38 & 0.09 & 0.97 & 0.23 & 0.05 & 0.56 \\
\hline Mean (SN) & 1.12 & 0.29 & 2.97 & 0.20 & 0.08 & 0.40 & 2.39 & 0.75 & 2.53 & 0.82 & 0.24 & 2.02 & 0.40 & 0.12 & 0.87 \\
\hline CH-Oe1 & 2.68 & 0.71 & 6.51 & 0.41 & 0.20 & 0.71 & 10.89 & 5.53 & 19.01 & 1.15 & 0.50 & 2.05 & 0.66 & 0.34 & 1.25 \\
\hline DE-Gri & 0.70 & 0.12 & 1.28 & 0.36 & 0.17 & 1.22 & 2.82 & na & na & 0.89 & 0.49 & 2.94 & 0.47 & 0.17 & 1.89 \\
\hline DK-Lva & 1.26 & 0.27 & 3.71 & 0.20 & 0.02 & 0.35 & 2.47 & na & na & 0.56 & 0.22 & 1.37 & 0.79 & 0.05 & 3.08 \\
\hline FR-Lq2 & 1.11 & 0.37 & 1.81 & 0.14 & 0.06 & 0.48 & 0.65 & na & na & 0.44 & 0.19 & 1.36 & 0.25 & 0.11 & 0.70 \\
\hline IE-Ca2 & 1.56 & 0.81 & 3.04 & 0.10 & 0.04 & 0.22 & 0.75 & na & na & 0.59 & 0.10 & 1.87 & 0.33 & 0.11 & 1.08 \\
\hline IE-Dri & 2.03 & 0.72 & 4.94 & 0.07 & 0.01 & 0.17 & 0.45 & na & na & 0.53 & 0.05 & 2.24 & 0.29 & 0.05 & 0.93 \\
\hline NL-Ca1 & 5.93 & 3.10 & 10.79 & 0.41 & 0.25 & 0.98 & 9.45 & na & na & 1.66 & 0.35 & 4.95 & 1.10 & 0.09 & 2.16 \\
\hline UK-EBu & 1.08 & 0.32 & 2.17 & 0.12 & 0.04 & 0.24 & 0.85 & 0.20 & 1.96 & 0.38 & 0.08 & 0.87 & 0.26 & 0.05 & 0.59 \\
\hline Mean (G) & 2.04 & 0.80 & 4.28 & 0.23 & 0.10 & 0.55 & 3.54 & 2.87 & 10.48 & 0.78 & 0.25 & 2.21 & 0.52 & 0.12 & 1.46 \\
\hline BE-Lon & 3.93 & 1.00 & 14.46 & 0.29 & 0.05 & 0.47 & 4.31 & na & na & 1.08 & 0.04 & 2.58 & 0.73 & 0.09 & 2.41 \\
\hline DE-Geb & 4.14 & 0.50 & 13.41 & 0.25 & 0.15 & 0.33 & 2.65 & na & na & 1.41 & 0.05 & 6.73 & 0.56 & 0.18 & 1.18 \\
\hline DE-Kli & 1.32 & 0.24 & 2.49 & 0.31 & 0.14 & 0.49 & 2.82 & na & na & 1.05 & 0.61 & 2.56 & 0.53 & 0.18 & 1.94 \\
\hline DK-Ris & 4.32 & 0.15 & 14.26 & 0.14 & 0.02 & 0.27 & 2.47 & na & na & 0.58 & 0.01 & 1.66 & 0.44 & 0.07 & 0.90 \\
\hline FR-Gri & 3.16 & 0.92 & 10.24 & 0.45 & 0.18 & 0.98 & 4.99 & 1.95 & 11.01 & 0.94 & 0.26 & 2.56 & 0.76 & 0.30 & 2.01 \\
\hline IT-BCi & 7.18 & 2.58 & 21.63 & 0.38 & 0.22 & 0.82 & 1.26 & na & na & 3.12 & 0.37 & 14.81 & 0.73 & 0.33 & 1.23 \\
\hline IT-Cas & 3.42 & 1.30 & 5.91 & 0.44 & 0.22 & 0.86 & 1.12 & 0.54 & 1.61 & 2.38 & 0.32 & 4.81 & 1.43 & 0.35 & 3.05 \\
\hline UA-Pet & 2.50 & 0.62 & 5.35 & 0.36 & 0.18 & 0.68 & 1.00 & na & na & 1.44 & 0.34 & 9.52 & 0.48 & 0.21 & 0.76 \\
\hline UK-ESa & 2.92 & 0.80 & 13.57 & 0.12 & 0.06 & 0.20 & 2.39 & na & na & 0.71 & 0.15 & 3.18 & 0.24 & 0.10 & 0.41 \\
\hline Mean (C) & 3.65 & 0.90 & 11.26 & 0.30 & 0.13 & 0.57 & 2.56 & 1.25 & 6.31 & 1.41 & 0.24 & 5.38 & 0.66 & 0.20 & 1.54 \\
\hline
\end{tabular}

* "na": not available. 
applied fertiliser, but to background conditions (Flechard et al., 2010); the special case of fertiliser- or manure-induced $\mathrm{NH}_{3}$ losses requires a different kind of modelling approach (e.g. Genermont and Cellier, 1997) and is not considered here. Second, applying an inferential model to months when fertilisation occurred would result in a large deposition flux (due to the elevated $\mathrm{NH}_{3}$ concentration) when net emission actually occurred, thus over-estimating annual deposition. The importance of field $\mathrm{NH}_{3}$ emissions by agricultural management events relative to background exchange is discussed in Sect. 3.3 by comparing model results with actual longterm flux datasets

\section{Results and discussion}

\subsection{Model evaluation for key exchange variables}

\subsubsection{Gap-filling of friction velocity data}

Measured values of $u_{*}$ from EC datasets were used preferentially for flux modelling whenever possible; the prediction of $u_{*}$ based on an assumed value of $z_{0}$ for vegetation and on meteorological conditions (Sect. A3, Supplement) was used only when measured turbulence data were missing. This represented on average $21 \%$ of the time across the network, although $u_{*}$ data capture was close to $100 \%$ at some sites and less than 60\% at others for the period 2007-2008.

For the gap-filling of $u_{*}$, the model base runs used measured values of $h_{\mathrm{c}}$ to calculate $z_{0}$, while inferential models within the framework of CTMs would normally predict $u_{*}$ from their own default $h_{\mathrm{c}}$ values. The discrepancies in modelled $u_{*}$ are shown in Fig. 1, with the different default values of $h_{\mathrm{c}}$ leading to different $u_{*}$ estimates between models across the sites (Fig. 1a). The actual use of measured $h_{\mathrm{c}}$ naturally suppressed these differences between models (Fig. 1b), with residual inter-model discrepancies being due to slightly different stability correction functions in the four models. Not surprisingly, the use of measured $h_{\mathrm{c}}$ (as opposed to model defaults) also considerably improved the agreement between modelled and measured $u_{*}$, and reduced the scatter in the relationship (Fig. 1b), even if there was a marked tendency to overestimate $u_{*}$ over forests at the higher end of the scale. The three forest sites whose mean measured $u_{*}$ was around $0.65 \mathrm{~m} \mathrm{~s}^{-1}$ (DE-Hai, DE-Wet, DK-Sor), and whose mean modelled $u_{*}$ were $0.76,0.83$ and $0.91 \mathrm{~m} \mathrm{~s}^{-1}$, respectively, were $33 \mathrm{~m}$ tall beech, $22 \mathrm{~m}$ tall spruce and $31 \mathrm{~m}$ tall beech forests, respectively. The other forest site whose mean $u_{*}\left(0.51 \mathrm{~m} \mathrm{~s}^{-1}\right)$ was largely overestimated $\left(0.75 \mathrm{~m} \mathrm{~s}^{-1}\right)$ was NL-Spe, a mixed species $32 \mathrm{~m}$ tall stand, dominated in the near field by Douglas fir. These four forests have comparatively large maximum leaf area indices, in the range 5$11 \mathrm{~m}^{2} \mathrm{~m}^{-2}$ (Table 1), which may reduce frictional retardation of wind. Further, the underlying model assumption that $z_{0}$ increases linearly with $h_{\mathrm{c}}$ (with $z_{0}$ being normally calculated as one tenth of $h_{\mathrm{c}}$ in CBED, EMEP-03 and IDEM) is probably not valid, depending on canopy structure and leaf morphology, and $z_{0}$ values of $3 \mathrm{~m}$ for the aforesaid $30 \mathrm{~m}$ tall forests are therefore unrealistic. Another explanation is that most anemometers over forest are operated within the roughness sublayer, where wind speed is larger than would be predicted on the basis of the logarithmic wind profile, thus leading to larger modelled $u_{*}$ values. This may be different for CTMs where the reference height is higher (e.g. $50 \mathrm{~m}$ ).

Note that in this study, "modelled" $u_{*}$ means a value derived from the measured wind speeds and stability functions; values of $u_{*}$ in the regional application of these models depend on the NWP model and sub-grid treatment, and might be quite different. While the CTMs aim to capture $h_{\mathrm{c}}, u_{*}$ and other features relevant for dry deposition over representative landscapes, the comparison shown in Fig. 1a is only fully meaningful to the extent that the limited number of NEU sites may be considered as statistically representative of their land-use class.

\subsubsection{Stomatal conductance}

Stomatal conductance $\left(G_{\mathrm{s}}=\right.$ inverse of bulk stomatal resistance to water vapour) is controlled by leaf surface area and by PAR, as well as temperature, soil moisture and ambient relative humidity, and therefore strong seasonal cycles are expected in European conditions. The four models do show some temporal correlation with respect to $G_{\mathrm{s}}$ as shown in Fig. 2. Over forests, the mean daytime $G_{\mathrm{s}}$ was modelled to be generally largest in summer, with values of typically 5 to $10 \mathrm{~mm} \mathrm{~s}^{-1}$. There were clear discrepancies between models in summer for forests, with $G_{\mathrm{s}}$ in CBED and IDEM typically a factor of two larger than in CDRY and EMEP-03 for coniferous forests, but the agreement was much better for deciduous forests (e.g. DE-Hai, DK-Sor, FR-Fon, FR-Hes). During the other seasons, the IDEM model stands out over the coniferous sites, with mean daytime $G_{\mathrm{s}}$ values of typically $10 \mathrm{~mm} \mathrm{~s}^{-1}$, almost regardless of the season except in the more northerly regions, while the other three models are rather consistent and show reduced values compared with summer. At selected mediterranean or Southern European coniferous sites, where summer heat stress and drought reduce stomatal exchange in summer, $G_{\mathrm{s}}$ values predicted by IDEM are actually marginally larger in winter than in summer (e.g. ES-ES1, FR-LBr, IT-SRo).

Over short vegetation, the seasonal picture is much more pronounced than in the NEU forest network, in which evergreen forests were dominant. Strong seasonal cycles in LAI in $\mathrm{SN}, \mathrm{G}$ and $\mathrm{C}$ land uses, as well as in solar radiation, drive the annual variations in $G_{s}$, with logically annual maxima in summer (Fig. 2). The IDEM model predicts much larger (a factor 2 to 4) summer daytime stomatal conductances, typically $15-30 \mathrm{~mm} \mathrm{~s}^{-1}$, than the other models with typically $5-10 \mathrm{~mm} \mathrm{~s}^{-1}$; IDEM also tends to predict higher autumn $G_{\mathrm{s}}$ than the other models, especially for crops. By contrast the 

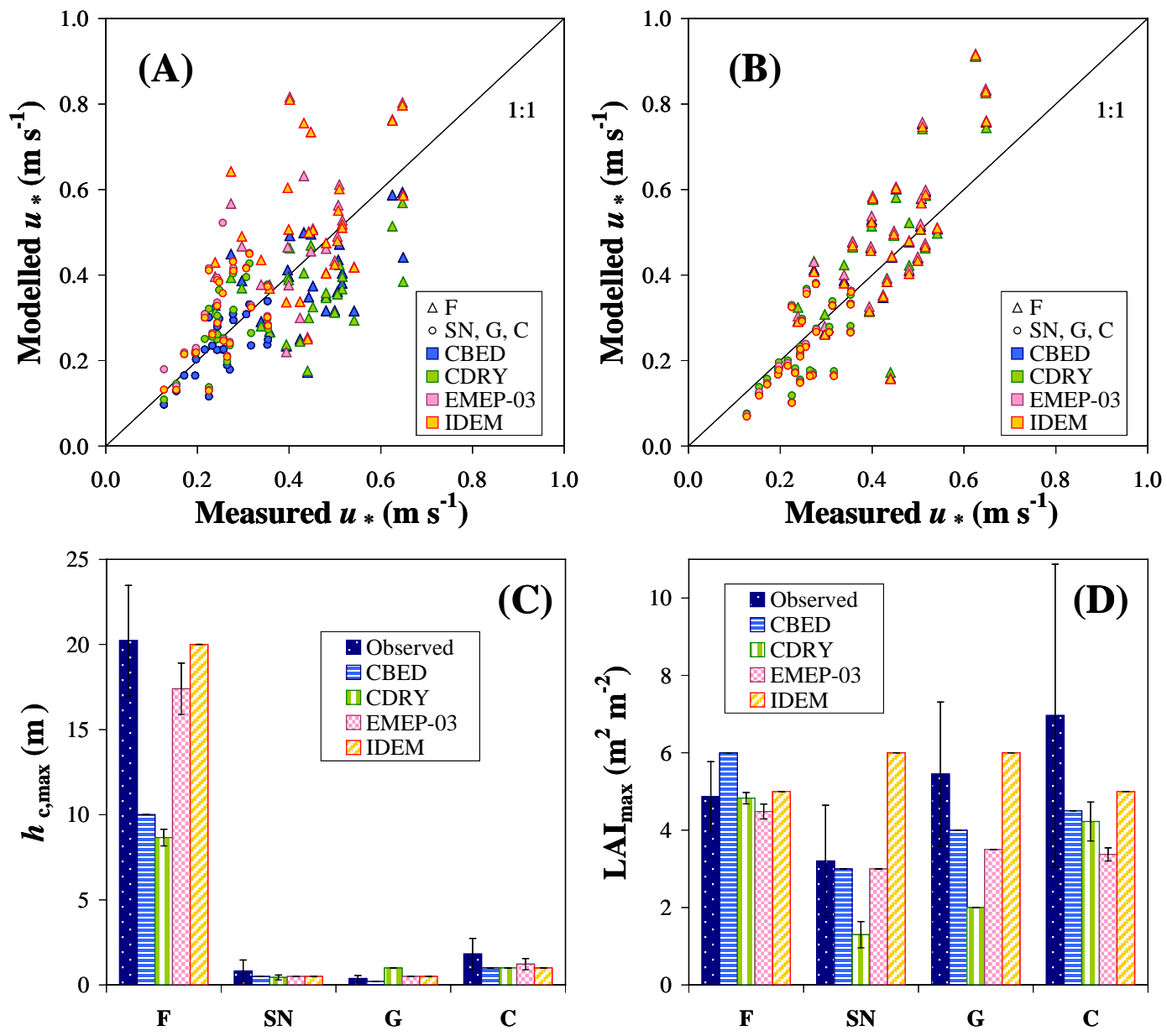

Fig. 1. Comparison of measured $u_{*}$ (long-term means at each observation site) with inferential model estimates, using as input either model default values of $h_{\mathrm{c}}(\mathbf{A})$ or measured $h_{\mathrm{c}}$ at each site (B). Panels (A) and (D): comparison of mean observations and model default values of $h_{\mathrm{c}}$ and LAI for the different land use types (F: forests; SN: semi-natural; G: grasslands; C: croplands). Note that the CDRY model uses tabulated ecosystem-specific values of $z_{0}$, and does not require hc as a predictor of z0; thus, for comparabilitys sake, the hc values presented for CDRY in Fig. 1C were actually calculated by multiplying model $z_{0}$ by 10 , since the other three models all use $z_{0}=h_{\mathrm{c}} / 10$.

EMEP-03 model yields the smallest summer $G_{\mathrm{s}}$ values, particularly in crops in spring and summer, owing in part to a rather short predicted growing season, typically 100 days, outside of which the soil is assumed to be bare ( $\mathrm{LAI}=0$, $G_{\mathrm{s}}=0$ ). The four models are otherwise roughly consistent during the rest of the year, with residual stomatal exchange in spring and autumn and a near zero $G_{\mathrm{s}}$ in winter.

\subsubsection{Trace gas and aerosol deposition velocities}

Deposition velocities were calculated for the height of the DELTA system inlets in order to infer exchange fluxes directly from DELTA concentrations (Eq. 1), but since sampling- and canopy- heights varied between sites, and for comparability's sake, we present in this section mean $V_{\mathrm{d}}$ data evaluated at a standard height of $3 \mathrm{~m}$ above $d+z_{0}$ for all F, SN, G and C ecosystems (Fig. 3). With the exception of $\mathrm{NO}_{2}$, for the $\mathrm{N}_{\mathrm{r}}$ species considered here, $V_{\mathrm{d}}$ was substantially larger over forests than over short vegetation, regardless of the model, due to the reduced aerodynamic resistance $R_{\mathrm{a}}$ for rougher forest surfaces (over the same vertical path of $3 \mathrm{~m}$ ). For $\mathrm{NO}_{2}$ this had no noticeable effect on $V_{\mathrm{d}}$, as $R_{\mathrm{c}}$ made up the bulk of the total resistance to dry deposition, with uptake being largely limited to the stomatal pathway in the four models.

For $\mathrm{HNO}_{3}$ over short vegetation, the mean $V_{\mathrm{d}}$ was of the order of $10-12 \mathrm{~mm} \mathrm{~s}^{-1}$ and very similar between models since the non-stomatal resistance was generally considered to be small, though not necessarily negligible (CDRY, IDEM), and $V_{\mathrm{d}}$ could be approximated to $1 /\left(R_{\mathrm{a}}+R_{\mathrm{b}}\right)$ as the sum of atmospheric resistances was much larger than $R_{\mathrm{c}}$. The spread in mean $V_{\mathrm{d}}$ values for each vegetation type (F, SN, G, C), as shown by the range of mean site $V_{\mathrm{d}}$ values from the 5 th to the 95th percentile in Fig. 3, thus reflected the range of mean windspeeds measured at the different sites, so that mean $V_{\mathrm{d}}$ could exceed $15 \mathrm{~mm} \mathrm{~s}^{-1}$ at the windier sites. Over forests, 


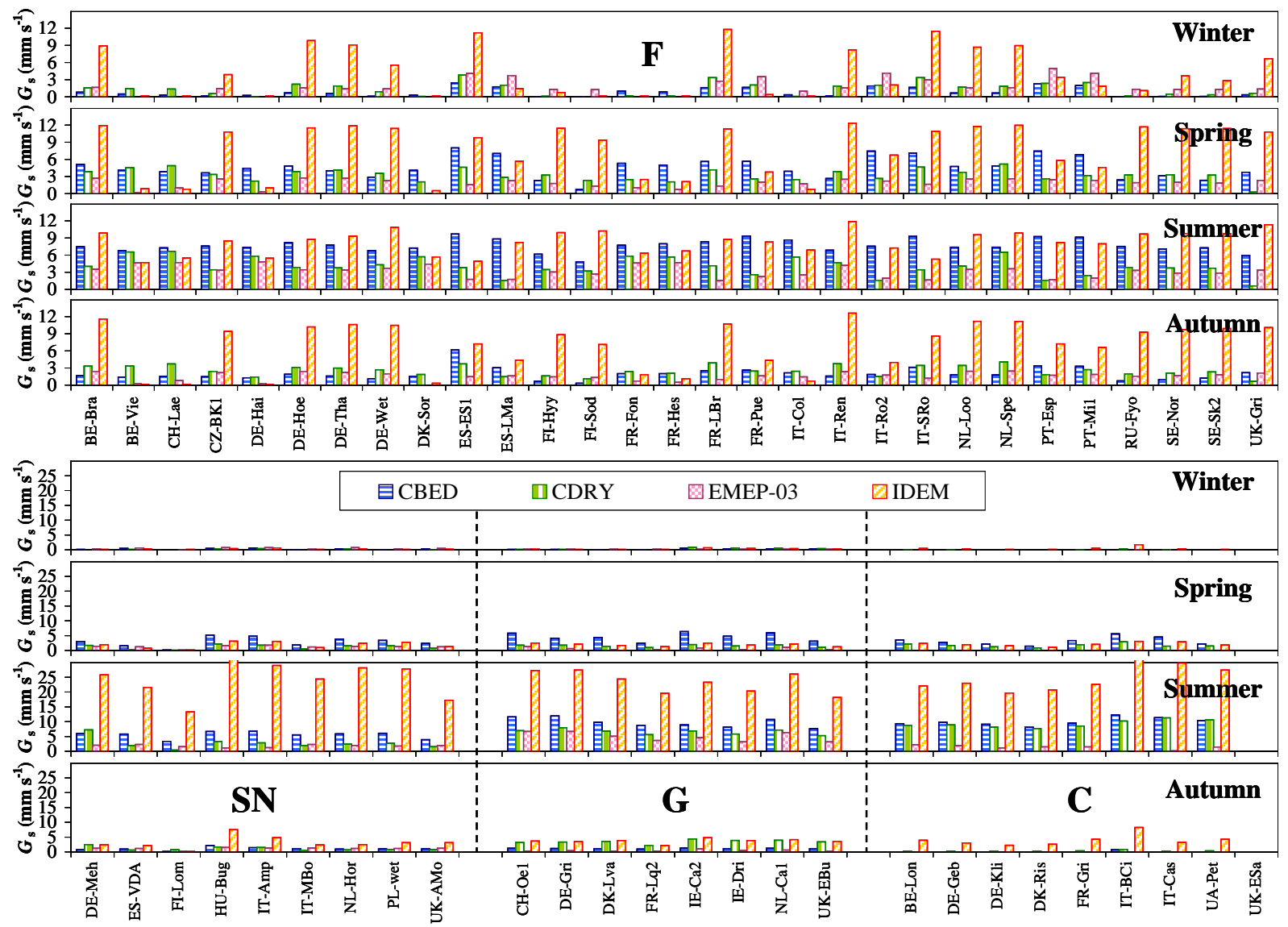

Fig. 2. Comparison of mean modelled daytime bulk stomatal conductances from the four inferential schemes.
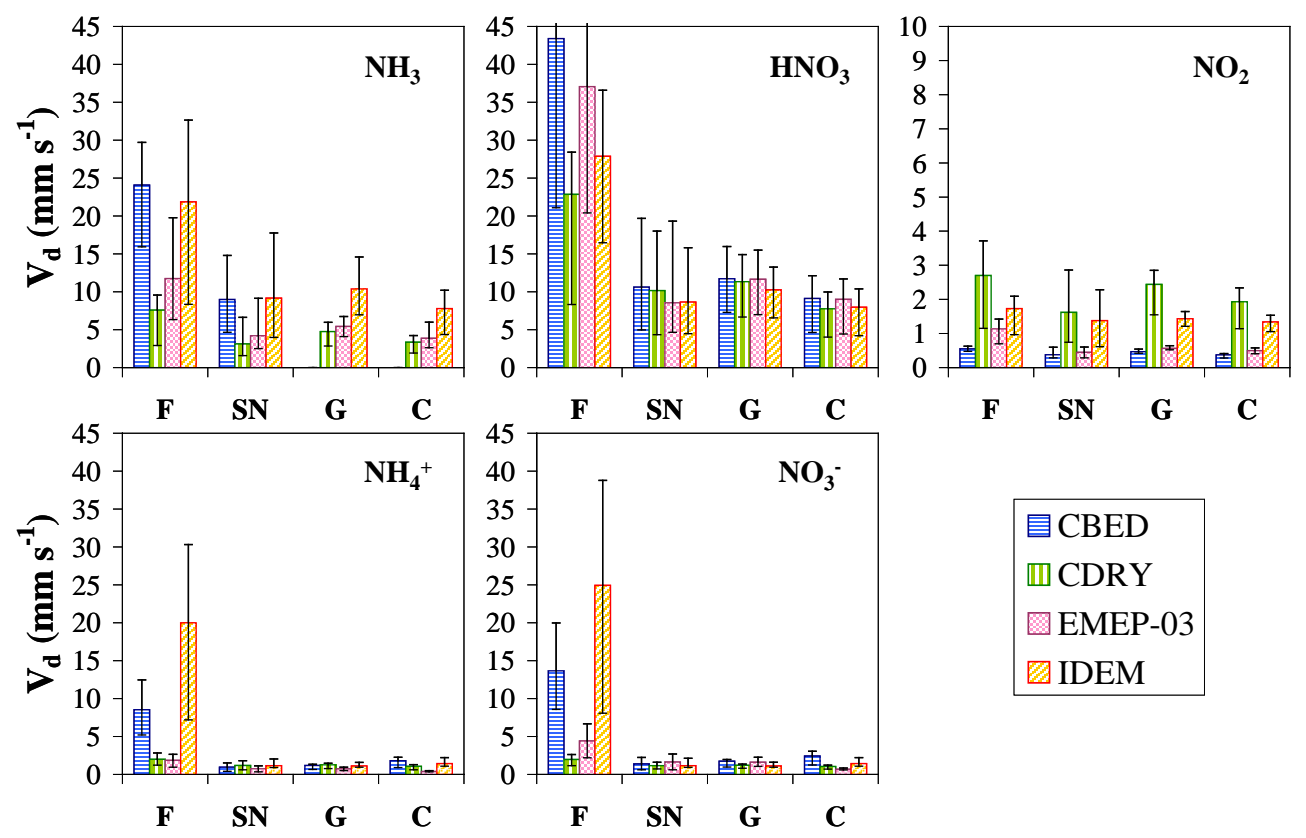

F SN G C

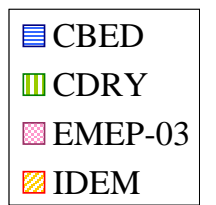

Fig. 3. Overview of mean modelled deposition velocities (evaluated at $d+z_{0}+3 \mathrm{~m}$ for all sites) for dominant atmospheric $\mathrm{N}_{\mathrm{r}}$ species. Data are medians and 5th and 95th percentiles across the sites of mean $V_{\mathrm{d}}$ values at each site. Note the different scale on the vertical axis for $\mathrm{NO}_{2}$. 
by contrast, mean $V_{\mathrm{d}}$ for $\mathrm{HNO}_{3}$ was typically $25-35 \mathrm{~mm} \mathrm{~s}^{-1}$, with the mean $R_{\mathrm{a}}$ at $3 \mathrm{~m}$ above $d+z_{0}$ being of the order of a few s m${ }^{-1}$. Here, the differences between models in $R_{\mathrm{c}}$ for $\mathrm{HNO}_{3}$ (Sect. 2.1.1) became significant, so that the mean $V_{\mathrm{d}}$ across sites in CDRY and IDEM was substantially smaller $\left(\sim 25 \mathrm{~mm} \mathrm{~s}^{-1}\right)$ than in CBED and EMEP-03 $\left(>35 \mathrm{~mm} \mathrm{~s}^{-1}\right)$.

The most significant absolute inter-model differences, however, were found for $\mathrm{NH}_{3}$ for all vegetation types, and for aerosol $\mathrm{NH}_{4}^{+}$and $\mathrm{NO}_{3}^{-}$over forests (Fig. 3). For unfertilised vegetation $(\mathrm{F}, \mathrm{SN}), V_{\mathrm{d}}$ for $\mathrm{NH}_{3}$ was a factor 2-3 larger in CBED and IDEM than in CDRY and EMEP-03. The CDRY scheme systematically predicted the smallest $V_{\mathrm{d}}$ of the four models for $\mathrm{NH}_{3}$ due to a generally much larger non-stomatal resistance, which was taken to be equal to that for $\mathrm{SO}_{2}$. There was a relatively small spread of mean site $V_{\mathrm{d}}$ values in CBED for $\mathrm{F}$ and $\mathrm{SN}$, compared with EMEP-03 and IDEM, as the CBED scheme used a constant $R_{\mathrm{c}}$ of $20 \mathrm{~s} \mathrm{~m}^{-1}$ for unfertilised vegetation, while in the other models variations in $R_{\mathrm{c}}$ were controlled by $\mathrm{RH}, T$ and sometimes by the ratio of $\mathrm{SO}_{2}$ to $\mathrm{NH}_{3}$ ambient concentrations. Remarkably, however, the mean $V_{\mathrm{d}}$ for $\mathrm{NH}_{3}$ across sites was almost identical in CBED and IDEM for F and SN. There are very few long-term micrometeorological $\mathrm{NH}_{3}$ flux datasets over (European) forests, from which comprehensive and robust parameterisations may be derived, with the bulk of $\mathrm{NH}_{3}$ flux measurements stemming from mainly coniferous stands in the high $\mathrm{N}$ environment of The Netherlands (Wyers and Erisman, 1998), Belgium (Neirynck et al., 2005, 2007; Neirynck and Ceulemans, 2008) and Denmark (Andersen et al., 1999) (see also Zhang et al., 2010 and Massad, 2010, for reviews), and this is clearly reflected in the wide range of deposition velocities provided by the different models.

Over fertilised systems $(\mathrm{G}, \mathrm{C})$, no $V_{\mathrm{d}}$ is provided for $\mathrm{NH}_{3}$ in CBED since this uses a compensation point approach, but for the other three models the same hierarchy in $V_{\mathrm{d}}$ estimates is found as for $\mathrm{F}$ and $\mathrm{SN}$, with IDEM providing the largest values, about $10 \mathrm{~mm} \mathrm{~s}^{-1}$ ) and CDRY the smallest, around $5 \mathrm{~mm} \mathrm{~s}^{-1}$ (Fig. 3).

Aerosol $\mathrm{N}_{\mathrm{r}}$ deposition velocities were predicted to be very small for short vegetation, typically $2-3 \mathrm{~mm} \mathrm{~s}^{-1}$, with little variation between models. All models consistently showed slightly larger $V_{\mathrm{d}}$ for $\mathrm{NO}_{3}^{-}$than for $\mathrm{NH}_{4}^{+}$, reflecting the larger fraction of $\mathrm{NO}_{3}^{-}$found in the coarse aerosol mode compared with $\mathrm{NH}_{4}^{+}$. By contrast to short vegetation, $V_{\mathrm{d}}$ estimates over forests varied widely different between the four routines, with theoretical (Slinn-type) models (CDRY, EMEP03 ) providing similar estimates of the order of $2-5 \mathrm{~mm} \mathrm{~s}^{-1}$, and the more empirical, measurement-based or simplified models (CBED, IDEM) yielding much larger estimates (typically $10-25 \mathrm{~mm} \mathrm{~s}^{-1}$ ). Publications from the last 10 years have also demonstrated that, over forests, deposition velocities for particles in the size range $0.1-1 \mu \mathrm{m}$, which contain most of the atmospheric $\mathrm{N}_{\mathrm{r}}$, are much larger than would be expected on the basis of theory, with values of typically
$10 \mathrm{~mm} \mathrm{~s}^{-1}$ (Gallagher et al., 1997) or even $50-100 \mathrm{~mm} \mathrm{~s}^{-1}$ (Wolff et al., 2009). Gallagher et al. (2002) further showed from a compilation of published $V_{\mathrm{d}}$ data for small aerosols $(0.1-0.2 \mu \mathrm{m})$ that $V_{\mathrm{d}}$ was strongly dependent on the roughness of vegetation and that measured $V_{\mathrm{d}}$ was typically a factor 10 larger than Slinn-type models, not only for forests but across the range of $z_{0}$ values from the various datasets over heathland, grassland and arable land. However, it should also be noted that many of the larger deposition velocities (e.g. Gallagher et al., 1997) have been measured over Speulder forest (NL-Spe in Table 1), which is a Douglas fir forests with a projected LAI $>10$; this canopy is far denser than the typical Scots pine or Norway spruce canopies (LAI $\sim 3-5$ ), and hence large $V_{\mathrm{d}}$ would be expected (Petroff et al., 2008a, b). Further, apparent emission fluxes are common in flux datasets, and there are significant difficulties in interpreting how far such data are real or represent artifacts (Pryor et al., 2007, 2008a, b). Emerging evidence from chemically resolved particle flux measurements suggests that the volatilisation of $\mathrm{NH}_{4} \mathrm{NO}_{3}$ during deposition may increase effective deposition rates of these compounds and that effective deposition rates for $\mathrm{NO}_{3}^{-}$may therefore be significantly larger than for thermodynamically stable $\mathrm{SO}_{4}^{2-}$ (Fowler et al., 2009). Such large model/measurement discrepancies, as well as the large differences between models (Fig. 3), hint at much uncertainty regarding aerosol $V_{\mathrm{d}}$, especially to forests, where the large roughness may potentially mean much larger aerosol dry deposition than assumed heretofore.

\subsection{Dry deposition of $\mathrm{N}_{\mathrm{r}}$ to European ecosystems}

Modelled annual dry deposition fluxes of atmospheric $\mathrm{N}_{\mathrm{r}}$ are summarised in Table 3 and Fig. 4. We approximate $\mathrm{N}_{\mathrm{r}}$ dry deposition as the sum of the dominant inorganic species, i.e. gas $\mathrm{NH}_{3}, \mathrm{HNO}_{3}$ and $\mathrm{NO}_{2}$ and aerosol $\mathrm{NH}_{4}^{+}$and $\mathrm{NO}_{3}^{-}$ fluxes, as no data were available for organic $\mathrm{N}_{\mathrm{r}}$. As expected from the model inter-comparison for $V_{\mathrm{d}}$ (Fig. 3), the annual $\mathrm{N}_{\mathrm{r}}$ dry deposition estimates are very model dependent, with variations between the largest and smallest estimates at any given site reaching typically a factor 2 to 3 (Fig. 4). There was nonetheless a strong correlation across the sites between models, which was logically driven by the measured atmospheric concentrations and meteorology.

Note that the results discussed hereafter were obtained from model base runs as outlined earlier (Sect. 2.3.1), and detailed in Sect. A2-A5 and Table A2 of the Supplement. Alternative runs shown therein (Fig. A3) demonstrate that the choice of measured or model default LAI and $h_{\mathrm{c}}$ as inputs to the models has a significant impact on annual fluxes, generally of the order of \pm 10 to $20 \%$ of the base run flux, but sometimes reaching $\pm 50 \%$. Likewise, the use of temperature and relative humidity data estimated at canopy level $\left(d+z_{0}{ }^{\prime}\right)$ where exchange processes take place, rather than data in the ambient air above the canopy (base run), has a very large impact on $\mathrm{NH}_{3}$ emissions by stomata of grass and crops in 
Table 3. Summary of modelled annual dry deposition fluxes to the sites of the NEU inferential network (unit: $\mathrm{kg} \mathrm{Nha}^{-1} \mathrm{yr}^{-1}$ ), averaged over the two years 2007-2008. A minus “-” sign denotes net deposition; positive numbers for $\mathrm{NH}_{3}$ in $\mathrm{CBED}$ indicate a net emission.

\begin{tabular}{|c|c|c|c|c|c|c|c|c|c|c|c|c|c|c|c|c|c|c|c|c|}
\hline \multirow[b]{2}{*}{ Site } & \multicolumn{5}{|c|}{ CBED } & \multicolumn{5}{|c|}{ CDRY } & \multicolumn{5}{|c|}{ EMEP } & \multicolumn{5}{|c|}{ IDEM } \\
\hline & $\mathrm{NH}_{3}$ & $\mathrm{HNO}_{3}$ & $\mathrm{NO}_{2}$ & $\mathrm{NH}_{4}^{+}$ & $\mathrm{NO}_{3}^{-}$ & $\mathrm{NH}_{3}$ & $\mathrm{HNO}_{3}$ & $\mathrm{NO}_{2}$ & $\mathrm{NH}_{4}^{+}$ & $\mathrm{NO}_{3}^{-}$ & $\mathrm{NH}_{3}$ & $\mathrm{HNO}_{3}$ & $\mathrm{NO}_{2}$ & $\mathrm{NH}_{4}^{+}$ & $\mathrm{NO}_{3}^{-}$ & $\mathrm{NH}_{3}$ & $\mathrm{HNO}_{3}$ & $\mathrm{NO}_{2}$ & $\mathrm{NH}_{4}^{+}$ & $\mathrm{NO}_{3}^{-}$ \\
\hline BE-Bra & -16.7 & -6.6 & -2.5 & -4.2 & -4.3 & -5.3 & -3.6 & -8.0 & -1.0 & -0.7 & -7.4 & -6.5 & -2.7 & -1.0 & -1.5 & -12.6 & -4.3 & -7.9 & -6.6 & -5.3 \\
\hline BE-Vie & -3.7 & -2.4 & -1.3 & -2.2 & -3.0 & -1.5 & -1.4 & -4.6 & -0.5 & -0.4 & -2.1 & -2.2 & -0.4 & -0.4 & -0.3 & -3.2 & -1.6 & -1.3 & -3.9 & -4.3 \\
\hline $\mathrm{CH}-\mathrm{Lae}$ & -7.9 & -4.3 & -0.9 & -2.6 & -2.6 & -3.1 & -2.4 & -2.9 & -0.6 & -0.4 & -3.5 & -3.7 & -0.1 & -0.5 & -0.6 & -6.3 & -2.9 & -0.9 & -6.1 & -4.8 \\
\hline CZ-BK1 & -3.4 & -4.2 & -1.0 & -2.2 & -1.6 & -1.3 & -2.8 & -2.9 & -0.5 & -0.2 & -2.6 & -3.2 & -0.3 & -0.6 & -0.6 & -3.2 & -3.0 & -2.4 & -3.9 & -2.1 \\
\hline DE-Hai & -4.8 & -4.6 & -1.0 & -4.3 & -3.2 & -1.4 & -2.3 & -2.4 & -0.9 & -0.4 & -2.4 & -4.2 & -0.1 & -0.5 & -0.4 & -4.4 & -3.0 & -1.1 & -5.7 & -3.4 \\
\hline DE-Hoe & -14.8 & -4.4 & -1.3 & -3.3 & -2.6 & -5.4 & -2.6 & -3.2 & -0.8 & -0.4 & -5.5 & -4.3 & -0.3 & -1.0 & -1.2 & -9.6 & -3.0 & -3.2 & -4.5 & -2.5 \\
\hline DE-Tha & -5.6 & -4.3 & -1.2 & -2.9 & -2.2 & -2.2 & -2.7 & -3.1 & -0.7 & -0.4 & -3.2 & -4.0 & -0.2 & -0.7 & -0.8 & -4.5 & -3.0 & -2.8 & -3.6 & -2.0 \\
\hline DE-Wet & -3.7 & -4.5 & -0.9 & -3.2 & -2.8 & -1.7 & -2.7 & -4.2 & -0.8 & -0.5 & -2.5 & -3.6 & -0.1 & -0.9 & -1.3 & -3.9 & -2.8 & -2.4 & -5.3 & -3.7 \\
\hline DK-Sor & -9.8 & -3.5 & -1.0 & -3.1 & -5.3 & -3.3 & -1.8 & -2.3 & -0.7 & -0.6 & -4.5 & -3.3 & 0.0 & -0.3 & -0.4 & -7.1 & -2.2 & -1.0 & -3.4 & -4.7 \\
\hline ES-ES1 & -12.6 & -4.5 & -1.3 & -2.5 & -4.3 & -4.3 & -3.0 & -1.8 & -0.6 & -0.6 & -4.9 & -4.5 & 0.0 & -0.7 & -1.8 & -8.0 & -3.3 & -1.8 & -3.1 & -3.8 \\
\hline ES-LMa & -6.2 & -1.9 & -0.2 & -0.8 & -1.1 & -1.1 & -0.6 & -0.2 & -0.2 & -0.1 & -2.2 & -1.9 & 0.0 & -0.2 & -0.4 & -2.5 & -1.4 & -0.3 & -0.7 & -0.6 \\
\hline FI-Hyy & -0.8 & -1.1 & -0.4 & -0.6 & -0.3 & -0.3 & -0.7 & -2.8 & -0.1 & -0.1 & -0.4 & -0.8 & -1.0 & -0.1 & -0.1 & -0.7 & -0.7 & -1.6 & -1.1 & -0.4 \\
\hline FI-Sod & -1.0 & -0.5 & -0.1 & -0.3 & -0.1 & -0.4 & -0.4 & -0.2 & -0.1 & 0.0 & -0.5 & -0.2 & 0.0 & -0.1 & 0.0 & -1.0 & -0.3 & -0.2 & -0.5 & -0.1 \\
\hline FR-Fon & -6.0 & -4.3 & -1.0 & -2.8 & -3.2 & -1.7 & -2.2 & -1.6 & -0.6 & -0.4 & -2.7 & -4.2 & 0.0 & -0.3 & -0.5 & -4.4 & -3.1 & -1.0 & -3.8 & -3.2 \\
\hline FR-Hes & -5.8 & -3.7 & -0.8 & -2.2 & -2.1 & -1.6 & -1.8 & -1.3 & -0.5 & -0.3 & -2.4 & -3.5 & 0.0 & -0.2 & -0.3 & -4.4 & -2.6 & -1.0 & -3.2 & -2.3 \\
\hline FR-LBr & -7.9 & -3.0 & -0.5 & -1.4 & -1.8 & -3.2 & -1.9 & -1.2 & -0.3 & -0.3 & -3.1 & -3.0 & 0.0 & -0.4 & -0.7 & -5.9 & -2.1 & -1.0 & -2.7 & -2.6 \\
\hline FR-Pue & -2.7 & -2.3 & -0.5 & -1.1 & -1.2 & -0.6 & -0.9 & -0.6 & -0.3 & -0.1 & -0.9 & -2.3 & 0.0 & -0.3 & -0.5 & -1.8 & -1.6 & -0.6 & -1.5 & -1.1 \\
\hline IT-Col & -2.8 & -1.4 & -0.5 & -1.2 & -1.0 & -0.8 & -0.6 & -0.7 & -0.3 & -0.1 & -1.1 & -1.2 & 0.0 & -0.4 & -0.6 & -2.0 & -1.0 & -0.5 & -2.9 & -1.9 \\
\hline IT-Ren & -2.2 & -1.2 & -0.3 & -1.3 & -1.0 & -0.8 & -0.7 & -0.9 & -0.3 & -0.2 & -1.0 & -0.9 & 0.0 & -0.5 & -0.5 & -1.6 & -0.8 & -1.0 & -2.4 & -1.4 \\
\hline IT-Ro2 & -12.3 & -2.5 & -0.5 & -2.0 & -1.8 & -2.9 & -1.0 & -0.5 & -0.5 & -0.2 & -4.4 & -2.5 & 0.0 & -0.7 & -0.9 & -6.8 & -1.7 & -0.7 & -3.7 & -2.4 \\
\hline IT-SRo & -5.6 & -3.2 & -0.6 & -2.1 & -2.2 & -1.8 & -1.9 & -1.0 & -0.5 & -0.3 & -2.2 & -3.2 & 0.0 & -0.6 & -1.0 & -4.0 & -2.2 & -1.0 & -3.8 & -3.0 \\
\hline NL-Loo & -25.7 & -3.6 & -3.1 & -5.1 & -4.1 & -11.5 & -2.4 & -9.4 & -1.2 & -0.7 & -11.1 & -3.5 & -2.3 & -1.2 & -1.5 & -20.6 & -2.4 & -7.6 & -8.0 & -4.6 \\
\hline NL-Spe & -28.4 & -4.6 & -1.5 & -4.4 & -5.0 & -9.9 & -2.6 & -5.2 & -1.0 & -0.6 & -10.0 & -4.5 & -1.7 & -1.0 & -1.7 & -19.2 & -3.1 & -4.3 & -5.7 & -4.7 \\
\hline PT-Esp & -6.9 & -1.9 & -1.2 & -1.3 & -1.3 & -1.2 & -0.5 & -1.0 & -0.3 & -0.2 & -2.3 & -1.9 & -0.1 & -0.3 & -0.4 & -2.8 & -1.5 & -1.8 & -1.0 & -0.7 \\
\hline PT-Mi1 & -5.2 & -2.0 & -0.4 & -1.3 & -1.2 & -1.5 & -0.8 & -0.5 & -0.3 & -0.2 & -2.1 & -2.2 & 0.0 & -0.4 & -0.5 & -3.0 & -1.6 & -0.6 & -2.0 & -1.2 \\
\hline RU-Fyo & -2.2 & -2.0 & -0.2 & -1.4 & -0.7 & -0.8 & -1.2 & -0.6 & -0.3 & -0.1 & -1.2 & -1.3 & 0.0 & -0.3 & -0.3 & -2.3 & -1.2 & -0.4 & -2.7 & -1.0 \\
\hline SE-Nor & -2.1 & -0.9 & -0.3 & -0.8 & -0.5 & -0.9 & -0.6 & -0.8 & -0.2 & -0.1 & -0.9 & -0.7 & 0.0 & -0.2 & -0.2 & -1.5 & -0.6 & -0.6 & -1.2 & -0.6 \\
\hline SE-Sk2 & -1.5 & -1.1 & -0.2 & -0.7 & -0.5 & -0.5 & -0.7 & -0.7 & -0.2 & -0.1 & -0.7 & -0.9 & 0.0 & -0.1 & -0.2 & -1.0 & -0.8 & -0.6 & -1.2 & -0.7 \\
\hline UK-Gri & -2.1 & -1.6 & -0.2 & -1.0 & -1.3 & -0.7 & -0.9 & -0.4 & -0.2 & -0.2 & -1.0 & -1.5 & 0.0 & -0.2 & -0.5 & -2.2 & -0.9 & -0.4 & -2.1 & -2.1 \\
\hline DE-Meh & -5.6 & -1.3 & -0.8 & -0.4 & -0.3 & -2.6 & -1.2 & -2.5 & -0.5 & -0 & -2.4 & -1.3 & -0.1 & -0.4 & -0.5 & -5.6 & -1.1 & -2.1 & -0.6 & -0.3 \\
\hline ES-VDA & -1.9 & -0.3 & -0.2 & -0.2 & -0.1 & -0.7 & -0.3 & -0.5 & -0.2 & -0.1 & -0.9 & -0.3 & 0.0 & -0.2 & -0.2 & -2.0 & -0.3 & -0.5 & -0.4 & -0.2 \\
\hline FI-Lom & -0.3 & -0.1 & 0.0 & -0.1 & 0.0 & -0.1 & -0.1 & 0.0 & -0.1 & 0.0 & -0.1 & -0.1 & 0.0 & 0.0 & 0.0 & -0.1 & -0.1 & 0.0 & -0.1 & 0.0 \\
\hline HU-Bug & -5.8 & -0.9 & -0.5 & -0.3 & -0.2 & -2.1 & -0.7 & -1.1 & -0.4 & -0.1 & -2.6 & -0.9 & -0.1 & -0.3 & -0.2 & -5.7 & -0.8 & -1.3 & -0.7 & -0.2 \\
\hline IT-Amp & -1.1 & -0.3 & -0.4 & -0.1 & & -0 & -0.2 & -0.4 & -0.1 & 0.0 & -0.5 & -0.3 & 0.0 & -0.2 & -0 & -1.1 & -0.3 & -0.8 & -0.5 & -0.2 \\
\hline IT-MBo & -2.1 & -0.6 & -0.4 & -0.1 & -0.1 & -0.7 & -0.5 & -0.7 & -0.2 & -0.1 & -1.1 & -0.6 & 0.0 & -0.3 & -0.3 & -2.4 & -0.5 & -1.1 & -0.6 & -0.4 \\
\hline NL-Hor & -13.9 & -2.6 & -3.7 & -0.7 & -0.7 & -6.0 & -2.2 & -9.7 & -0.8 & -0.5 & -8.0 & -2.6 & -1.7 & -0.6 & -1.0 & -16.9 & -2.0 & -10.1 & -1.2 & -0.9 \\
\hline PL-wet & -4.5 & -1.2 & -0.4 & -0.4 & -0.2 & -1.4 & -0.8 & -0.9 & -0.5 & -0.2 & -2.1 & -1.1 & 0.0 & -0.4 & -0.3 & -4.0 & -1.0 & -1.2 & -0.9 & -0.4 \\
\hline UK-AMo & -2.9 & -0.6 & -0.5 & -0.2 & -0.2 & -1.2 & -0.5 & -1.1 & -0.2 & -0.1 & -1.5 & -0.5 & 0.0 & -0.1 & -0.2 & -3.2 & -0.4 & -1.1 & -0.2 & -0.1 \\
\hline $\mathrm{CH}-\mathrm{Oel}$ & 0.1 & -1.0 & -3.8 & -0.2 & -0.2 & -1.4 & -0.9 & -5.9 & -0.3 & -0.2 & -1.9 & -1.0 & -2.7 & -0.2 & -0.3 & -3.2 & -0.9 & -6.6 & -0.8 & -0.5 \\
\hline DE-Gri & 5.6 & -1.1 & -1.1 & -0.2 & -0.2 & -0.9 & -1.0 & -2.0 & -0.2 & -0.1 & -1.3 & -1.1 & -0.2 & -0.2 & -0.2 & -1.8 & -1.0 & -1.8 & -0.4 & -0.2 \\
\hline DK-Lva & 1.9 & -0.9 & -1.0 & -0.2 & -0.5 & -2.1 & -0.8 & -2.2 & -0.2 & -0.3 & -2.1 & -0.9 & 0.0 & -0.2 & -0.4 & -4.5 & -0.8 & -2.0 & -0.3 & -0.2 \\
\hline FR-Lq2 & -0.2 & -0.7 & -0.2 & -0.2 & -0.2 & -1.3 & -0.6 & -0.6 & -0.2 & -0.1 & -1.5 & -0.6 & 0.0 & -0.1 & -0.2 & -2.9 & -0.6 & -0.4 & -0.2 & -0.1 \\
\hline IE-Ca2 & 1.3 & -0.4 & -0.3 & -0.2 & -0.1 & -1.8 & -0.3 & -0.6 & -0.2 & -0.1 & -1.8 & -0.4 & 0.0 & -0.1 & -0.2 & -4.3 & -0.3 & -0.5 & -0.3 & -0.2 \\
\hline IE-Dri & -2.2 & -0.4 & -0.2 & -0.2 & -0.2 & -3.5 & -0.4 & -0.5 & -0.2 & -0.1 & -3.8 & -0.4 & 0.0 & -0.2 & -0.3 & -9.3 & -0.4 & -0.4 & -0.3 & -0.1 \\
\hline NL-Ca1 & -5.8 & -1.6 & -4.0 & -0.6 & -0.6 & -9.5 & -1.5 & -8.3 & -0.6 & -0.4 & -9.8 & -1.6 & -2.2 & -0.4 & -0.6 & -19.1 & -1.4 & -7.0 & -0.7 & -0.5 \\
\hline UK-EBu & -0.2 & -0.5 & -0.3 & -0.1 & -0.1 & -1.2 & -0.5 & -0.7 & -0.2 & -0.1 & -1.1 & -0.5 & 0.0 & -0.1 & -0.2 & -2.6 & -0.4 & -0.6 & -0.2 & -0.1 \\
\hline BE-Lon & 0.5 & -1.1 & -1.4 & -0.7 & -0.6 & -3.0 & -0.9 & -3.6 & -0.4 & -0.3 & -3.1 & -1.1 & -0.4 & -0.2 & -0.1 & -6.1 & -0.9 & -3.0 & -0.7 & -0.4 \\
\hline DE-Geb & 1.5 & -0.9 & -0.9 & -0.8 & -0.4 & -2.5 & -0.7 & -1.9 & -0.5 & -0.2 & -2.2 & -0.9 & -0.1 & -0.2 & -0.1 & -5.5 & -0.7 & -1.8 & -0.8 & -0.3 \\
\hline DE-Kli & 1.9 & -1.2 & -0.9 & -0.8 & -0.5 & -1.7 & -1.0 & -2.4 & -0.4 & -0.2 & -2.0 & -1.2 & -0.1 & -0.2 & -0.1 & -3.6 & -1.0 & -1.9 & -0.6 & -0.3 \\
\hline DK-Ris & -1.9 & -0.3 & -0.7 & -0.3 & -0.3 & -3.7 & -0.3 & -1.6 & -0.2 & -0.1 & -4.1 & -0.3 & 0.0 & -0.2 & -0.1 & -6.7 & -0.3 & -1.5 & -0.7 & -0.3 \\
\hline FR-Gri & 1.0 & -1.5 & -0.8 & -0.6 & -0.6 & -2.9 & -1.2 & -2.8 & -0.3 & -0.3 & -2.9 & -1.5 & -0.6 & -0.1 & -0.2 & -6.2 & -1.3 & -2.0 & -0.4 & -0.4 \\
\hline IT-BCi & 1.6 & -1.8 & -0.5 & -2.3 & -0.7 & -6.2 & -1.3 & -1.1 & -1.3 & -0.3 & -5.7 & -1.8 & 0.0 & -0.5 & -0.2 & -16.3 & -1.5 & -1.1 & -2.0 & -0.4 \\
\hline IT-Cas & 4.1 & -0.8 & -0.6 & -0.5 & -0.4 & -1.9 & -0.6 & -0.6 & -0.3 & -0.3 & -2.1 & -0.8 & 0.0 & -0.5 & -0.4 & -3.9 & -0.7 & -1.0 & -2.9 & -1.8 \\
\hline UA-Pet & -0.2 & -0.8 & -0.2 & -0.7 & -0.3 & -1.4 & -0.6 & -0.6 & -0.4 & -0.1 & -1.9 & -0.7 & 0.0 & -0.4 & -0.1 & -2.9 & -0.7 & -0.5 & -1.4 & -0.4 \\
\hline UK-ESa & na & na & na & na & na & na & na & na & na & na & na & na & na & na & na & na & na & na & na & na \\
\hline
\end{tabular}

* "na": not available.

the CBED model (Fig. A3 of Supplement). A full sensitivity analysis of the models is beyond the scope of this paper, but these results show that models have different sensitivities to input data and that the various land use classes respond differently. These tests also demonstrate that uncertainties in inferential dry deposition estimates could be reduced by the on-site recording of vegetation parameters (LAI, $\left.h_{\mathrm{c}}\right)$. The uncertainty associated with surface potentials $(T, \mathrm{RH})$ depends on the experimental conditions for the data on which the paramerisations were originally based. For non-stomatal resistances, ambient (e.g. $2 \mathrm{~m}$ above canopy) values have often been used, though not always (e.g. Flechard et al., 2010), while for the measurement of leaf stomatal conductances, temperature is measured in situ in a leaf cuvette.

Over $\mathrm{F}$ and $\mathrm{SN}$ ecosystems, the largest $\mathrm{N}_{\mathrm{r}}$ dry deposition estimates were consistently given by CBED and IDEM, which were largely in agreement, while the EMEP-03 and CDRY fluxes were typically a factor of 2 smaller. The largest annual $\mathrm{N}_{\mathrm{r}}$ dry deposition to forests was derived for The Netherlands (NL-Loo, NL-Spe) and Belgium (BE-Bra), 


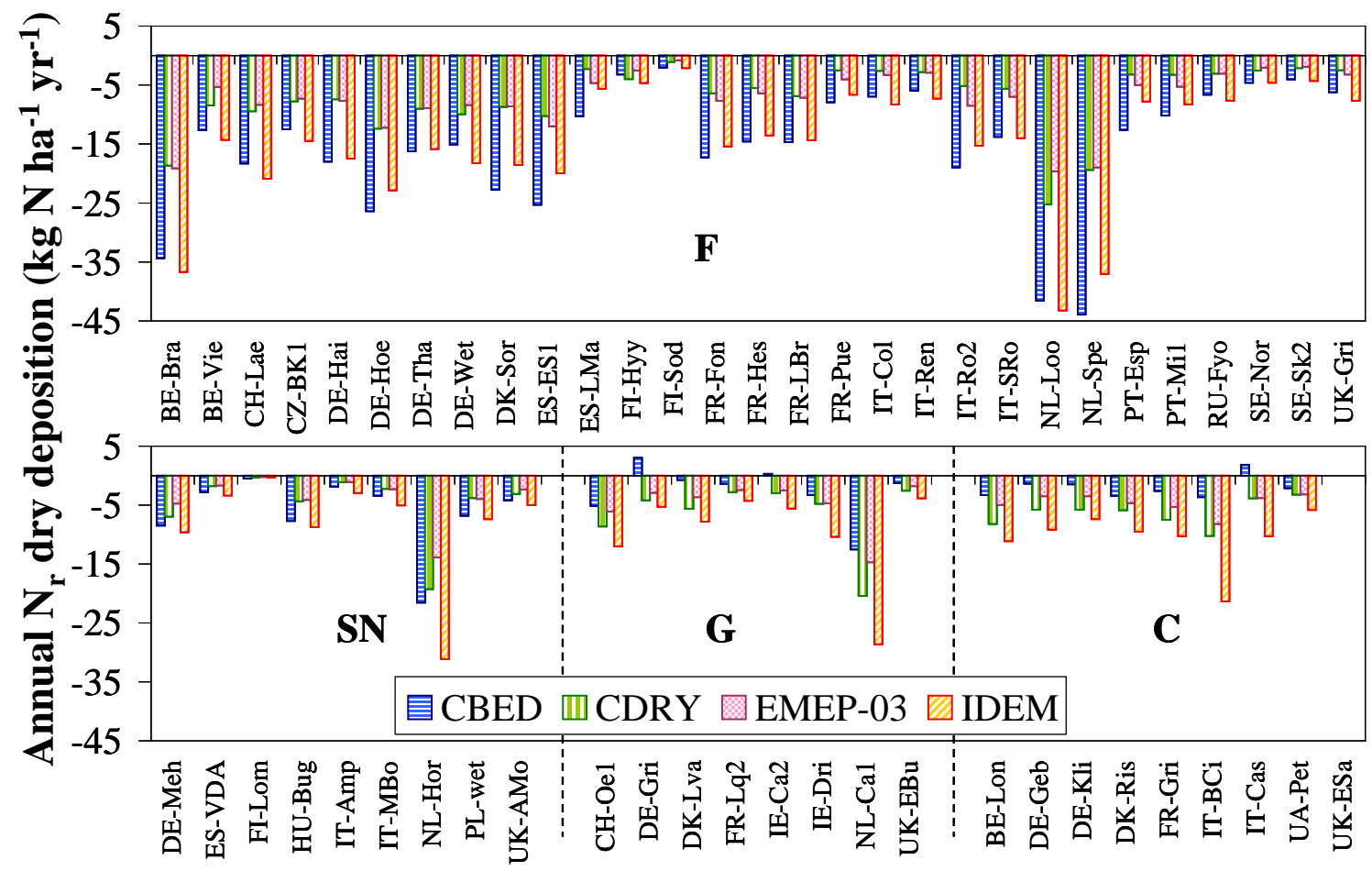

Fig. 4. Modelled annual $\mathrm{N}_{\mathrm{r}}$ dry deposition to $\mathrm{NEU}$ monitoring sites. Data are calculated as the sum of $\mathrm{NH}_{3}, \mathrm{HNO}_{3}$, aerosol $\mathrm{NH}_{4}^{+}$and $\mathrm{NO}_{3}^{-}$ fluxes from DELTA measurements, plus $\mathrm{NO}_{2}$ dry deposition from modelled (EMEP $50 \times 50 \mathrm{~km}$ ) or measured $\mathrm{NO}_{2}$ concentrations.

while remote boreal forests (FI-Hyy, FI-Sod, SE-Nor) received the smallest inputs. Similar differences occurred in $\mathrm{SN}$ ecosytems, with less than $1 \mathrm{~kg} \mathrm{Nha}^{-1} \mathrm{yr}^{-1}$ at FI-Lom compared with about $15-25 \mathrm{~kg} \mathrm{Nha}^{-1} \mathrm{yr}^{-1}$ at NL-Hor. Dry deposition of $\mathrm{N}_{\mathrm{r}}$ to short semi-natural vegetation was dominated by $\mathrm{NH}_{3}$, except in CDRY, contributing typically 50 $75 \%$ of total dry deposition inputs, depending on the model (Fig. 5). Despite similar concentrations overall (Table 2), the relative contribution of $\mathrm{NH}_{3}$ was less over $\mathrm{F}$ than over $\mathrm{SN}$, typically only $30-40 \%$, either because aerosol deposition rates were larger, especially in CBED and IDEM (Fig. 3), or because $\mathrm{HNO}_{3}$ fluxes were large, being of the same order as $\mathrm{NH}_{3}$ over forests in the CDRY and EMEP-03 models (Fig. 5).

Although the deposition velocity of $\mathrm{NO}_{2}$ was small compared with that of $\mathrm{NH}_{3}$ and $\mathrm{HNO}_{3}$ (Fig. 3), the comparatively large ambient $\mathrm{NO}_{2}$ concentrations at a few sites (BE-Bra, FI-Hyy, IT-Ren, NL-Spe, CH-Oe1, FR-Gri) resulted in $\mathrm{NO}_{2}$ contributing a large - and sometimes dominant - fraction of total $\mathrm{N}_{\mathrm{r}}$ dry deposition at some sites (Fig. 5), especially with CDRY. In a scoping study of 14 short-term inferential campaigns over 8 CAPMoN sites in Eastern and Central Canada, Zhang et al. (2009) estimated that the combined dry deposition of $\mathrm{NO}_{2}$, PAN and other $\mathrm{NO}_{\mathrm{y}}$ species contributed between $4 \%$ and $18 \%$ of total (dry + wet) $\mathrm{N}_{\mathrm{r}}$ deposition. In that study, $\mathrm{NO}_{2}$ contributed $35 \%$ of $\mathrm{N}_{\mathrm{r}}$ dry deposition, while
PAN + PPN contributed $6 \%, \mathrm{NO} 5 \%, \mathrm{HNO}_{3} 4 \%$, aerosol $\mathrm{NO}_{3}^{-} 6 \%$, other $\mathrm{NO}_{\mathrm{y}}$ species $11 \%$, aerosol $\mathrm{NH}_{4}^{+} 26 \%$ and $\mathrm{NH}_{3}$ just 7\% (fractions averaged across the 14 sites). Most sites of the NEU network, however, were located in remote or rural landscapes, and although $\mathrm{NO}_{2}$ concentrations were not measured everywhere, it may be assumed that $\mathrm{NO}_{2}$ generally contributed less than 10-20\% of dry $\mathrm{N}_{\mathrm{r}}$ deposition, as observed at e.g. IT-Col, FI-Lom, UK-AMo, HUBug, despite the larger $\mathrm{NO}_{2}$ share predicted by CDRY (Fig. 5). The estimated $\mathrm{NO}_{2}$ contribution was especially small, and often even nought, with the EMEP-03 routine due to the implementation of the $4 \mathrm{ppb}$ threshold (Sect. 2.1.1). HONO was generally not detectable except at roadside (e.g. CH-Oe1) and suburban sites (FR-Gri, FR-Fon), but concentrations were very small and may partly have resulted from a sampling artefact, and HONO deposition is neglected here, also given that inferential modelling of HONO is very uncertain due to the possibility of heterogeneous production at surfaces.

Over managed grassland and crops, the compensation point approach in CBED allowed a few sites to be net annual emitters of $\mathrm{NH}_{3}$ and even of $\mathrm{N}_{\mathrm{r}}$ (e.g. DE-Gri, IT-Cas) in background conditions (without accounting for fertiliser- or grazing-induced emissions), while the other models consistently predicted a net $\mathrm{N}_{\mathrm{r}}$ sink of the order of 5$15 \mathrm{~kg} \mathrm{Nha}^{-1} \mathrm{yr}^{-1}$. The two agricultural sites with the largest (monthly mean and maximum) ambient $\mathrm{NH}_{3}$ concentrations, 


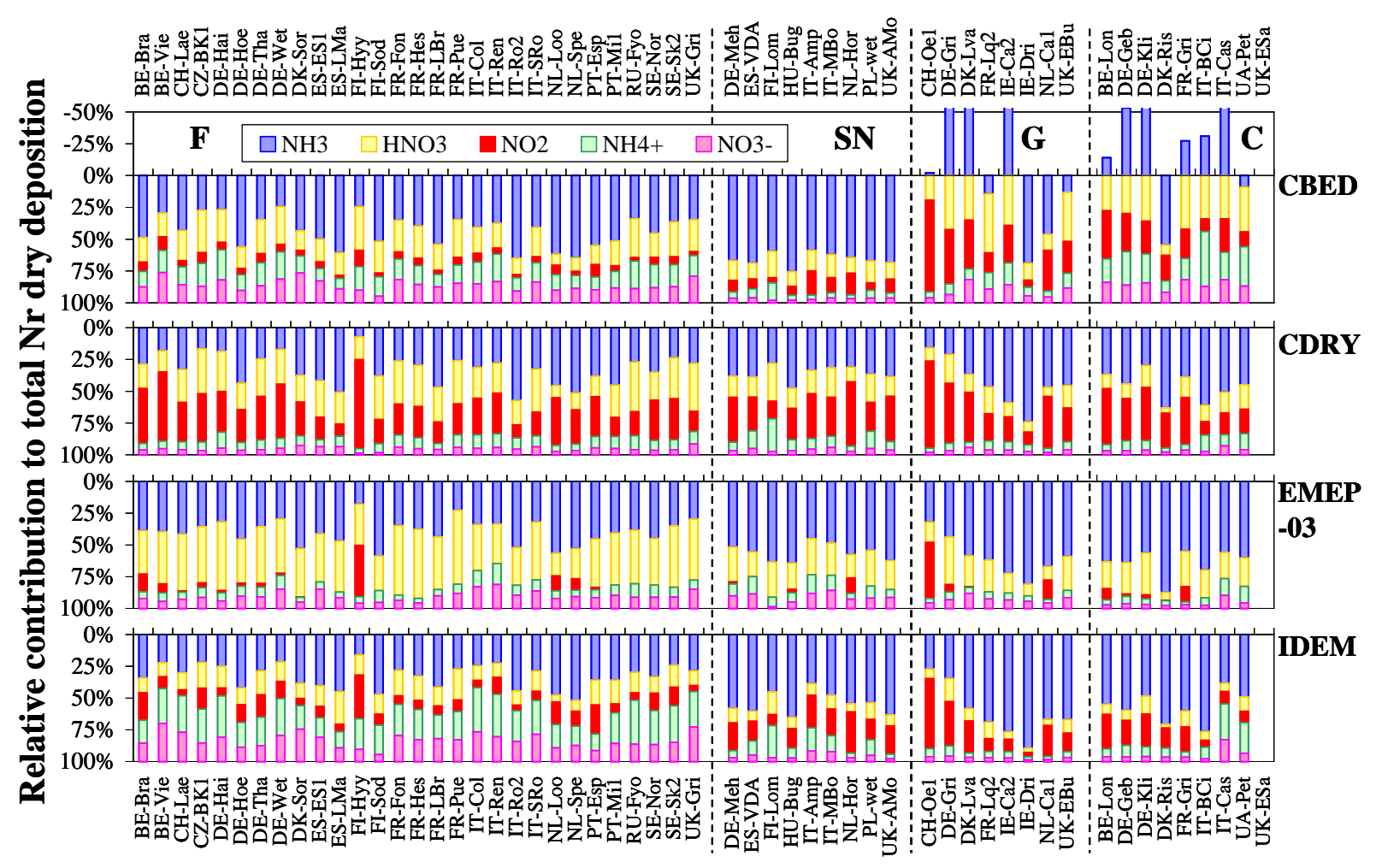

Fig. 5. Relative contributions of $\mathrm{N}_{\mathrm{r}}$ species to total inorganic $\mathrm{N}$ dry deposition. For $\mathrm{G}$ and $\mathrm{C}$ data in CBED (top panel), negative percentages for $\mathrm{NH}_{3}$ denote net $\mathrm{NH} 3$ emissions, which are expressed relative to the sum of dry deposition fluxes for the other four $\mathrm{N}_{\mathrm{r}}$ species.

at NL-Ca1 and IT-BCi (Table 2), are also the sites where modelled annual dry deposition is largest, possibly in excess of $20 \mathrm{~kg} \mathrm{Nha}^{-1} \mathrm{yr}^{-1}$. This is logical from an inferential modelling point of view, but it is quite possible that at such sites the large concentration background observed in the surface layer may result, in part, from emissions by the underlying vegetation, leaf litter and soil in crops at IT-BCi (Nemitz et al., 2000b; Bash et al., 2010), or grazing animals in the case of NL-Ca1. If this were the case, net ecosystem emission could actually prevail at these sites, even outside periods following fertilisation events. The inadequacy of $R_{\mathrm{c}}$ inferential approaches for $\mathrm{NH}_{3}$ (CDRY, EMEP-03, IDEM), or even of single layer $\left(\chi_{\mathrm{s}} / R_{\mathrm{W}}\right)$ compensation point modelling (CBED), in the case of fertilised and managed agricultural systems, has long been recognized (Sutton et al., 1993; Fowler et al., 2009). New parameterisations for $\mathrm{NH}_{3}$ in CTMs are emerging (Zhang et al., 2010; Massad et al., 2010), which seek to relate the $\mathrm{NH}_{3}$ emission potential to the plant/ecosystem $\mathrm{N}$ status, via total $\mathrm{N}$ inputs through atmospheric $\mathrm{N}$ deposition and fertilisation. For such systems the challenge does not actually reside in the determination of atmospheric $\mathrm{Nr}$ inputs in excess of fertilisation, since atmospheric deposition represent typically less than $10 \%$ of added fertiliser, but rather in the quantification of field $\mathrm{NH}_{3}$ emissions and their contribution to regional atmospheric $\mathrm{N}_{\mathrm{r}}$ budgets (Flechard et al., 2010).
It should be noted that concentration levels of organic $\mathrm{N}_{\mathrm{r}}$ compounds, which were not considered in the present study, can be significant in the troposphere, although their sources, sinks and concentrations are not well known. Water-soluble organic N (WSON) contributed typically $20-25 \%$ of total gas and particulate $\mathrm{N}_{\mathrm{r}}$ in rural air in Scotland (González Benítez et al., 2010), but WSON speciation and deposition velocities remain uncertain. Published dry deposition measurements of PAN point to $V_{\mathrm{d}}$ values of the order of 1$2 \mathrm{~mm} \mathrm{~s}^{-1}$ over grass (Doskey et al., 2004), and up to 10 $15 \mathrm{~mm} \mathrm{~s}^{-1}$ over coniferous forest in daytime, equivalent to a canopy resistance of the order of $100 \mathrm{~s} \mathrm{~m}^{-1}$ (Turnipseed et al., 2006; Wolfe et al., 2009), suggesting that PAN deposition to forests may be much faster than predicted by current algorithms (e.g. Zhang et al., 2009). With typical PAN concentrations of $0.1-1 \mathrm{ppb}$, Turnipseed et al. (2006) calculated that PAN contributed about $20 \%$ of daytime, summertime $\mathrm{NO}_{\mathrm{y}}\left(\mathrm{NO}+\mathrm{NO}_{2}+\mathrm{HNO}_{3}+\mathrm{NO}_{3}^{-}+\mathrm{PAN}\right)$ dry deposition at their forest site. However, considering the strong control of PAN deposition by stomatal opening and uptake (Doskey et al., 2004), and the consequently reduced $V_{\mathrm{d}}$ at night and in winter, the contribution of PAN and other known atmospheric organic nitrates to total $\mathrm{N}_{\mathrm{r}}$ inputs must be minor on the annual time scale. 


\subsection{Comparison with micrometeorological flux monitoring datasets within the NITROEUROPE network}

The surface/atmosphere exchange of reactive nitrogen has been investigated and measured at numerous sites in Europe and elsewhere, yet this has been done most often campaignwise, with measurements lasting typically a few days to a few weeks. The data thus obtained are invaluable for understanding exchange processes and developing parameterisations for atmospheric models, but they typically cover only a limited range of meteorological conditions, atmospheric concentrations and vegetation development stages. The validation of inferential models at the ecosystem scale benefits much from comparisons with long-term flux measurement datasets, as the wide range of environmental conditions covered is useful for highlighting deficiencies in process understanding and for comparing scaled-up, annual estimates with actual, measured dry deposition. In general, such long-term micrometeorological flux datasets are rare in the case of $\mathrm{NH}_{3}$ and $\mathrm{NO}_{\mathrm{x}}$, and almost non-existent for $\mathrm{HNO}_{3}$ and aerosol $\mathrm{NH}_{4}^{+}$and $\mathrm{NO}_{3}^{-}$. For the sites considered in this study, there are long-term data for $\mathrm{NH}_{3}$ and $\mathrm{NO}_{\mathrm{x}}$ only, at 5 and 3 sites, respectively, which are discussed in Sects. 3.3.1 and 3.3.2; there are no available long-term datasets of $\mathrm{HNO}_{3}$ and aerosol fluxes. Aerosol deposition has been measured at NL-Spe (summarised in Ruijgrok et al., 1997) and UK-Amo (Nemitz et al., 2002), but annual fluxes were not estimated, the focus being on the understanding of variations in deposition velocity.

In the few cases when long-term $\mathrm{Nr}$ flux estimates are available, the flux data capture is generally much lower than $100 \%$ and typically closer to $50 \%$ over one year; this means that measurement-based annual estimates are a combination of measurements and gap-filling and cannot be treated as absolutely accurate reference values, and are subject to some uncertainty. The procedures typically used in the annual datasets presented hereafter involved either the calculation of mean monthly diurnal cycles of measured fluxes, ensuring that season and time of day are properly weighted and accounted for; or the filling of gaps in the flux time series using inferential models with parameters fitted to local conditions (e.g. Flechard et al., 2010), or using neural networks (Neyrinck et al., 2007).

It should also be noted here that many forest sites of the NEU network have been monitoring wet-only or bulk deposition and throughfall as part of national or international initiatives (e.g. the ICPForests programme of the CLRTAP; http://www.icp-forests.org/), which, by difference between above- and below-canopy fluxes, have been used to provide estimates of dry deposition. However, uncertainties are large due to canopy interactions (Lovett and Lindberg, 1993; Zimmermann et al., 2006; Neirynck et al., 2007; Simpson et al., 2006b) and such data cannot be used reliably for model validation.

\subsection{1 $\mathrm{NH}_{3}$}

Only two forest sites (BE-Bra, NL-Spe) within the NEU network have actually monitored annual $\mathrm{NH}_{3}$ dry deposition in the past using the flux-gradient technique (Fig. 6). The measurements by Neirynck et al. (2007) at BE-Bra suggested an annual deposition input of nearly $-20 \mathrm{~kg} \mathrm{~N} \mathrm{ha}^{-1} \mathrm{yr}^{-1}$, which is larger than the output of any of the four models in the present study (Table 3), whose ensemble average is only of the order of $-10 \mathrm{~kg} \mathrm{Nha}^{-1} \mathrm{yr}^{-1}$ (Fig. 6). Only part of the difference may be explained by the larger mean $\mathrm{NH}_{3}$ concentration $\left(3.0 \mathrm{\mu g} \mathrm{m}^{-3}\right)$ at the time of the flux measurements in 1999-2001 (Neirynck et al., 2007) than in the NEU DELTA dataset $\left(2.3 \mathrm{\mu g} \mathrm{m}^{-3}\right)$ in 2007-2008. A clear indication that especially CDRY and EMEP-03 both largely underestimated $\mathrm{NH}_{\mathrm{X}}\left(\mathrm{NH}_{3}+\mathrm{NH}_{4}^{+}\right)$dry deposition at BE-Bra, with annual fluxes of the order of -6 to $-8 \mathrm{~kg} \mathrm{Nha}^{-1} \mathrm{yr}^{-1}$ (Table 3 ), is provided by a comparison with throughfall data. Measured wet deposition of $\mathrm{NH}_{\mathrm{X}}$ was $7 \mathrm{~kg} \mathrm{Nha}^{-1} \mathrm{yr}^{-1}$ at BE-Bra, which together with dry deposition from CDRY or EMEP-03, would total around $15 \mathrm{~kg} \mathrm{NH}_{\mathrm{X}}-\mathrm{Nha}^{-1} \mathrm{yr}^{-1}$, while the measured throughfall was actually $18 \mathrm{~kg} \mathrm{NH}_{\mathrm{X}^{-}}$ $\mathrm{N} \mathrm{ha}^{-1} \mathrm{yr}^{-1}$ over the same time period (J. Neirynck, personal communication, 2011).

The comparison is more favourable at NL-Spe, where the measured dry deposition in 1995 of $-17.9 \mathrm{~kg} \mathrm{NH}_{3^{-}}$ $\mathrm{Nha}^{-1} \mathrm{yr}^{-1}$ (Erisman et al., 1996) is well in the range of the four model estimates in the NEU dataset and close to the ensemble mean $\left(-16.9 \mathrm{~kg} \mathrm{NH}_{3}-\mathrm{N} \mathrm{ha}^{-1} \mathrm{yr}^{-1}\right)$ (Fig. 6), with the difference in mean concentrations between the two periods being consistent with the model/measurement difference. A striking element in the comparison of BE-Bra with NL-Spe is the roughly equal measured annual $\mathrm{NH}_{3}$ dry deposition at the two sites $\left(-19.6\right.$ vs. $\left.-17.9 \mathrm{~kg} \mathrm{NH}_{3}-\mathrm{N} \mathrm{ha}^{-1} \mathrm{yr}^{-1}\right)$ while the mean concentration was about $50 \%$ larger at NL-Spe, pointing to a much smaller $R_{\mathrm{c}}$ at BE-Bra, since the annual mean $u_{*}$ was identical $\left(0.51 \mathrm{~m} \mathrm{~s}^{-1}\right)$ at the two sites. The much smaller mean $\mathrm{NH}_{3} / \mathrm{SO}_{2}$ molar ratio at BE-Bra (2.9) than at NL-Spe (11.1) has been held responsible for the difference in measured $R_{\mathrm{c}}$ for $\mathrm{NH}_{3}$ (Neirynck et al., 2005), but the effect of leaf surface chemistry on deposition rates is not adequately reflected in most dry deposition models. Flux measurements at BE-Bra during 1999-2001 showed a reduced $R_{\mathrm{c}}$ for $\mathrm{NH}_{3}$ and larger $R_{\mathrm{c}}$ for $\mathrm{SO}_{2}$ during winter when the $\mathrm{NH}_{3} / \mathrm{SO}_{2}$ molar ratio was below 1; in summer this ratio was larger than 3 and $R_{\mathrm{c}}$ for $\mathrm{SO}_{2}$ was correspondingly smaller, while $R_{\mathrm{c}}$ for $\mathrm{NH}_{3}$ was increased (J. Neyrinck, personal communication, 2011). Because in Europe the total acid concentration is not necessarily dominated by $\mathrm{SO}_{2}$, the molar ratio of $\mathrm{NH}_{3}$ to the sum of the main atmospheric strong acids $\left(\mathrm{SO}_{2}, \mathrm{HNO}_{3}, \mathrm{HCl}\right)$ is actually a better proxy for linking surface resistance to the pollution climate (Flechard et al., 1999); this ratio was almost a factor of 3 smaller at BE-Bra (1.6) than at NL-Spe (4.5), with BE-Bra being the second most acidic site of the NEU network, after CZ-BK1. 


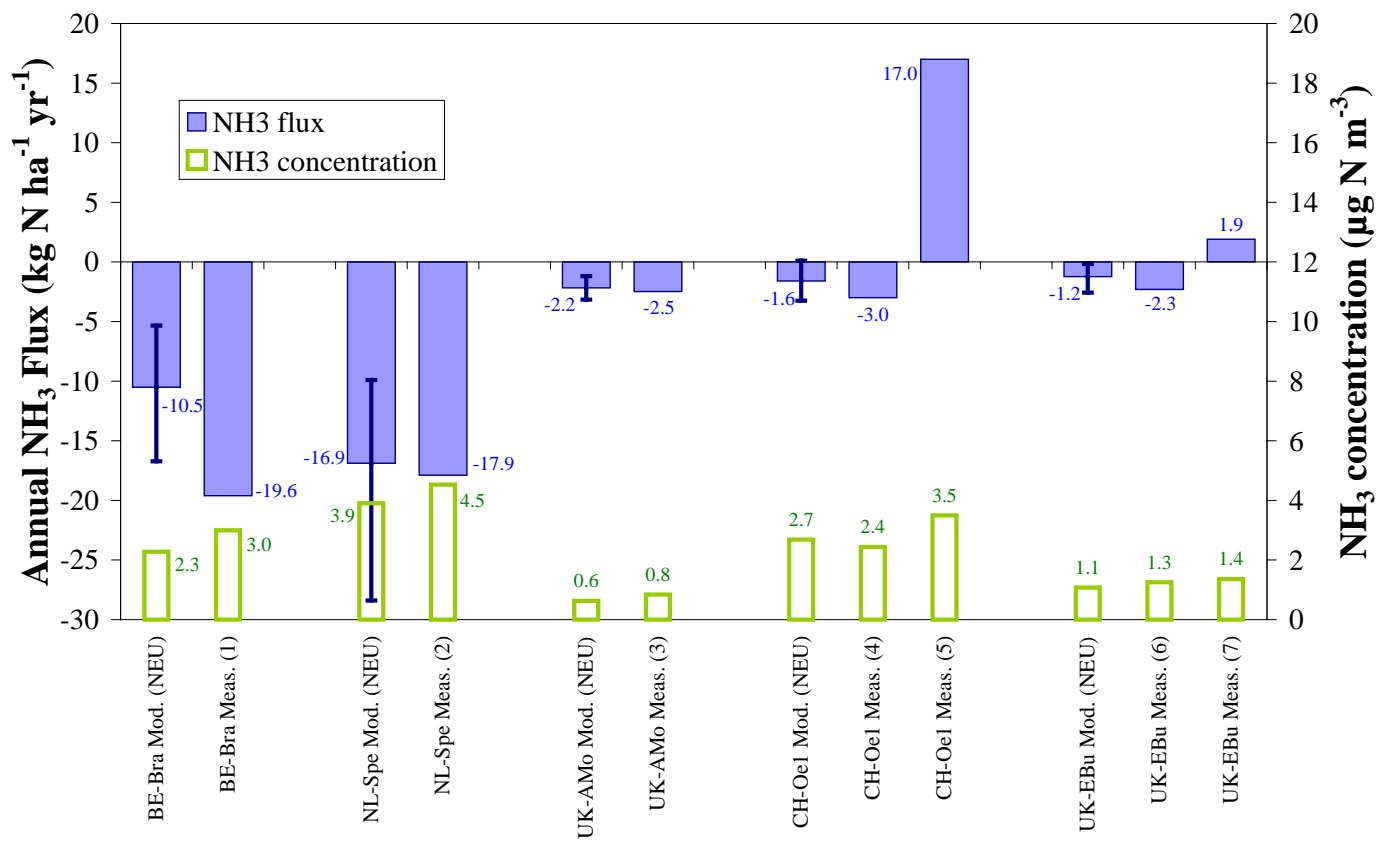

Fig. 6. Comparison of modelled annual $\mathrm{NH}_{3}$ exchange from NEU network DELTA data with measured estimates from historical long-term micrometeorological flux datasets. For five monitoring sites, the ensemble average of CBED, CDRY, EMEP-03 and IDEM is shown with error bars showing the range (min, max) of model estimates. (1): Neirynck et al., 2007; (2): Erisman et al. (1996); (3): Flechard (1998); (4) and (5): data from Flechard et al. (2010), showing (4) the annual $\mathrm{NH}_{3}$ flux for background conditions (outside fertilisation events) and (5) the net emission flux from the whole dataset; (6) and (7): data from Milford (2004), with (6) the annual dry deposition, calculated from the net overall flux (7) minus the gross annual emission of $4.2 \mathrm{~kg} \mathrm{~N} \mathrm{ha}^{-1} \mathrm{yr}^{-1}$ due to grassland management activities (fertilisation, cuts). The secondary axis shows the mean concentrations during the NEU reference period (2007-2008) as well as during the flux monitoring periods.

At the only NEU semi-natural site with a long-term $\mathrm{NH}_{3}$ flux dataset (UK-AMo) (Flechard, 1998), measured annual dry deposition in $1995\left(-2.5 \mathrm{~kg} \mathrm{Nha}^{-1} \mathrm{yr}^{-1}\right)$ is compatible with the range of model estimates in NEU for the 20072008 reference period and within $10 \%$ of the models ensemble mean $\left(-2.2 \mathrm{~kg} \mathrm{Nha}^{-1} \mathrm{yr}^{-1}\right)$. For agricultural systems in the NEU network, comparisons can only be made at the managed grasslands $\mathrm{CH}-\mathrm{Oe} 1$ and UK-EBu. For these fertilised, cut and/or grazed systems, a comparison of measurements with inferential models is only meaningful in conditions of background $\mathrm{NH}_{3}$ exchange, i.e. discarding measured $\mathrm{NH}_{3}$ emission fluxes that follow the application of manure, slurry or mineral fertilisers, as these processes are not currently considered nor implemented in inferential routines. At $\mathrm{CH}-\mathrm{Oe} 1$, the overall net measured $\mathrm{NH}_{3}$ budget was $+17 \mathrm{~kg} \mathrm{Nha}^{-1} \mathrm{yr}^{-1}$ and driven by a gross annual $\mathrm{NH}_{3}$ emission by applied cattle slurry of $+20 \mathrm{~kg} \mathrm{Nha}^{-1} \mathrm{yr}^{-1}$, but during most of the year background exchange amounted to a deposition of $-3 \mathrm{~kg} \mathrm{Nha}^{-1} \mathrm{yr}^{-1}$ (Flechard et al., 2010), which is in the range of model predictions within NEU of -3.2 to $+0.1 \mathrm{~kg} \mathrm{~N} \mathrm{ha}^{-1} \mathrm{yr}^{-1}$ (Table 3). Equally, at UK-EBu, the overall annual measured $\mathrm{NH}_{3}$ flux was a net emission of $+1.9 \mathrm{~kg} \mathrm{~N} \mathrm{ha}^{-1} \mathrm{yr}^{-1}$ but, discarding the gross $\mathrm{NH}_{3}$ emissions of $+4.2 \mathrm{~kg} \mathrm{Nha}^{-1} \mathrm{yr}^{-1}$ mostly due to mineral fertiliser and urea applications (Milford et al., 2004), one may calculate a background annual dry deposition of $-2.3 \mathrm{~kg} \mathrm{Nha}^{-1} \mathrm{yr}^{-1}$, also within the range of the four model estimates based on NEU 2007-2008 data ( -2.6 to $-0.2 \mathrm{~kg} \mathrm{Nha}^{-1} \mathrm{yr}^{-1}$, Table 3).

\subsection{2 $\mathrm{NO}_{\mathrm{x}}$}

The only available annual $\mathrm{NO}_{\mathrm{x}}$ budget estimates based on long-term flux measurements are those at BE-Bra, NL-Spe and UK-Amo; $\mathrm{NO}_{\mathrm{x}}$ flux monitoring was also carried out at a number of other sites within the NEU project (e.g. CH-Oe1, FR-Gri, HU-Bug) but the results were still being analysed and unavailable at the time of writing.

The results for BE-Bra, NL-Spe and UK-Amo are summarised in Table 4. At UK-Amo, $\mathrm{NO}_{\mathrm{x}}$ flux monitoring has shown that $\mathrm{NO}_{2}$ dry deposition fluxes were small, in the range -1 to $-5 \mathrm{ng} \mathrm{NO}_{\mathrm{x}}-\mathrm{Nm}^{-2} \mathrm{~s}^{-1}$, but also that the exchange was bi-directional with small $\mathrm{NO}_{2}$ emissions in summer daytime (Fowler et al., 1998). This results from NO emission by the underlying soil, with the oxidation by $\mathrm{O}_{3}$ to $\mathrm{NO}_{2}$ generating an effective compensation point for $\mathrm{NO}_{2}$ deposition; at low ambient $\mathrm{NO}_{2}$ concentrations, the ecosystem is a net source of $\mathrm{NO}_{\mathrm{x}}$ to the atmosphere (Pilegaard et al., 2001). In reality, it is at the soil level that a true compensation point exists for NO, which is driven by 
Table 4. Annual $\mathrm{NO}_{\mathrm{x}}$ exchange based on flux measurements at three $\mathrm{NEU}$ sites, and comparison with model results for $\mathrm{NO}_{2}$.

\begin{tabular}{|c|c|c|c|}
\hline \multirow[b]{2}{*}{ Site } & \multicolumn{2}{|c|}{$\begin{array}{l}\text { Measurement-based annual } \mathrm{NO}_{\mathrm{x}} \text { flux } \\
\qquad\left(\mathrm{kg} \mathrm{Nha}^{-1} \mathrm{yr}^{-1}\right)\end{array}$} & \multirow{2}{*}{$\begin{array}{l}\text { Modelled annual } \mathrm{NO}_{2} \text { dry deposition } \\
\qquad\left(\mathrm{kg} \mathrm{N} \mathrm{ha}^{-1} \mathrm{yr}^{-1}\right)\end{array}$} \\
\hline & $\begin{array}{l}\text { Above-canopy } \mathrm{NO}_{\mathrm{x}} \text { flux } \\
\text { (measurement years) }\end{array}$ & $\begin{array}{l}\text { Soil NO emission } \\
\text { (measurement years) }\end{array}$ & \\
\hline BE-Bra & $+2.5(1999-2001)^{2}$ & Not measured & $-5.3(-2.5$ to -8.0$)$ \\
\hline NL-Spe & $-2.8(1995)^{3}$ & $\begin{array}{l}+2.92(2009)^{4} \\
+3.46(2008)^{4} \\
+6.6(2002-2003)^{5} \\
+8.4(1993)^{6}\end{array}$ & $-3.2(-1.5$ to -5.2$)$ \\
\hline UK-Amo & $-0.6(1995)^{3}$ & Not measured & $-0.7(0$ to -1.1$)$ \\
\hline
\end{tabular}

${ }^{1}$ This study.

${ }^{2}$ Neyrinck et al. (2007).

${ }^{3}$ Erisman et al. (1996)

${ }^{4}$ A. Frumau, personal communication (2011).

${ }^{5}$ Pilegaard et al. (2006).

${ }^{6}$ Dorsey et al. (2004); flux scaled up from only 3 days' measurements.

microbial nitrification processes close to the surface. Given the oligotrophic ecosystem and wet to water-logged peaty soil at UK-Amo, however, the soil NO emission potential is very low, so that the net annual $\mathrm{NO}_{\mathrm{x}}$ flux is downward and largely dominated by $\mathrm{NO}_{2}$ stomatal uptake. Bearing this in mind, the measurement-based $\mathrm{NO}_{\mathrm{x}}$ dry deposition estimate of $-0.6 \mathrm{~kg} \mathrm{NO}_{\mathrm{x}}-\mathrm{Nha}^{-1} \mathrm{yr}^{-1}$ is comparable with the model ensemble average of $-0.7 \mathrm{~kg} \mathrm{NO}_{2}-\mathrm{N} \mathrm{ha}^{-1} \mathrm{yr}^{-1}$ (Table 4).

By contrast, the annual measurement-based $\mathrm{NO}_{\mathrm{x}}$ budget for BE-Bra (above the forest canopy) is a net emission of $+2.5 \mathrm{~kg} \mathrm{NO}_{\mathrm{x}}-\mathrm{Nha}^{-1} \mathrm{yr}^{-1}$. This has been interpreted as the result of large NO emissions by the forest floor in this nitrogen-saturated Scots pine stand (Neyrinck et al., 2007), with the within-canopy oxidation by $\mathrm{O}_{3}$ of $\mathrm{NO}$ to $\mathrm{NO}_{2}$, resulting in a net apparent $\mathrm{NO}_{2}$ evolution from the stand. Downward $\mathrm{NO}_{2}$ fluxes were only observed at high ambient $\mathrm{NO}_{2}$ concentrations $\left(>10-15 \mu \mathrm{g} \mathrm{NO}_{2}-\mathrm{N} \mathrm{m}^{-3}\right)$. High soil NO emissions, non-stationarity and chemical reactions in the air column between the soil, canopy and measurement tower in polluted environments hinder the interpretation of the total $\mathrm{NO}_{\mathrm{x}}$ flux (which is a conserved quantity) into its $\mathrm{NO}$ and $\mathrm{NO}_{2}$ parts (Fowler et al., 1998); thus no reliable $\mathrm{NO}_{2}$ dry deposition estimate could be derived for BE-Bra (Neyrinck et al., 2007).

Above canopy $\mathrm{NO}_{\mathrm{x}}$ flux monitoring at NL-Spe pointed to a net annual sink of $-2.8 \mathrm{~kg} \mathrm{NO}_{\mathrm{x}}-\mathrm{Nha}^{-1} \mathrm{yr}^{-1}$ for the year 1995 (Erisman et al., 1996). While this information also does not allow a direct comparison with modelled $\mathrm{NO}_{2}$ dry deposition from our study, and is subject to substantial uncertainty associated with the use of chemiluminescence and potential interferences by other $\mathrm{NO}_{\mathrm{y}}$ species, it can be set against available soil NO emission (dynamic chambers) data, which have been obtained at NL-Spe as part of several studies over the last two decades (Table 4). Early results from 1993 yielded an annual soil NO emis-

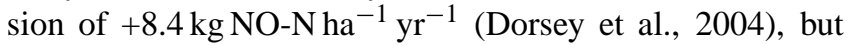
this was based on only a few days data in mid-summer. Later, as part of the NOFRETETE project and based on a more substantial dataset covering al seasons, Pilegaard et al. (2006) provided an annual estimate of $+6.6 \mathrm{~kg} \mathrm{NO}-$ $\mathrm{Nha}^{-1} \mathrm{yr}^{-1}$ for 2002-2003. Unpublished results from the NEU project itself, and thus contemporaneous with our modelling study, indicate still lower annual soil NO emissions,

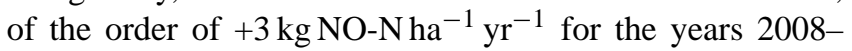
2009 (Table 4) (A. Frumau, ECN, The Netherlands, personnal communication, 2011).

The comparison of net ecosystem $\mathrm{NO}_{\mathrm{x}}$ fluxes and soil $\mathrm{NO}$ emissions can only provide a likely range for the annual $\mathrm{NO}_{2}$ deposition from the atmosphere. Dorsey et al. (2004) showed that a large fraction (around $58 \%$ on average) of the emitted NO escaped out of the trunk space to react within and above the canopy at NL-Spe, but the fraction that was actually re-captured by foliage is unknown. Assuming a mean inter-annual soil $\mathrm{NO}$ emission of the order of $+5 \mathrm{~kg} \mathrm{NO}-$ $\mathrm{N} \mathrm{ha}^{-1} \mathrm{yr}^{-1}$, the maximum possible ecosystem $\mathrm{NO}_{\mathrm{x}}-\mathrm{N}$ emission would thus be $+2.9 \mathrm{~kg} \mathrm{NO}_{\mathrm{x}}-\mathrm{Nha}^{-1} \mathrm{yr}^{-1}$, requiring a gross atmospheric $\mathrm{NO}_{2}$ dry deposition of (-2.8-2.9=)$5.7 \mathrm{~kg} \mathrm{NO}_{2}-\mathrm{N} \mathrm{ha}^{-1} \mathrm{yr}^{-1}$ to yield the observed net $\mathrm{NO}_{\mathrm{x}}$ flux (1995 data). Conversely, if all the NO emitted from soil was recycled internally in the ecosystem, then the actual $\mathrm{NO}_{2}$ deposition from the atmosphere would only be $-2.8 \mathrm{~kg} \mathrm{NO}_{2}-$ $\mathrm{N} \mathrm{ha}^{-1} \mathrm{yr}^{-1}$, which is in the range of values predicted by the inferential models. 
These data illustrate the complex nature of $\mathrm{NO}_{\mathrm{x}}$ deposition, the inability of current inferential models to deal with bi-directional exchange, and the difficulty of finding longterm $\mathrm{NO}_{2}$ deposition datasets to validate models. Net $\mathrm{NO}_{\mathrm{x}}$ deposition only occurs at $\mathrm{NO}_{2}$ concentrations in excess of the canopy compensation point; this mechanism is only included, in a rudimentary manner ( $4 \mathrm{ppb}$ threshold), in the EMEP-03 model. A mechanistic treatment of this effect in inferential models requires the knowledge of the magnitude of soil NO emissions and of within-canopy chemistry and exchange. The prediction of soil NO emissions on the basis on $\mathrm{N}$ deposition and other environmental factors (Pilegaard et al., 2006) could provide a first step in the direction of an integrated ecosystem $\mathrm{NO}_{\mathrm{x}}$ exchange approach.

\subsection{Reducing uncertainties in $\mathrm{N}_{\mathrm{r}}$ dry deposition}

The uncertainty of modelled $\mathrm{N}_{\mathrm{r}}$ dry deposition at the regional scale results from the combined uncertainties in concentrations of $\mathrm{N}_{\mathrm{r}}$ species and in their respective deposition (or exchange) velocities. Establishing a monitoring network for $\mathrm{NH}_{3}, \mathrm{HNO}_{3}, \mathrm{HONO}$ and aerosol $\mathrm{NH}_{4}^{+}$and $\mathrm{NO}_{3}^{-}$concentrations at the continental scale in Europe has been a significant step forward, even if the basic setup did not include $\mathrm{NO}_{\mathrm{x}}$ and other $\mathrm{N}_{\mathrm{r}}$ species except at a few more intensive measurement stations. Continent-scale networks of a similar size, e.g. EMEP (EMEP, 2009; Torseth et al., 2001), CASTNet (Sickles and Shadwick, 2007; Baumgardner et al., 2002) and CAPMoN (Zhang et al., 2009), have long placed the emphasis on acidifying gases $\left(\mathrm{SO}_{2}, \mathrm{HNO}_{3}, \mathrm{NO}_{\mathrm{x}}\right)$ deposition and aerosol-phase $\mathrm{N}_{\mathrm{r}}\left(\mathrm{NH}_{4}^{+}\right.$and $\left.\mathrm{NO}_{3}^{-}\right)$, but have not included the gas/particle partitioning of $\mathrm{NH}_{\mathrm{x}}$. This has been measured at selected sites as part of research projects (Erisman et al., 1996; Zimmermann et al., 2006; Neirynck et al., 2007) and has been used to evaluate the output of regional atmospheric models at selected sites (Zhang et al., 2009), but data on speciated $\mathrm{NH}_{3}$ and $\mathrm{NH}_{4}^{+}$concentrations at regional scales have been sparse and irregular outside of a few national initiatives (Bleeker et al., 2009). High time-resolution measurements with aerosol mass spectrometer measurements are also becoming available (Laj et al., 2009), although one limitation is that to date only (ultra-) fine particles can be captured: coarse nitrate is not typically measured at the same sites. The monitoring data gathered as part of NEU allow a large-scale investigation of the relative contributions of $\mathrm{NH}_{3}$ and $\mathrm{NH}_{4}^{+}$as well as $\mathrm{HNO}_{3}$ and $\mathrm{NO}_{3}^{-}$to total dry deposition, despite the large uncertainties and discrepancies associated with inferential models, and they also provide important ground validation data for CTMs.

The differences in deposition velocities between models (Fig. 3) results from both the natural variability in surface resistances found in existing $\mathrm{N}_{\mathrm{r}}$ flux datasets, leading to different parameterisations, and from the rarity and complexities of flux datasets. The physical, biological and chemical exchange mechanisms involved are too complex to model explicitly and completely from first principles, so that paramerisations tend to be empirical but dependent on few datasets, without the confidence that the statistics of large or robust numbers afford. The recent efforts by Zhang et al. (2010) and Massad et al. (2010) to bring together the existing $\mathrm{NH}_{3}$ flux and compensation point datasets into coherent and comprehensive exchange schemes for the main ecosystem types point in the right direction. Significant gaps in knowledge remain, especially with respect to surface chemistry, canopy cycling, soil/litter/vegetation interactions, management practices for agricultural systems, which will not be bridged without a more extensive coverage of $\mathrm{NH}_{3}$ fluxes. Specifically, more long-term (annual) datasets are needed for a wide variety of land uses, including broadleaf forests, crops and legume-rich grasslands, located in a wider range of pollution climates, with semi-arid and tropical regions a priority, and also in high $\mathrm{NH}_{3}$ environments, such as in the near vicinity of animal housing. Within the NitroEurope IP, intensive $\mathrm{N}_{\mathrm{r}}\left(\mathrm{NH}_{3}, \mathrm{HNO}_{3}, \mathrm{NO}_{\mathrm{x}}, \mathrm{NO}_{3}^{-}, \mathrm{NH}_{4}^{+}\right)$flux measurements to improve process understanding at a few core sites of the network have been complemented at other sites by low-cost methods for $\mathrm{N}_{\mathrm{r}}$ concentrations (DELTA) and also for fluxes (COTAG, or COnditional Time-Averaged Gradient; Famulari et al., 2010); this could serve as a blueprint for a future European $\mathrm{N}_{\mathrm{r}}$ monitoring and modelling strategy.

\section{Conclusions}

Inferential modelling with four dry deposition routines was applied to estimate annual $\mathrm{N}_{\mathrm{r}}$ fluxes at the ecosystem scale across the NitroEurope inferential network. Differences between models were reviewed in terms of canopy characteristics for the main land use types, of derived friction velocity, of stomatal conductance, and of deposition velocities and exchange rates for five dominant inorganic $\mathrm{N}_{\mathrm{r}}$ chemical species in the atmosphere $\left(\mathrm{NH}_{3}, \mathrm{HNO}_{3}, \mathrm{NO}_{2}\right.$, and aerosol $\mathrm{NH}_{4}^{+}$and $\mathrm{NO}_{3}^{-}$). Differences in stomatal conductances between models are large, but this is only decisive for $\mathrm{NO}_{2}$, which is assumed to be mainly deposited through stomata. However, these models are also routinely used for other pollutant gases such as $\mathrm{SO}_{2}$ and $\mathrm{O}_{3}$, for which the stomatal share in the total deposition is also large (see Fowler et al., 2009, and references therein). For water-soluble gases such as $\mathrm{NH}_{3}$ and $\mathrm{HNO}_{3}$, parameterisations of non-stomatal resistances are the main sources of inter-model discrepancies in deposition velocities, which can reach a factor of 3 between models for $\mathrm{NH}_{3}$. For aerosol $\mathrm{N}_{\mathrm{r}}$ deposition to forests, empirical and measurement-oriented parameterisations predict deposition rates that are a factor 5-10 larger than theoretical models. As a result, both the total modelled $\mathrm{N}_{\mathrm{r}}$ fluxes and the shares of individual $\mathrm{N}_{\mathrm{r}}$ species in the overall $\mathrm{N}_{\mathrm{r}}$ dry deposition are extremely model-dependent. The few $\mathrm{NH}_{3}$ flux datasets available for comparison within this study were within the range of models and broadly comparable with the ensemble 
average, but model validation generally suffers from a serious lack of long-term $\mathrm{N}_{\mathrm{r}}$ flux monitoring data over different vegetation types.

Inferential modelling was originally based on the concept of uni-directional exchange (deposition from the atmosphere), and has traditionally viewed vegetation elements and soil more or less as physical receptors with a given surface roughness, chemical sink strength and aerosol capture efficiency, with little regard to underlying biological and biochemical processes. The discipline is currently undergoing a paradigm shift, recognising the need to increasingly couple ecosystem modelling, including soil/litter/vegetation cycling, as well as crop/grass management and fertilisation, to surface/atmosphere bi-directional exchange frameworks, especially with respect to $\mathrm{NH}_{3}$ and $\mathrm{NO}_{\mathrm{x}}$. Here, compensation points need to be made dependent on the $\mathrm{N}$ status of the ecosystem, whether fertilised or unfertilised, characterising emission potentials that interact with advected air masses. Major developments are also needed to better deal with incanopy air chemistry and phase partitioning that affect the net exchange of $\mathrm{NH}_{3}$ and $\mathrm{HNO}_{3}$ versus $\mathrm{NH}_{4} \mathrm{NO}_{3}$ aerosol. Similarly, the roles of $\mathrm{O}_{3}$ deposition and emission of biogenic volatile organic compounds on net $\mathrm{NO}_{\mathrm{x}}$ fluxes in ecosystems need to be better understood. Although not considered in this study, uncertainties in wet deposition estimates, including the lack of WSON data, add to the total uncertainty in the $\mathrm{N}_{\mathrm{r}}$ deposition predicted by CTMs.

\section{Supplementary material related to this article is available online at: http://www.atmos-chem-phys.net/11/2703/2011/ acp-11-2703-2011-supplement.pdf.}

Acknowledgements. The authors gratefully acknowledge financial support by the European Commission (NitroEurope-IP, project 017841). Many thanks are due to all environmental chemists and scientists involved in running the DELTA network, not least N. van Dijk, I. Simmons (CEH), U. Dämmgen, J. Conrad (FAL/vTI), V. Djuricic, S. Vidic (MHSC), M. Mitosinkova (SHMU), M. J. Sanz, P. Sanz, J. V. Chorda (CEAM), M. Ferm (IVL), Y. Fauvel (INRA), T. H. Uggerud and the late J. E. Hanssen (NILU). The assistance of A. Freibauer and D. Papale in establishing this successful partnership with CarboEurope-IP and facilitating access to micrometeorological data was much appreciated, and we also thank all principal investigators, managers and operators of CarboEurope-IP sites for their individual contributions, including R. Ceulemans, J. Neirynck, M. Aubinet, C. Moureaux, N. Buchmann, W. Eugster, S. Etzold, C. Ammann, A. Neftel, C. Spirig, M. Jocher, M. V. Marek, R. Czerny, W. Kutsch, E. D. Schultze, O. Kolle, C. Bernhofer, C. Rebmann, A. Don, C. Don, S. Müller, K. Butterbach-Bahl, N. Brüggemann, L. Lotte Soerensen, K. Pilegaard, A. Ibrom, K. Larsen, P. Sørensen, H. Soegaard, A. Carrara, M. T. Sebastià, T. Vesala, T. Laurila, A. Lohila, E. Dufrêne, J. Y. Pontailler, P. Cellier, B. Loubet, S. Masson, A. Granier, B. Longdoz, P. Gross, D. Loustau, C. Lambrot, J. F. Soussana, K. Klumpp, O. Darsonville, S. Rambal, J. M. Ourcival, Z. Tuba,
L. Horvath, M. Jones, M. Saunders, F. Albanito, B. Roth, G. Kiely, P. Leahy, N. Foley, R. Valentini, G. Matteucci, P. Stefani, D. Gianelle, A. Cescatti, V. Magliulo, T. Bertolini, G. Seufert, G. Manca, A. Meijide Orive, S. Minerbi, L. Montagnani, W. Baumgartner, C. Valtingoier, E. Moors, W. C. M. van den Bulk, A. Hensen, A. Frumau, A. J. Dolman, D. Hendriks, J. Olejnik, B. H. Chojnick, G. B. A. Pita, J. S. Pereira, R. Lobo do Vale, J. Banza, A. Varlagin, A. Lindroth, M. Mölder, P. Vestin, J. Moncrieff, R. Clement, W. Medinets and S. Medinets. The meteorological data of the state forest De Inslag (Brasschaat, Belgium) have been processed from data kindly provided by the Research Institute for Nature and Forest (INBO, Belgium).

Edited by: A. S. H. Prevot

\section{References}

Andersen, H. V., Hovmand, M., Hummelshøj, P., and Jensen, N. O.: Measurements of ammonia concentrations, fluxes and dry deposition velocities to a spruce forest 1991-1995, Atmos. Environ., 33, 1367-1383, 1999.

Baldocchi, D. D., Hicks, B. B., and Camara, P.: A canopy stomatal resistance model for gaseous deposition to vegetated surfaces, Atmos. Environ., 21, 91-101, 1987.

Bash, J. O., Walker, J. T., Katul, G. G., Jones, M. R., Nemitz, E.m and Robarge, W.P.: Estimation of In-Canopy Ammonia Sources and Sinks in a Fertilized Zea mays Field, Environ. Sci. Technol., 44, 1683-1689, 2010.

Bates, R. G. and Pinching, G. D.: Dissociation constant of aqueous ammonia at 0 to $50^{\circ} \mathrm{C}$ from E. m. f. studies of the ammonium salt of a weak acid, Am. Chem. J., 72, 1393-1396, 1950.

Baumgardner, R. E., Lavery Jr., T. F., Rogers, C. M., and Isil, S. S.: Estimates of the Atmospheric Deposition of Sulfur and Nitrogen Species: Clean Air Status and Trends Network, 1990-2000, Environ. Sci. Technol., 36, 2614-2629, 2002.

Bleeker, A., Reinds, G. J., Vermeulen, A. T., de Vries, W., and Erisman, J. W.: Critical loads and resent deposition thresholds of nitrogen and acidity and their exceedances at the level II and level I monitoring plots in Europe, ECN report ECN-C-04-117, Petten, The Netherlands, December 2004.

Bleeker, A., Sutton, M. A., Acherman, B., Alebic-Juretic, A., Aneja, V. P., Ellermann, T., Erisman, J. W., Fowler, D., Fagerli, H., Gauger, T., Harlen, K. S., Hole, L. R., Horvath, L., Mitosinkova, M., Smith, R. I., Tang, Y. S., and van Pul, A.: Linking Ammonia Emission Trends to Measured Concentrations and Deposition of Reduced Nitrogen at different Scales, in: Atmospheric Ammonia, Detecting emission changes and environmental impacts, edited by: Sutton, M. A., Reis, S., and Baker, S. M. H., Springer, 123-180, 2009.

Burkhardt, J., Flechard, C. R., Gresens, F., Mattsson, M., Jongejan, P. A. C., Erisman, J. W., Weidinger, T., Meszaros, R., Nemitz, E., and Sutton, M. A.: Modelling the dynamic chemical interactions of atmospheric ammonia with leaf surface wetness in a managed grassland canopy, Biogeosciences, 6, 67-84, doi:10.5194/bg-667-2009, 2009.

Dasgupta, P. K. and Dong, S.: Solubility of ammonia in liquid water and generation of trace levels of standard gaseous ammonia, Atmos. Environ., 20, 565-570, 1986. 
de Vries, W., Solberg, S., Dobbertin, M., Sterba, H., Laubhahn, D., Reinds, G. J., Nabuurs, G. J., Gundersen, P., and Sutton, M. A.: Ecologically implausible carbon response, Nature, 451, E1-E3, doi:10.1038/nature06579, 2008.

Dolman, A. J., Valentini, R. and Freibauer, A. (eds.): The Continental-Scale Greenhouse Gas Balance of Europe, Springer Ecological Series 203, 390 pp., ISBN: 978-0-387-76568-6. Springer, New York, 2008.

Dorsey, J. R., Duyzer, J. H., Gallagher, M. W., Coe, H., Pilegaard, K., Weststrate, J. H., Jensen, N. O., and Walton, S.: Oxidized nitrogen and ozone interaction with forests. I: Experimental observations and analysis of exchange with Douglas fir, Q. J. Roy. Meteor. Soc., 130, 1941-1955, 2004.

Doskey, P. V., Rao Kotamarthi, V., Fukui, Y., Cook, D. R., Breitbeil, F. W., and Wesely, M. L.: Air-surface exchange of peroxyacetyl nitrate at a grassland site, J. Geophys. Res., 109, D10310, doi:10.1029/2004JD004533, 2004.

Emberson, L., Ashmore, M., Simpson, D., Tuovinen, J.-P., and Cambridge, H.: Modelling and mapping ozone deposition in Europe, Water Air Soil Poll., 130, 577-582, 2001.

EMEP (European Monitoring and Evaluation Programme): Transboundary Acidification, Eutrophication and Ground Level Ozone in Europe in 2007, EMEP Report 1/2009, available at: http:// www.emep.int/publ/reports/2009/status_report_1_2009.pdf, Norwegian Meteorological Institute, 2009.

Erisman, J. W. and Wyers, G. P.: Continuous measurements of surface exchange of $\mathrm{SO}_{2}$ and $\mathrm{NH}_{3}$; implications for their possible interaction in the deposition process, Atmos. Environ., 27A, 1937-1949, 1993.

Erisman, J. W., van Pul, A., and Wyers, P.: Parametrization of surface resistance for the quantification of atmospheric deposition of acidifying pollutants and ozone, Atmos. Environ., 28, 25952607, 1994.

Erisman, J. W., Mennen, M. G., Fowler, D., Flechard, C. R., Spindler, G., Grüner, A., Duyzer, J. H., Ruigrok, W., and Wyers, G. P.: Towards development of a deposition monitoring network for air pollution in Europe, Report $\mathrm{n}^{\circ} 722108015$, RIVM, The Netherlands, http://rivm.openrepository.com/rivm/ bitstream/10029/10432/1/722108015.pdf, 1996.

Erisman, J. W., Vermeulen, A., Hensen, A., Flechard, C., Dammgen, U., Fowler, D., Sutton, M., Grunhage, L., and Tuovinen, J. P.: Monitoring and modelling of biosphere/atmosphere exchange of gases and aerosols in Europe, Environ. Pollut., 133, 403-413, 2005.

Erisman, J. W., Bleeker, A., Galloway, J., and Sutton, M. A.: Reduced nitrogen in ecology and the environment, Environ. Pollut., 150, 140-149, 2007.

Fagerli, H. and Aas, W.: Trends of nitrogen in air and precipitation: Model results and observations at EMEP sites in Europe, 1980 2003, Environ. Pollut., 154, 448-461, 2008.

Famulari, D., Fowler, D., Nemitz, E., Hargreaves, K. J., StoretonWest, R. L., Rutherford, G., Tang, Y. S., Sutton, M. A., and Weston, K. J.: Development of a low-cost system for measuring conditional time-averaged gradients of $\mathrm{SO}_{2}$ and $\mathrm{NH}_{3}$, Environ. Monit. Assess., 161, 11-27, doi:10.1007/s10661-008-07236, 2010

Farquhar, G. D., Firth, P. M., Wetselaar, R., and Weir, B.: On the gaseous exchange of ammonia between leaves and the environment: determination of the ammonia compensation point, Plant
Physiol., 66, 710-714, 1980.

Flechard, C. R.: Turbulent exchange of ammonia above vegetation, Nottingham University, 231 pp., 1998.

Flechard, C. R. and Fowler, D.: Atmospheric ammonia at a moorland site. II: Long term surface/atmosphere micrometeorological flux measurements, Q. J. Roy. Meteor. Soc., 124, 759-791, 1998.

Flechard, C. R., Fowler, D., Sutton, M. A., and Cape, J. N.: A dynamic chemical model of bi-directional ammonia exchange between semi-natural vegetation and the atmosphere, Q. J. Roy. Meteor. Soc., 125, 2611-2641, 1999.

Flechard, C. R., Spirig, C., Neftel, A., and Ammann, C.: The annual ammonia budget of fertilised cut grassland - Part 2: Seasonal variations and compensation point modeling, Biogeosciences, 7 , 537-556, doi:10.5194/bg-7-537-2010, 2010.

Fowler, D., Flechard, C., Skiba, U., Coyle, M., and Cape, J. N.: The atmospheric budget of oxidized nitrogen and its role in ozone formation and deposition, New Phytol., 139, 11-23, 1998.

Fowler, D., Flechard, C., Cape, J. N., Storeton-West, R. L., and Coyle, M.: Measurements of ozone deposition to vegetation quantifying the flux, the stomatal and non-stomatal components, Water Air Soil Poll., 130, 63-74, 2001.

Fowler, D., Pilegaard, K., Sutton, M. A., Ambus, P., Raivonen, M., Duyzer, J., Simpson, D., and 50 others: Atmospheric composition change: Ecosystems-Atmosphere interactions, Atmos. Environ., 43, 5193-5267, 2009.

Gallagher, M. W., Beswick, K. M., Duyzer, J., Westrate, H., Choularton, T. W., and Hummelshøj, P.: Measurements of aerosol fluxes to Speulder forest using a micrometeorological technique, Atmos. Environ., 31, 359-373, 1997.

Gallagher, M. W., Nemitz, E., Dorsey, J. R., Fowler, D., Sutton, M. A., Flynn, M., and Duyzer, J. H.: Measurements and parameterisations of small aerosol deposition velocities to grassland, arable crops, and forests: Influence of surface roughness length on deposition, J. Geophys. Res., 107(D12), 8-1-8-10, doi:10.1029/2001JD000817, 2002.

Galloway, J. N., Aber, J. D., Erisman, J. W., Seitzinger, S. P., Howarth, R. W., Cowling, E. B., and Cosby, B. J.: The Nitrogen Cascade, BioScience, 53(4), 341-356, 2003.

Garland, J. A.: The dry deposition of sulphur dioxide to land and water surfaces, P. R. Soc. London, A354, 245-268, 1977.

Ge, X., Wexler, A. S., and Clegg, S. L.: Atmospheric Amines - Part I: A Review, Atmos. Environ., 45, 524-546, 2011.

Genermont, S. and Cellier, P.: A mechanistic model for estimating ammonia volatilization from slurry applied to bare soil, Agr. Forest Meteorol., 88, 145-167, 1997.

González Benítez, J. M., Cape, J. N., and Heal, M. R.: Gaseous and particulate water-soluble organic and inorganic nitrogen in rural air in southern Scotland, Atmos. Environ., 44, 1506-1514, 2010.

Hicks, B. B.: Dry deposition to forests - On the use of data from clearings, Agr. Forest Meteorol., 136, 214-221, 2006.

Jarvis, P. G.: The interpretation of the variations in leaf water potential and stomatal conductance found in canopies in the field, Philos. T. Roy. Soc., B273, 593-610, 1976.

Joutsenoja, T.: Measurements of aerosol deposition to a cereal crop, in: Measurements and Modelling of Gases and Aerosols to Complex Terrain, NERC Report GR3/7259, edited by: Choularton, T. W., Nat. Environ. Res. Counc., UK, 1992.

Laj, P., Klausen, J., Bilde, M., Plaß-Duelmer, C., Pappalardo, G., Clerbaux, C., Baltensperger, U., and 46 others: Measuring atmo- 
spheric composition change, Atmos. Environ., 43, 5351-5414, 2009.

Lovett, G. M. and Lindberg, S. E.: Atmospheric deposition and canopy interactions of nitrogen in forests, Can. J. Forest Res., 23, 1603-1616, 1993.

Magnani, F., Mencuccini, M., Borghetti, M., Berbigier, P., Berninger, F., Delzon, S., Grelle, A., Hari, P., Jarvis, P. G., Kolari, P., Kowalski, A. S., Lankreijer, H., Law, B. E., Lindroth, A., Loustau, D., Manca, G., Moncrieff, J. B., Rayment, M., Tedeschi, V., Valentini, R., and Grace, J.: The human footprint in the carbon cycle of temperate and boreal forests, Nature, 447, 848-851, 2007.

Massad, R. S., Loubet, B., Tuzet, A., and Cellier, P.: Relationship between ammonia stomatal compensation point and nitrogen metabolism in arable crops: Current status of knowledge and potential modelling approaches, Environ. Pollut., 154, 390-403, 2008.

Massad, R.-S., Nemitz, E., and Sutton, M. A.: Review and parameterisation of bi-directional ammonia exchange between vegetation and the atmosphere, Atmos. Chem. Phys., 10, 10359-10386, doi:10.5194/acp-10-10359-2010, 2010.

Matt, D. R. and Meyers, T. P.: On the use of the inferential technique to estimate dry deposition of $\mathrm{SO}_{2}$, Atmos. Environ., 27A(4), 493-501, 1993.

Meyers, T. P., Finkelstein, P. L., Clarke, J., Ellestad, T. G., and Sims, P.: A multilayer model for inferring dry deposition using standard meteorological measurements, J. Geophys. Res., 103(22), 645-661, 1998.

Milford, C.: Dynamics of atmospheric ammonia exchange with intensively-managed grassland, $\mathrm{PhD}$ Thesis, University of Edinburgh, 230 pp., 2004.

Monteith, J. L. and Unsworth, M. H.: Principles of Environmental Physics, 2nd edition, Edward Arnold, London. 291 pp., 1990.

Nemitz, E., Sutton, M. A., Schjoerring, J. K., Husted, S., and Wyers, G. P.: Resistance modelling of ammonia exchange over oilseed rape, Agr. Forest Meteorol., 105, 405-425, 2000a.

Nemitz, E., Sutton, M. A., Gut, A., San Jose, R., Husted, S., and Schjørring, J. K.: Sources and sinks of ammonia within an oilseed rape canopy, Agr. Forest Meteorol., 105, 385-404, $2000 \mathrm{~b}$.

Nemitz, E., Milford, C., and Sutton, M.A.: A two-layer canopy compensation point model for describing bi-directional biosphere-atmosphere exchange of ammonia, Q. J. Roy. Meteor. Soc., 127, 815-833, 2001.

Nemitz, E., Gallagher, M. W., Duyzer, J. H., and Fowler, D.: Micrometeorological measurements of particle deposition velocities to moorland vegetation, Q. J. Roy. Meteor. Soc., 128A, 2281-2300, 2002.

Nemitz, E., Loubet, B., Lehmann, B. E., Cellier, P., Neftel, A., Jones, S. K., Hensen, A., Ihly, B., Tarakanov, S. V., and Sutton, M. A.: Turbulence characteristics in grassland canopies and implications for tracer transport, Biogeosciences, 6, 1519-1537, doi:10.5194/bg-6-1519-2009, 2009.

Neirynck, J. and Ceulemans, R.: Bidirectional ammonia exchange above a mixed coniferous forest, Environ. Pollut., 154, 424-438, 2008.

Neirynck, J., Kowalski, A. S., Carrara, A.m and Ceulemans, R.: Driving forces for ammonia fluxes over mixedforest subjected to high deposition loads, Atmos. Environ., 39, 5013-5024, 2005.
Neirynck, J., Kowalski, A. S., Carrara, A., Genouw, G., Berghmans, P., and Ceulemans, R.: Fluxes of oxidised and reduced nitrogen above a mixed coniferous forest exposed to various nitrogen emission sources, Environ. Pollut., 149, 31-43, 2007.

Personne, E., Loubet, B., Herrmann, B., Mattsson, M., Schjoerring, J. K., Nemitz, E., Sutton, M. A., and Cellier, P.: SURFATMNH3: a model combining the surface energy balance and bidirectional exchanges of ammonia applied at the field scale, Biogeosciences, 6, 1371-1388, doi:10.5194/bg-6-1371-2009, 2009.

Petroff, A., Mailliat, A., Amielh, M., and Anselmet, F. : Aerosol dry deposition on vegetative canopies. Part I: Review of present knowledge, Atmos. Environ., 42, 3625-3653, 2008a.

Petroff, A., Mailliat, A., Amielh, M., and Anselmet, F.: Aerosol dry deposition on vegetative canopies. Part II: A new modelling approach and applications, Atmos. Environ., 42, 3654-3683, 2008 b.

Pilegaard, K.: Air-soil exchange of $\mathrm{NO}, \mathrm{NO}_{2}$, and $\mathrm{O}_{3}$ in forests, Water Air Soil Poll. Focus, 1, 79-88, 2001.

Pilegaard, K., Skiba, U., Ambus, P., Beier, C., Brüggemann, N., Butterbach-Bahl, K., Dick, J., Dorsey, J., Duyzer, J., Gallagher, M., Gasche, R., Horvath, L., Kitzler, B., Leip, A., Pihlatie, M. K., Rosenkranz, P., Seufert, G., Vesala, T., Westrate, H., and Zechmeister-Boltenstern, S.: Factors controlling regional differences in forest soil emission of nitrogen oxides ( $\mathrm{NO}$ and $\mathrm{N}_{2} \mathrm{O}$ ), Biogeosciences, 3, 651-661, doi:10.5194/bg-3-651-2006, 2006.

Pryor, S. C., Larsen, S. E., Sorensen, L. L., Barthelmie, R. J., Groenholm, T., Kulmala, M., Launiainen, S., Rannik, U., and Vesala, T.: Particle fluxes over forests: Analyses of flux methods and functional dependencies, J. Geophys. Res., 112, D07205, doi:10.1029/2006JD008066, 2007.

Pryor, S. C., Gallagher, M., Sievering, H., Larsen, S. E., Barthelmie, R. J., Birsan, F., Nemitz, E., Rinne, J., Kulmala, M., Groenholm, T., Taipale, R., and Vesala, T.: A review of measurement and modelling results of particle atmosphere-surface exchange, Tellus, 60, 42-75, 2008a.

Pryor, S. C., Larsen, S. E., Sorensen, L. L., and Barthelmie, R. J.: Particle fluxes above forests: Observations, methodological considerations and method comparisons, Environ. Poll., 152, 667678, 2008b.

Ruijgrok, W., Tieben, H., and Eisinga, P.: The dry deposition of particles to a forest canopy: a comparison of model and experimental results, Atmos. Environ., 31, 399-415, 1997.

Schjøerring, J. K., Husted, S., and Mattsson, M.: Physiological parameters controlling plant-atmosphere ammonia exchange, Atmos. Environ., 32, 491-498, 1998.

Schwede, D., Zhang, L., Vet, R., and Lear, G.: An intercomparison of the deposition models used in the CASTNET and CAPMoN networks, Atmos. Environ. 45, 1337-1346, 2011.

Seinfeld, J. H. and Pandis, S. N.: Atmospheric chemistry and physics, From Air Pollution to climate Change, Second edition. John Wiley and Sons Inc., 2006.

Sickles, J. E. and Shadwick, D. S.: Seasonal and regional air quality and atmospheric deposition in the eastern United States, J. Geophys. Res., 112, D17302, doi:10.1029/2006JD008356, 2007.

Simpson, D., Fagerli, H., Jonson, J. E., Tsyro, S., Wind, P., and Tuovinen, J.-P.: Transboundary Acidification, Eutrophication and Ground Level Ozone in Europe. Part I: Unified EMEP Model Description, EMEP Status Report 2003, ISSN 0806-4520, Det Meteorologisk Institutt, Oslo, 2003. 
Simpson, D., Butterbach-Bahl, K., Fagerli, H., Kesik, M., Skiba, U., and Tang, S.: Deposition and Emissions of Reactive Nitrogen over European Forests: A Modelling Study, Atmos. Environ., 40, 5712-5726, 2006a.

Simpson, D., Fagerli, H., Hellsten, S., Knulst, J. C., and Westling, O.: Comparison of modelled and monitored deposition fluxes of sulphur and nitrogen to ICP-forest sites in Europe, Biogeosciences, 3, 337-355, doi:10.5194/bg-3-337-2006, 2006b.

Simpson, D., Gauss, M., Tsyro, S. and Valdebenito, A.: Model Updates, In "Transboundary acidification, eutrophication and ground level ozone in Europe", EMEP Status Report 1/2010, The Norwegian Meteorological Institute, Oslo, Norway, available at: www.emep.int, 105-109, 2010.

Slinn, W. G. N.: Predictions for particle deposition to vegetative canopies, Atmos. Environ., 16, 1785-1794, 1982.

Smith, R. I., Fowler, D., Sutton, M. A., Flechard, C., and Coyle, M.: Regional estimation of pollutant gas deposition in the UK: model description, sensitivity analyses and outputs, Atmos. Environ., 34, 3757-3777, 2000.

Steinbacher, M., Zellweger, C., Schwarzenbach, B., Bugmann, S., Buchmann, S., Ordóñez, C., Prevot, A. S. H., and Hueglin, C.: Nitrogen oxides measurements at rural sites in Switzerland: Bias of conventional measurement techniques, J. Geophys. Res., D11307, doi:10.1029/2006JD007971, 2007.

Sutton, M. A., Fowler, D., Moncrieff, J. B., and Storeton-West, R. L.: The exchange of atmospheric ammonia with vegetated surfaces. II. Fertilized vegetation, Q. J. Roy. Meteor. Soc., 119, 1047-1070, 1993.

Sutton, M. A., Burkhardt, J. K., Guerin, D., Nemitz, E., and Fowler, D.: Development of resistance models to describe measurements of bi-directional ammonia surface atmosphere exchange, Atmos. Environ., 32(3), 473-480, 1998.

Sutton, M. A., Tang, Y. S., Miners, B., and Fowler, D.: A new diffusion denuder system for long-term, regional monitoring of atmospheric ammonia and ammonium, Water Air Soil Poll., Focus 1, 145-156, 2001.

Sutton, M. A., Nemitz, E., Erisman, J.W ., Beier, C., ButterbachBahl, K., Cellier, P., de Vries, W., Cotrufo, F., Skiba, U., Di Marco, C., Jones, S., Laville, P., Soussana, J. F., Loubet, B., Twigg, M., Famulari, D., Whitehead, J., Gallagher, M. W., Neftel, A., Flechard, C. R., Herrmann, B., Calanca, P. L., Schjoerring, J. K., Daemmgen, U., Horvath, L., Tang, Y. S., Emmett, B.A., Tietema, A., Peñuelas, J., Kesik, M., Brueggemann, N., Pilegaard, K., Vesala, T., Campbell, C. L., Olesen, J. E., Dragosits, U., Theobald, M. R., Levy, P., Mobbs, D. C., Milne, R., Viovy, N., Vuichard, N., Smith, J. U., Smith, P., Bergamaschi, P., Fowler, D., and Reis, S.: Challenges in quantifying biosphereatmosphere exchange of nitrogen species, Environ. Pollut. 150, 125-139, 2007.

Sutton, M. A., Simpson, D., Levy, P. E., Smith, R. I., Reis, S., van Oijen, M., and de Vries, W.: Uncertainties in the relationship between atmospheric nitrogen deposition and forest carbon sequestration, Glob. Change Biol., 14, 2057-2063, 2008.

Tang, Y. S., Simmons, I., van Dijk, N., Di Marco, C., Nemitz, E., Dämmgen, U., Gilke, K., Djuricic, V., Vidic, S., Gliha, Z., Borovecki, D., Mitosinkova, M., Hanssen, J. E., Uggerud, T. H., Sanz, M. J., Sanz, P., Chorda, J. V., Flechard, C. R., Fauvel, Y., Ferm, M., Perrino, C., and Sutton, M. A.: European scale application of atmospheric reactive nitrogen measurements in a low-cost approach to infer dry deposition fluxes, Agr. Ecosyst. Environ., 133, 183-195, 2009.

Tang, Y. S., Dämmgen, U., Conrad, J., Djuricic, V., Vidic, S., Flechard, C. R., Mitosinkova, M., Sanz, M. J., Uggerud, T. H., Borovecki, D., Chorda, J. V., Fauvel, Y., Gilke, K., Gliha, Z., Sanz, P., Simmons, I., van Dijk, N., Ferm, M., Nemitz, E., and Sutton, M. A.: Temporal and spatial variability in reactive inorganic trace gas and aerosol concentrations across Europe, Atmos. Chem. Phys. Discuss., in preparation, 2011.

Torseth, K., Semb, A., Schaug, J., Hanssen, J., and Aamlid, D.: Processes affecting deposition of oxidised nitrogen and associated species in the coastal areas of Norway, Atmos. Environ., 34, 207-217, 2000.

Torseth, K., Aas, W., and Solberg, S.: Trends in airborne suplhur and nitrogen compounds in Norway during 1985-1996 in relation to air mass origin, Water Air Soil Poll., 130, 1493-1498, 2001.

Tuovinen, J.-P., Emberson, L., and Simpson, D.: Modelling ozone fluxes to forests for risk assessment: status and prospects, Annals of Forest Science, 66, 401, 401p1-401p14, doi:10.1051/forest/2009024, 2009.

Turnipseed, A. A., Huey, L. G., Nemitz, E., Stickel, R., Higgs, J., Tanner, D. J., Slusher, D. L., Sparks, J. P., Flocke, F., and Guenther, A.: Eddy covariance fluxes of peroxyacetyl nitrates (PANs) and $\mathrm{NO}_{\mathrm{y}}$ to a coniferous forest, J. Geophys. Res., 111, D09304, doi:10.1029/2005JD006631, 2006.

UNECE: Protocol to the 1979 Convention on long-range transboundary air pollution to abate acidification, eutrophication and ground-level ozone. United Nations Economic Commission for Europe, Geneva, http://www.unece.org/env/lrtap/multi_h1.htm, 1999.

van Jaarsveld, J. A.: The Operational Priority Substances model. Description and validation of OPS-Pro 4.1, RIVM report 500045001/2004, RIVM, Bilthoven, the Netherlands, 2004.

Vieno, M.: The use of an Atmospheric Chemistry-Transport Model (FRAME) over the UK and the development of its numerical and physical schemes, PhD thesis, University of Edinburgh, 2005.

Wesely, M. L.: Parameterization of surface resistances to gaseous dry deposition in regional-scale numerical models, Atmos. Environ., 23, 1293-1304, 1989.

Wesely, M. L. and Hicks, B. B.: Some factors that affect the deposition rates of sulfur dioxide and similar gases on vegetation, J. Air Poll. Cont. Assoc., 27, 1110-1116, 1977.

Wesely, M. L. and Hicks, B. B.: A review of the current status of knowledge on dry deposition, Atmos. Environ., 34, 2261-2282, 2000.

Wesely, M. L., Cook, D. R., Hart, R. L., and Speer, R. E.: Measurements and parameterization of particle sulfur deposition over grass, J. Geophys. Res., 90, 2131-2143, 1985.

Wichink Kruit, R. J., van Pul, W. A. J., Sauter, F. J., van den Broek, M., Nemitz, E., Sutton, M. A., Krol, M., and Holtslag, A. A. M.: Modelling the surface-atmosphere exchange of ammonia, Atmos. Environ., 44(7), 945-957, 2010.

Wolfe, G. M., Thornton, J. A., Yatavelli, R. L. N., McKay, M., Goldstein, A. H., LaFranchi, B., Min, K.-E., and Cohen, R. C.: Eddy covariance fluxes of acyl peroxy nitrates (PAN, PPN and MPAN) above a Ponderosa pine forest, Atmos. Chem. Phys., 9, 615-634, doi:10.5194/acp-9-615-2009, 2009.

Wolff, V., Trebs, I., Foken, T., and Meixner, F. X.: Exchange of 
reactive nitrogen compounds: concentrations and fluxes of total ammonium and total nitrate above a spruce canopy, Biogeosciences, 7, 1729-1744, doi:10.5194/bg-7-1729-2010, 2010.

Wu, Y., Brashers, B., Finkelstein, P. L., and Pleim, J. E.: A multiplayer biochemical dry deposition model, I. Model formulation, J. Geophys. Res., 108(D1), 4013, doi:10.1029/2002JD002293, 2003.

Wu, Y., Walker, J., Schwede, D., Peters-Lidard, C., Dennis, R., and Robarge, W.: A new model of bi-directional ammonia exchange between the atmosphere and biosphere: Ammonia stomatal compensation point, Agr. Forest Meteorol., 149, 263-280, 2009.

Wyers, G. P. and Erisman, J. W.: Ammonia exchange over coniferous forest, Atmos. Environ., 32, 441-451, 1998.

Zhang, L., Gong, S., Padro, J., and Barrie, L.: A size-segragated particle dry deposition scheme for an atmospheric aerosol module, Atmos. Environ., 35, 549-560, 2001.

Zhang, L., Brook, J. R., and Vet, R.: A revised parameterization for gaseous dry deposition in air-quality models, Atmos. Chem. Phys., 3, 2067-2082, doi:10.5194/acp-3-2067-2003, 2003.
Zhang, L., Vet, R., Wiebe, A., Mihele, C., Sukloff, B., Chan, E., Moran, M. D., and Iqbal, S.: Characterization of the sizesegregated water-soluble inorganic ions at eight Canadian rural sites, Atmos. Chem. Phys., 8, 7133-7151, doi:10.5194/acp-87133-2008, 2008.

Zhang, L., Vet, R., O'Brien, J. M., Mihele, C., Liang, Z., and Wiebe, A.: Dry deposition of individual nitrogen species at eight Canadian rural sites, J. Geophys. Res., 114, D02301, doi:10.1029/2008JD010640, 2009.

Zhang, L., Wright, L. P., and Asman, W. A.,H.: Bi-directional airsurface exchange of atmospheric ammonia - A review of measurements and a development of a big-leaf model for applications in regional-scale air-quality models. J. Geophys. Res.-Atmos., doi:10.1029/2009JD013589, in press, 2010.

Zimmermann, F., Plessow, K., Queck, R., Bernhofer, C., and Matschullat, J.: Atmospheric $\mathrm{N}$ - and S-fluxes to a spruce forest-Comparison of inferential modelling and the throughfall method, Atmos. Environ., 40, 4782-4796, doi:10.1016/j.atmosenv.2006.03.056, 2006. 